\title{
FENOLOGIA E ESTRUTURA DE UMA FLORESTA SEMIDECÍDUA, EM BOTUCATU-SP: RELAÇÃO COM AS FASES DE DESENVOLVIMENTO SUCESSIONAL
}

\author{
RENATA CRISTINA BATISTA FONSECA \\ Engenheira Florestal
}

Orientador: Prof. Dr. RICARDO RIBEIRO RODRIGUES

\begin{abstract}
Dissertação apresentada à Escola Superior de Agricultura "Luiz de Queiroz", Universidade de São Paulo, para obtenção do título de Mestre em Ciências, Área de Concentração: Ciências Florestais.
\end{abstract}

PIRACICABA

Estado de São Paulo - Brasil

Janeiro - 1998 
Aprovada em: 24.04.98

Comissão Julgadora:

Prof. Dr. Paulo Y. Kageyama

ESALQ/USP

Prof ${ }^{2} r^{2}$ Leonor Patrícia C. Morellato

IB/UNESP-Rio Claro

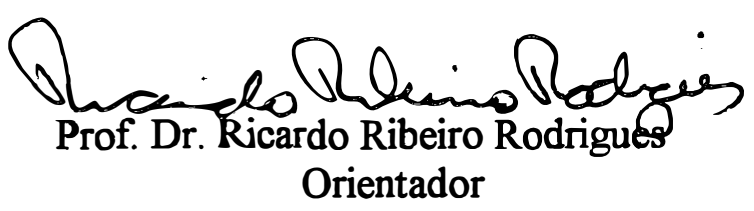


“...e, circunstancialmente, entre posturas mais urgentes, cada um deve sentar-se num banco, plantar bem um dos pés no chão, curvar a espinha, fincar o cotovelo do braço no joelho, e, depois, na altura do queixo, apoiar a cabeça no dorso da mão, e com olhos amenos assistir ao movimento do sol e das chuvas e dos ventos, e com os mesmos olhos amenos assistir à manipulação misteriosa de outras ferramentas que o tempo habilmente emprega em suas transformações, não questionando jamais sobre seus desígnios insondáveis, sinuosos, como não se questionam nos puros planos das planícies as trilhas tortuosas, debaixo dos cascos, traçadas nos pastos pelos rebanhos: que o gado sempre vai ao cocho, o gado sempre vai ao poço..."

(Raduan Nassar) 
Aos meus pais

Walter e Anita, ao meu marido

Marcos Aurélio,

às minhas irmãs

Carla, Inês e Paula,

e à memória de todos aqueles que, de algum lugar, olham por mim, 


\section{AGRADECIMENTOS}

Ao Departamento de Ciências Florestais da ESALQ/USP pela oportunidade da realização do mestrado.

Ao Prof. Dr. Ricardo Ribeiro Rodrigues (Dep. Botânica - ESALQ/USP), pela orientação, apoio e incentivo.

À Prof. Vera Lex Engel (UNESP/Botucatu) pela coorientação e amizade.

Aos Membros da Banca Examinadora Prof. Dr. Paulo Y. Kageyama (ESALQ/USP) e Prof. Dr ${ }^{2}$. Leonor Patrícia C. Morellato (UNESP/Rio Claro) pelas sugestões e enriquecimento do trabalho.

À CAPES pela Bolsa de Mestrado.

À FAPESP pelos recursos de Auxilio à Pesquisa.

Aos meus pais Walter e Anita e ao meu marido Marcos pelo suporte financeiro e emocional.

À Prof'. Drª . Aparecida Mourão Brasil (UNESP/Botucatu) pelo exemplo profissional e amizade.

Ao auxiliar de campo Cassiano Júnior Krouman pela dedicação fundamental nos serviços prestados.

Ao Departamento de Ciências Florestais da Faculdade de Ciências Agronômicas - UNESP/Campus de Botucatu pelo apoio durante o trabalho de campo.

Aos Departamentos de Ciência do Solo e Ciências Ambientais da FCAUNESP/Botucatu pelas análises do solo e dados fornecidos, respectivamente.

Aos colegas Salvador Ribeiro da Silva Filho, Natália M. Ivanauskas e Ana Cristina Kim pelo auxilio na identificação do material botânico. 
Às minhas irmãs Inês e Paula pela solidariedade nos momentos dificeis.

À Renata Evangelista de Oliveira pela amizade, paciência e aprendizado.

Aos amigos Tuia, Sussa, Cobrão e Carmem pelo carinho e convivência.

À Turma de Pós-Graduação e agregados pelo agradável convívio.

E a todos que de alguma forma contribuíram para a concretização deste trabalho e desta etapa de minha vida. 


\section{SUMÁRIO}

LISTA DE FIGURAS...............................................................................ii

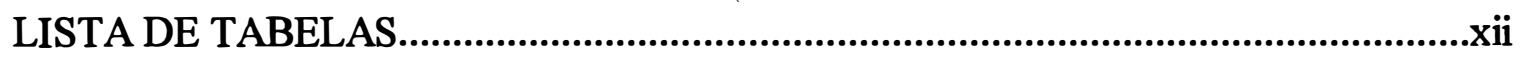

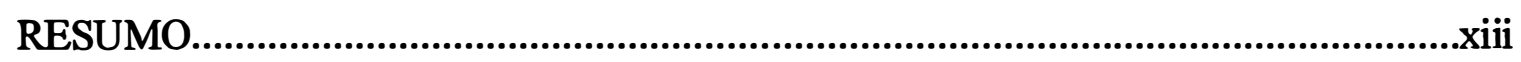

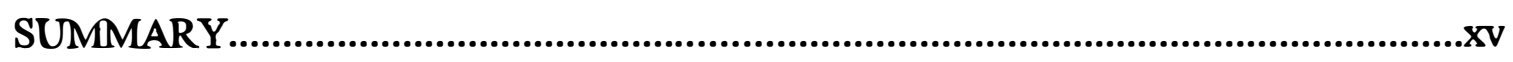

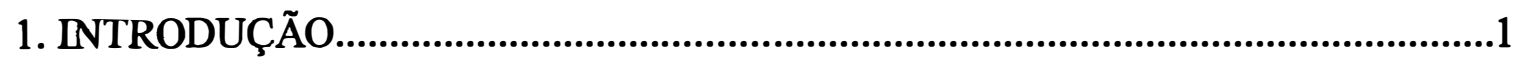

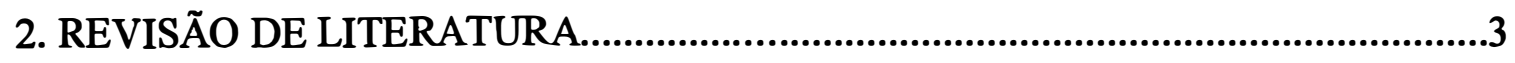

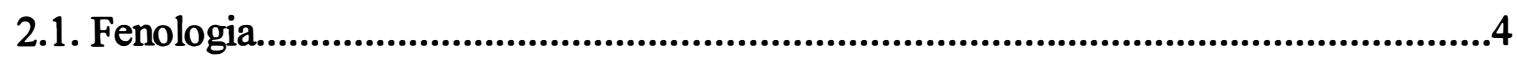

2.2. A floresta tropical e o mosaico florestal................................................................6

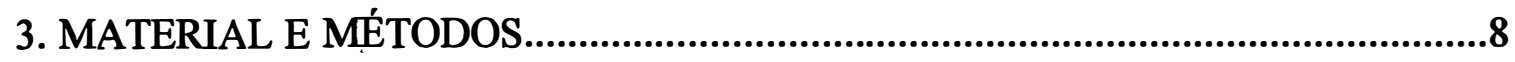

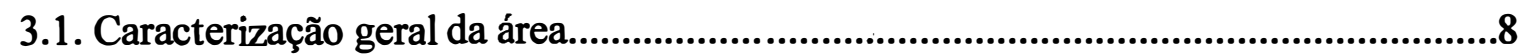

3.1.1. Localização......................................................................................................8

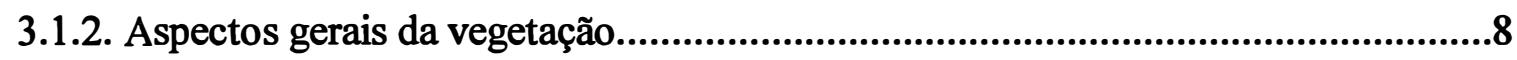

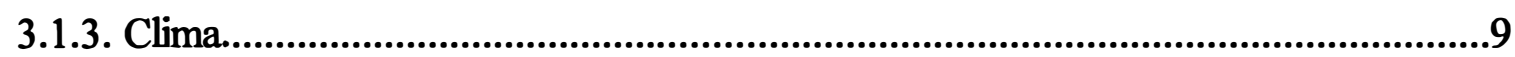

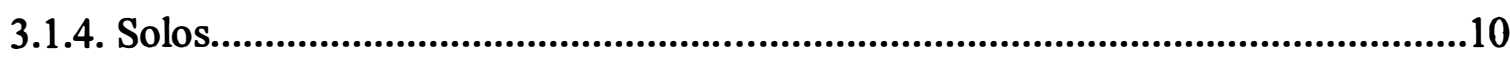

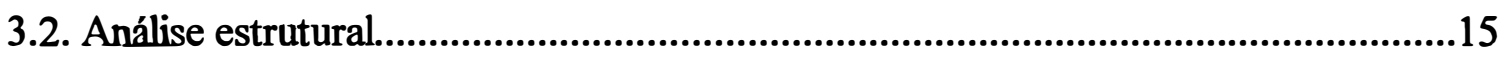

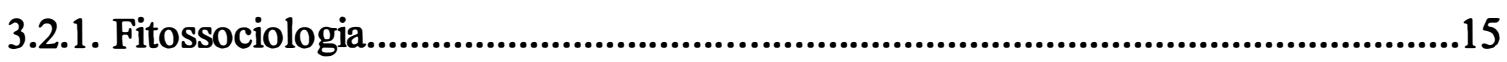

3.2.2. Mosaico florestal......................................................................................16

3.2.2.1. Densidade de Cobertura......................................................................17

3.2.2.2. Altura do Dossel...................................................................................17

3.2.2.3. Grau de Cobertura por Lianas...............................................................17

3.2.2.4. Análise de agrupamento.......................................................................18

3.2.3. Classificação das espécies em grupos ecológicos..............................................18

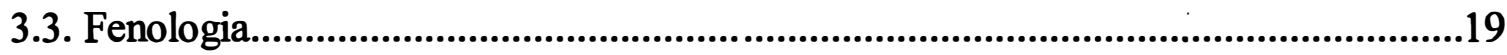

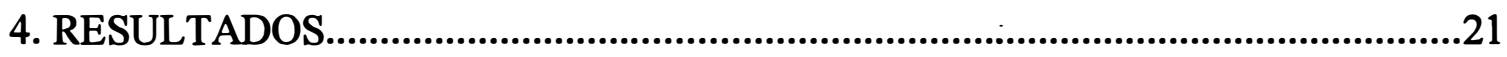

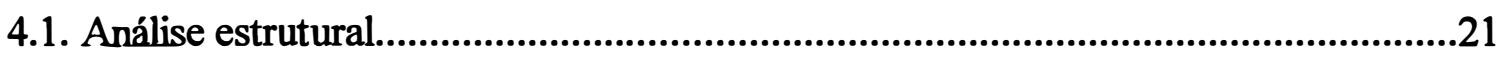

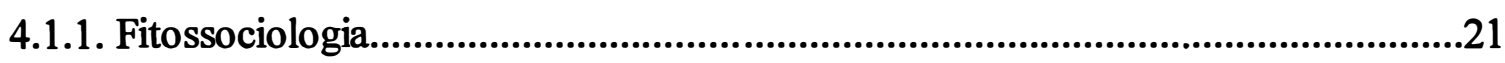

4.1.1.1. Composição florística.......................................................................21

4.1.1.2. Parâmetros gerais.....................................................................................23

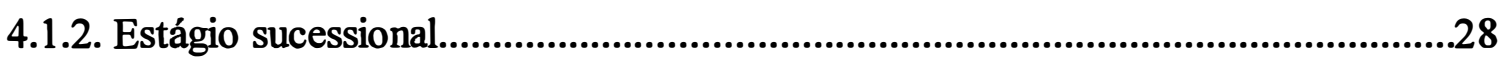

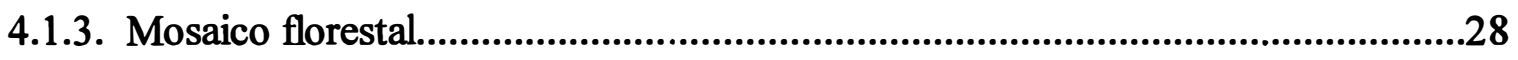

4.1.3.1. Análise de agrupamento .......................................................................28 


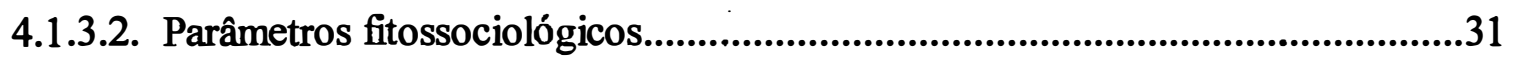

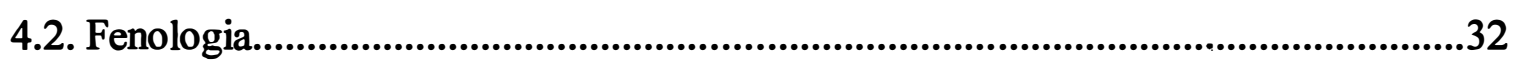

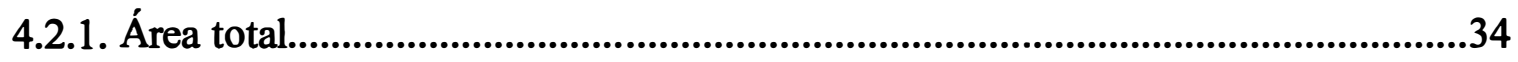

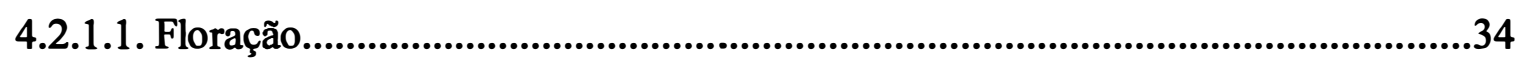

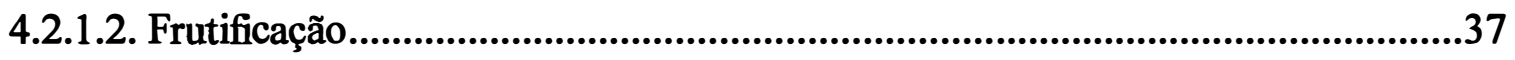

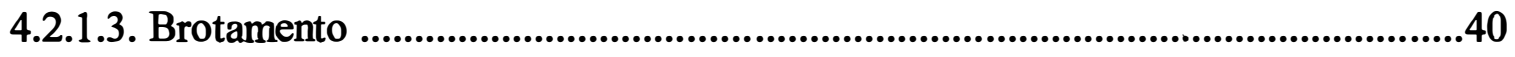

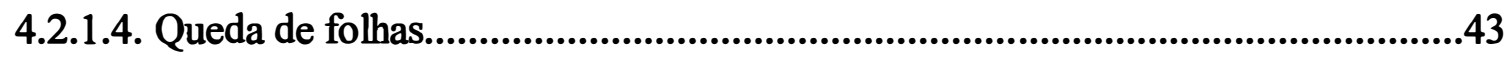

4.2.2. Fases de desenvolvimento do mosaico florestal....................................................44

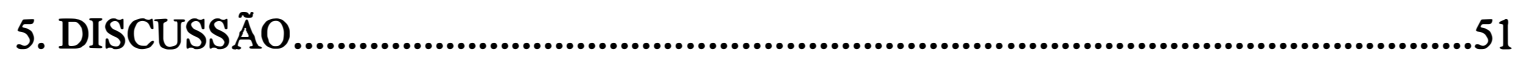

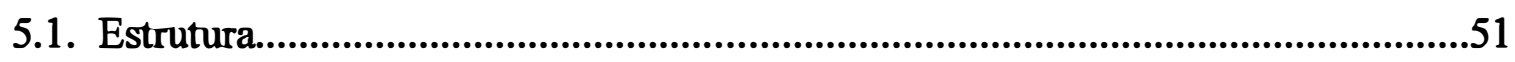

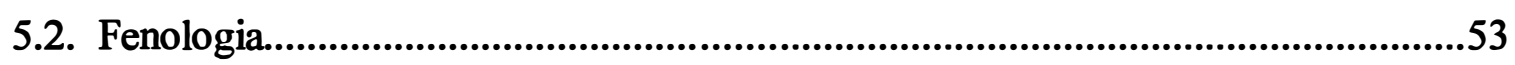

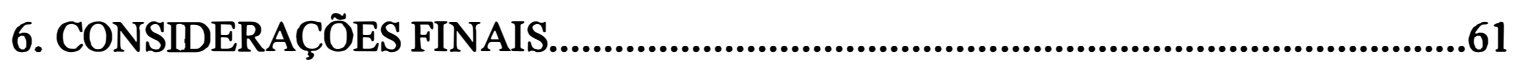

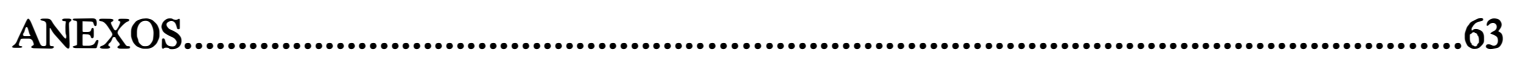

REFERÊNCIAS BIBLIOGRÁFICAS............................................................... 


\section{LISTA DE FIGURAS}

Página

1 Localização da área estudada (Mata da Bica) com sua caracterização topográfica. Fonte: (CARVALHO et al.,1991)......................................... 11

2 Balanço Hídrico do Município de Botucatu (Thorntwaite \& Mather, 1955).

3 Temperatura Média e Precipitação mensais do Município de Botucatu para o ano de 1996. Dados fornecidos pela estação meteorológica do Departamento de Ciências Ambientais da UNESP/Campus de Botucatu....

4 Balanço Hídrico do Município de Botucatu para o ano de 1996 (Thorntwaite \& Mather, 1955). Dados fornecidos pela estação meteorológica do Departamento de Ciências Ambientais da UNESP/Campus de Botucatu..................................................................

5 Esquema de coleta das amostras de solo dentro de uma área de dois hectares no interior da Mata da Bica, Botucatu SP

6 Esquema do gride com as parcelas sorteadas para a realização do levantamento fitossociológico no interior da Mata da Bica, Botucatu-SP...

7 Curva do coletor ou de suficiência amostral para o levantamento fitossociológico realizado em uma área de $100 \mathrm{~m}$ x $200 \mathrm{~m}$ no interior da Mata da Bica, Botucatu-SP.

8 Porcentagem de indivíduos por família encontrado no levantamento fitossociológico realizado no interior da Mata da Bica, Botucatu-SP.........

9 Número de espécies por familia encontrado no levantamento fitossociológico realizado no interior da Mata da Bica, Botucatu-SP.........

10 Porcentagem de Indivíduos por espécie encontrado no levantamento fitossociológico realizado no interior da Mata da Bica, Botucatu-SP.

11 Valor de importância (IVI) para as espécies encontrado no levantamento fitossociológico realizado no interior da Mata da Bica, Botucatu-SP.

12 Número de Indivíduos por Grupo Ecológico encontrado no levantamento fitossociológico realizado no interior da Mata da Bica, BotucatuSP 
13 Valor de Importância (IVI) por Grupo Ecológico encontrado no levantamento fitossociológico realizado no interior da Mata da Bica, Botucatu-SP.

14 Médias de Área Basal, Dominância Média, Cobertura de Lianas, Diâmetro Médio, Número de Indivíduos, Número de Espécies, Altura do Dossel e Porcentagem de Cobertura para cada grupo de parcelas da Mata da Bica, Botucatu-SP. Os valores representam a proporção que cada valor tem do valor máximo encontrado para cada variável, que neste caso foi considerado igual a 1 (um)

15 Padrão de floração das espécies arbóreas (borda de clareira, clareira e dossel) da Mata da Bica, Botucatu-SP, para o ano de 1996; expresso em Porcentagem de Espécies e Porcentagem de Indivíduos em floração por quinzena. As quinzenas estão representadas pelas iniciais de seus meses.

16 Padrão de floração das espécies arbustivas (sub-bosque e sub-dossel) da Mata da Bica, Botucatu-SP, para o ano de 1996; expresso em Porcentagem de Espécies e Porcentagem de Indivíduos em floração por quinzena. As quinzenas estão representadas pelas iniciais de seus meses.

17 Padrão de floração das espécies de lianas da Mata da Bica, Botucatu-SP, para o ano de 1996; expresso em Porcentagem de Espécies e Porcentagem de Parcelas com a presença de lianas em floração por quinzena. As quinzenas estão representadas pelas iniciais de seus meses.

18 Padrão de frutificação das espécies arbóreas (borda de clareira, clareira e dossel) da Mata da Bica, Botucatu-SP, para o ano de 1996; expresso em Porcentagem de Espécies e Porcentagem de Indivíduos em floração por quinzena. As quinzenas estão representadas pelas iniciais de seus meses 
19 Padrão de frutificação das espécies arbustivas (sub-bosque e sub-dossel) da Mata da Bica, Botucatu-SP, para o ano de 1996; expresso em Porcentagem de Espécies e Porcentagem de Indivíduos em floração por quinzena. As quinzenas estão representadas pelas iniciais de seus meses.

20 Padrão de frutificação das espécies de lianas da Mata da Bica, BotucatuSP, para o ano de 1996; expresso em Porcentagem de Espécies e Porcentagem de Parcelas com a presença de lianas em floração por época quinzena. As quinzenas estão representadas pelas iniciais de seus meses.

21 Padrão de floração das espécies arbóreas dentro de cada grupo de parcelas na Mata da Bica, Botucatu-SP, para o ano de 1996; expresso em Número de Indivíduos em floração por quinzena. As quinzenas estão representadas pelas iniciais de seus meses.

22 Padrão de floração das espécies arbustivas dentro de cada grupo de parcelas na Mata da Bica, Botucatu-SP, para o ano de 1996; expresso em Número de Indivíduos em floração por quinzena. As quinzenas estão representadas pelas iniciais de seus meses.

23 Padrão de floração das espécies de lianas dentro de cada grupo de parcelas na Mata da Bica, Botucatu-SP, para o ano de 1996; expresso em Número de Indivíduos em floração por por quinzena. As quinzenas estão representadas pelas iniciais de seus meses

24 Padrạo de frutificação das espécies de lianas dentro de cada grupo de parcelas na Mata da Bica, Botucatu-SP, para o ano de 1996; expresso em Número de Indivíduos em floração por por quinzena. As quinzenas estão representadas pelas iniciais de seus meses

25 Padrão de floração dą ç̣łpunidade (árvores, arbustos e lianas) para cada grupo de parcelas na Mata da Bica, Botucatu-SP, para o ano de 1996; expresso em Número de Indivíduos (árvores e arbustos) e Número de Parcelas (lianas) por quinzena. As quinzenas estão representadas pelas iniciais de seus meses 
26 Padrão de frutificação da comunidade (árvores, arbustos e lianas) para cada grupo de parcelas na Mata da Bica, Botucatu-SP, para o ano de 1996; expresso em Número de Indivíduos (árvores e arbustos) e Número de Parcelas (lianas) por quinzena. As quinzenas estão representadas pelas

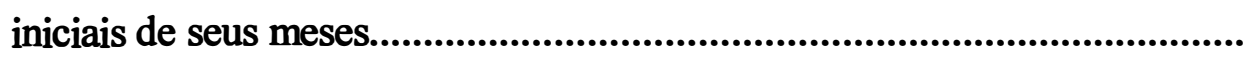




\section{LISTA DE TABELAS}

Página

1 Lista de espécies arbóreas e arbustivas encontradas na Mata da Bica, em Botucatu-SP, ordenadas por familia com respectivos nomes vulgares, grupos ecológicos (G.E.) e posicionamento (P): mosaico florestal(horizontal) e perfil estrutural (vertical).....................................

2 Parâmetros fitossociológicos para a área total e para cada grupo de parcelas na Mata da Bica, Botucatu-SP..................................................

3 Lista de espécies de lianas observadas na Mata da Bica, em Botucatu$\mathrm{SP}$, ordenadas por familia com respectivos nomes vulgares atribuídos pela própria equipe de campo............................................................ 


\title{
FENOLOGIA E ESTRUTURA DE UMA FLORESTA SEMIDECÍDUA, EM BOTUCATU-SP: RELAÇÃO COM AS FASES DE DESENVOLVIMENTO SUCESSIONAL
}

\author{
Autora: Renata Cristina Batista Fonseca \\ Orientador: Prof. Dr. Ricardo Ribeiro Rodrigues
}

\section{RESUMO}

O presente trabalho tem como objetivo estudar a fenologia de uma comunidade florestal (árvores, arbustos e lianas), em um trecho de Floresta Estacional Semidecidual no município de Botucatu-SP (latitude: 22 ${ }^{\circ} 49$ 'S, longitude: $48^{\circ} 23^{\prime} \mathrm{W}$ e altitude 577) baseando-se na análise estrutural do mesmo, e verificar se o comportamento fenológico da comunidade varia de acordo com as diferentes fases do mosaico sucessional. Desta forma, foram alocadas 200 parcelas de $10 \mathrm{~m}$ x $10 \mathrm{~m}$ formando um gride de $200 \mathrm{~m}$ x $100 \mathrm{~m}$ no centro do fragmento, onde procedeu-se a análise estrutural e o estudo fenológico. Para separar a área de estudo em unidades que apresentassem as diferentes fases de desenvolvimento do mosaico florestal (clareira, construção e madura) foi realizada uma análise de agrupamento baseada nas características estruturais de cada parcela. Além dos parâmetros normalmente utilizados em levantamentos fitossociológicos, outros parâmetros, como densidade de cobertura, altura do dossel e cobertura por lianas, foram estimados com o objetivo de caracterizar ainda melhor as diferenças estruturais entre as parcelas. Para o estudo fenológico foram realizadas observações quinzenais de todas as espécies arbóreas e arbustivas amostradas no levantamento fitossociológico. Para as espécies com o número de indivíduos superior a 10, foram sorteados apenas 10 indivíduos para compor a amostra. No caso das lianas, devido a dificuldade de isolar indivíduos, as observações foram realizadas no nível de parcelas onde foram anotadas todas as espécies que floresceram e/ou frutificaram em cada parcela. Foram definidas as épocas de floração, frutificação, queda de folhas e brotamento para árvores e arbustos, e floração e frutificação para lianas. Foram comparados os padrões fenológicos entre as 
formas de vida, e as fases de desenvolvimento do mosaico florestal. A comunidade florestal estudada apresentou padrões sazonais para as fenofases queda e folhas, brotamento, floração e frutificação. $\mathrm{O}$ período de maior diversidade (porcentagem de espécies) na floração e frutificação nem sempre correspondeu ao período de maior produção (porcentagem de indivíduos) de flores e frutos na comunidade. Variações ocorreram no comportamento fenológico das espécies de acordo com a estratificação (sub-bosque, sub-dossel e dossel) e distribuição no mosaico florestal (clareira e borda de clareira). Foi observada uma assincronia dos períodos de maior floração e frutificação entre árvores, arbustos e lianas. $\mathrm{O}$ comportamento fenológico da comunidade apresentou variações de acordo com as fases de desenvolvimento do mosaico florestal. A influência das lianas no padrão de floração e frutificação foi maior na comunidade referente às fases de clareira e construção. Nas áreas em fase madura o padrão de floração foi determinado pelas espécies arbustivas, ou melhor de sub-dossel, enquanto que o padrão de frutificação foi determinado por árvores e arbustos. Os resultados obtidos neste trabalho reforçam a importância das lianas na manutenção de recursos para polinizadores e dispersores em períodos críticos. Além disso, evidencia a contribuição dos arbustos na oferta de recursos para a fauna principalmente nas áreas maduras, onde ocorrem com maior freqüência. 


\title{
PHENOLOGY AND STRUCTURE OF A SEMI-DECIDUOUS FOREST IN BOTUCATU (SÃO PAULO STATE, BRAZIL) WITH RELATION TO SUCCESSIONAL DEVELOPMENT PHASES
}

\author{
Author: Renata Cristina Batista Fonseca \\ Advisor: Dr. Ricardo Ribeiro Rodrigues
}

\section{SUMMARY}

The phenology of a semi-deciduous forest community (trees, shrubs, and lianas) was evaluated with relation to the respective phase of mosaic development. A grid measuring $200 \mathrm{~m} \mathrm{X} \mathrm{100m} \mathrm{was} \mathrm{established} \mathrm{in} \mathrm{the} \mathrm{center} \mathrm{of} \mathrm{a} \mathrm{forest} \mathrm{fragment} \mathrm{in} \mathrm{Botucatu}$ County, São Paulo State $\left(22^{\circ} 49^{\prime} \mathrm{S}, 4^{\circ} 23^{\prime} \mathrm{W}\right)$ at an elevation of 577 meters. From this, 200 "10mX10m" plots were delineated. The phase of mosaic development (gap, construction, or mature) in an area was defined using a cluster analysis of the plots. Criteria used to define a plot included the usual phytosociological parameters and three additional structural characteristics: density of canopy cover, average canopy height, and degree of liana colonization. The phenology of all tree, shrub, and liana species sampled in the plots was observed every two weeks. For tree and shrub species with large populations, ten individuals were randomly sampled. Lianas, usually very difficult to identify as single individuals, were described as one individual-per-plot-per-species. The time of flowering, time of fruiting, leaf-fall, and leaf-production were recorded for trees and shrubs. Observations for lianas were only made in terms of flowering and fruiting. Phenological patterns were analyzed across species and phase of mosaic development. The forest community studied showed definite seasonal patterns of leaf-fall, leaf 
production, flowering, and fruiting. Periods of high flower and fruit diversity (in terms of total number of species) were not always correlated with periods of high production (in terms of total number of individuals). Phenological patterns varied according to stratum (sub-bosque, sub-dossel, and dossel) and location within the forest (gap and gapedge). A high asynchrony in peaks of flowering and fruiting was observed for trees, shrubs, and lianas. Phenological patterns were also dependent on phase of mosaic development. Flowering and fruiting in lianas was greater for "gap" and "construction" phases. In "mature" phase areas, flowering patterns were determined by shrub species (sub-dossel), while fruiting patterns were dominated by both shrubs and trees. The present research suggests that lianas are important contributors of flowers and fruits during critical periods and that shrubs play a critical role in "mature" phase areas. 


\section{INTRODUÇÃO}

O manejo efetivo de ecossistemas tropicais para a preservação, conservação e obtenção de recursos florestais deve estar fundamentado em informações biológicas básicas como estudos em fenologia, biologia floral e reprodutiva das espécies, dinâmica de populações, biologia de sementes, regeneração e genética de populações (Bawa \& Krugman, 1993). Neste contexto, o conhecimento do comportamento fenológico da comunidade torna-se fundamental em qualquer plano de manejo florestal (Fournier, 1976).

A fenologia contribui ainda para o entendimento da regeneração e reprodução das plantas, das interações com a fauna para polinização e dispersão, da evolução da história de vida dos animais que dependem dessas plantas para alimentação (herbívoros, polinizadores e dispersores) e da organização temporal dos recursos dentro dos ecossistemas. $\mathrm{O}$ entendimento destes fatores é necessário para se conhecer o funcionamento dos ecossistemas e a evolução de comunidades (Newstron et al., 1993; Sarmiento \& Monasterio, 1983).

Apesar de sua grande importância, estudos de fenologia em ambientes florestais tropicais são escassos e fragmentados (Foumier \& Charpantier, 1975), além de terem poucos estudos de longo prazo, abordando diferentes formas de vida (árvores, arbustos, lianas, epífitas, ervas), em uma determinada região tropical (Morellato, 1991).

No Brasil, esses estudos fenológicos são ainda mais raros e tratam principalmente da fenologia de espécies arbóreas isoladas (Araújo, 1970; Alencar et al., 1979; Jackson, 1978; Matthes, 1980; Morellato \& Leitão Filho, 1990; Morellato et al., 1989; Morellato et al., 1990). Muito poucos trabalhos englobam a fenologia de árvores, arbustos e lianas de uma comunidade florestal, analisando os padrões fenológicos do ponto de vista das síndromes de polinização e dispersão das espécies (Morellato, 1991; Morellato \& Leitão Filho, 1996).

Em geral, os estudos fenológicos são realizados através de observações em trilhas que margeiam os remanescentes florestais, não se sabendo ao certo se o padrão encontrado nestas áreas corresponde ao que verdadeiramente ocorre no interior da mata, 
já que a estrutura e dinâmica das áreas de borda são muito diferentes do interior da floresta.

Além disso, muitos desses estudos não possuem uma área amostral definida. Normalmente são escolhidos alguns indivíduos de algumas espécies e depois é traçado um padrão fenológico para cada espécie. $O$ padrão para a comunidade é traçado com base na somatória dos padrões das espécies selecionadas.

Diversos estudos ecológicos mostram que a floresta tropical não é homogênea quanto à sua estrutura e função. Ao contrário, é considerada como um mosaico composto por pequenas áreas em diferentes graus de desenvolvimento estrutural, e cujas características dependem do regime de distúrbio a que esta floresta está submetida, ou seja, à freqüência, grau e natureza da formação de clareiras no dossel (Budowski, 1965; Denslow,, 1987; Martinez-Ramos, 1985 e Whitmore, 1978, 1990). Como cada uma dessas unidades é dominada por espécies com estratégias regenerativas diferentes e com diferentes ciclos de vida, é de se esperar que o padrão fenológico varie nas diferentes unidades que compõem o mosaico florestal.

Levantamentos fitossociológicos realizados em florestas tropicais vêm sendo realizados com o intuito de retratar a estrutura de determinados trechos de mata e de compará-los com outros trechos em diferentes condições de solo, clima, estádio sucessional, e etc.; mas raros são os que retratam as variações que ocorrem nas diferentes fases de desenvolvimento do mosaico florestal.

No estado de São Paulo, como nos demais estados brasileiros, as formações florestais são ainda pouco conhecidas quanto a composição florística e principalmente quanto aos aspectos da dinâmica florestal. Os estudos fitossociológicos desenvolvidos deixam muitas vezes de amostrar trechos perturbados dessas formações (Gandolfi et al., 1995).

O presente trabalho tem como objetivo estudar a fenologia e estrutura de uma comunidade florestal (árvores, arbustos e lianas), em um trecho de Floresta Estacional Semidecidual e analisar o comportamento fenológico da comunidade de acordo com as fases de desenvolvimento do mosaico florestal. 


\section{REVISÃO DE LITERATURA}

A cobertura florestal nativa do Estado de São Paulo ocupa aproximadamente 7\% de sua área original (Fundação SOS Mata Atlântica \& Instituto Nacional de Pesquisas Espaciais, 1992), concentrando-se principalmente nas encostas acidentadas e de difícil acesso da Serra do Mar.

O processo de substituição da vegetação nativa, especialmente da cobertura florestal, pela expansão das fronteiras agrícola e pecuária e das malhas urbanas, assim como o extrativismo indiscriminado, ocasionou no interior do Estado de São Paulo a fragmentação dos ecossistemas florestais, condicionando-os a pequenas manchas ou fragmentos isolados. Como conseqüência, o efeito de borda e o grau de isolamento entre os fragmentos foram aumentados (Viana, 1990; Viana et al., 1992).

Os poucos remanescentes preservados da formação florestal característica do interior paulista são portanto de grande valor ecológico e taxonômico, funcionando como uma coleção viva de espécies representativas da flora local e de sua diversidade genética, bem como banco de informações acerca da estrutura e funcionamento deste tipo de ecossistema (Ortega \& Engel, 1992).

As práticas de manejo de florestas tropicais têm como objetivos: (a) corte seletivo e regeneração de espécies comercialmente importantes com o mínimo de impacto sobre as espécies menos valiosas; (b) variação da composição de espécies com o objetivo de aumentar a densidade e freqüência das mais valiosas; (c) recuperação de áreas degradadas com espécies exóticas ou nativas; (d) conservação e recuperação, a curto e a longo prazo da biota original. Desta forma, o manejo responsável exige conhecimento sobre a biologia floral e reprodutiva e sobre a estrutura genética das espécies manejadas. $\mathrm{O}$ fato das relações entre o ciclo de vida das árvores de florestas tropicais estarem ligadas à ecologia de outras espécies de plantas e animais da comunidade torna dificil desenvolver estratégias de manejo com base no conhecimento isolado de espécies (Bawa \& Krugman, 1993). 


\subsection{Fenologia}

O termo fenologia pode ser definido como o estudo da ocorrência de eventos biológicos repetitivos e das causas de sua ocorrência, em relação às forças seletivas bióticas e abióticas e, também, da interrelação entre as fases caracterizadas por estes eventos, numa mesma e em diferentes espécies (Lieth, 1974).

A observação fenológica, obtida de forma sistemática, reúne informações sobre o estabelecimento de espécies, período de crescimento, período de reprodução (floração e frutificação) e disponibilidade de recursos para polinizadores e dispersores (Frankie et al., 1974; Morellato \& Leitão Filho, 1990)

Os eventos fenológicos mais importantes correspondem às fases de botão floral, floração, frutos verdes ou maduros, queda de folhas e brotamento (Fournier, 1974).

Para estudos em fenologia, o intervalo entre as observações de uma espécie ou de uma comunidade pode ser semanal (Morellato, 1991) ou quinzenal (Morellato \& Leitão Filho, 1990; Morellato et al., 1989). Alguns trabalhos utilizam observações mensais (Alencar et al., 1979; Dutra, 1987; Lima Júnior \& Alencar, 1992; Ramalho \& Marangon, 1989). Intervalos superiores a estes são desaconselháveis pois corre-se o risco de não se observar eventos que se manifestam em curto espaço de tempo (Amaral, 1993).

A maior parte dos estudos realizados em florestas tropicais conduz a evidências que a sazonalidade e os ritmos periódicos de crescimento não podem ser atribuídos exclusivamente a um controle endógeno, mas também às condições ambientais externas. Fatores genéticos internos deterninando a existência de periodicidade em plantas ropicais foram sugeridos, porém fatores ambientais é que regularizariam este ritmo interno e determinariam as épocas de crescimento e reprodução (Morellato et al., 1989).

Para Mantovani et al. (1989) o período de floração poderia ser uma adaptação das espécies à dispersão de seus diásporos, a qual seria otimizada quando agentes dispersores tivessem ótimas condições para agirem. Reich (1995) aborda o aumento da concentração de $\mathrm{CO}_{2}$ e da temperatura como fatores que podem influenciar no desenvolvimento foliar nas florestas tropicais.

Wright \& Calderon (1995) testaram três hipóteses para explicar a época de florescimento na flora da Ilha do Barro Colorado, no Panamá. A hipótese de algumas plantas florescerem na mesma época pelo fato de compartilharem dos mesmos 
polinizadores foi rejeitada. Outra hipótese considerando o "stress" hídrico como causa do florescimento na estação úmida das espécies vindas de habitats secos e que apresentam dificuldades de absorverem água do solo também foi rejeitada. Entretanto, as médias e variâncias da época de florescimento foi similar entre alguns gêneros e familias. Estes dados indicam a existência de um forte padrão filogenético determinando a época de florescimento.

Desta forma, dados climáticos não são suficientes para explicar a fenologia das árvores em relação a sazonalidade das florestas tropicais. Mudanças sazonais na quantidade de água disponível no solo e capacidade de armazenamento de água das espécies devem ser considerados. (Borchet, 1994). O clima sazonal também influi na ocorrência de agentes polinizadores, agentes dispersores, predadores e competidores (Morellato et al., 1989). Além disso, há uma grande variação nos padrões fenológicos de acordo com o sítio, ano, espécies e indivíduos (Carabias-Lillo \& Guevara-Sada, 1985).

Outro fator importante na determinação do padrão fenológico da comunidade é a sucessão secundária (Carabias-Lillo \& Sada, 1985). Os autores consideram a variação da composição florística como causa da variação do padrão fenológico das comunidades em diferentes estádios sucessionais.

No nível de comunidade, o florescimento é muitas vezes seqüencial se a polinização for efetuada por alguns grupos de polinizadores. Estes se transferem gradualmente de uma espécie para outra quando os recursos florais de uma declina e da outra aumenta. Este fato tem sido observado em florestas tropicais tanto na América Central como no Sudeste Asiático (Bawa \& Krugman, 1993).

As oscilações de florescimento das espécies de florestas tropicais têm implicações no manejo. Algumas espécies com florescimento seqüencial podem servir aos polinizadores em períodos críticos. Assim, a remoção de tais espécies desta comunidade vai influenciar nos grupos de polinizadores e, consequentemente, nos grupos de plantas que dependem destes. Algumas espécies podem depender de certos frugívoros para a dispersão de sementes e, por outro lado, estes animais podem depender de outras espécies durante períodos de baixa produção de frutos (Bawa \& Krugman, 1993).

$\mathrm{O}$ número de trabalhos abordando a fenologia de florestas tropicais tem aumentado gradativamente nos últimos anos. São poucos os trabalhos que englobam outras sinúsias que não árvores (Morellato, 1991). Na Costa Rica foram realizados estudos sobre a fenologia de árvores, arbustos e lianas em diferentes tipos de vegetação (Franckie et al.,1974; Koptur et al., 1988; Opler et al., 1976, 1980, 1991). No Panamá 
alguns estudos abordaram praticamente toda a flora da Ilha do Barro Colorado (Croat, 1975; Putz \& Windsor, 1987). O padrão fenológico de árvores e arbustos foi estudado na Estação Biológica "Los Tuxtlas", no México. Outro trabalho realizado no mesmo local incluiu lianas e árvores anemocóricas (Carabias-Lillo \& Guevara-Sada, 1985; IbarraMarínquez et al., 1991). Nas Filipinas, o padrão fenológico de árvores, arbustos e lianas foi também estudado (Heideman, 1989).

$\mathrm{Na}$ Costa Rica foi observado um pico de florescimento para lianas no início da estação seca e para árvores no final desta estação (Franckie et al., 1974; Opler et al., 1980, 1991). No Panamá foi encontrado dois picos diferentes de florescimento para lianas e árvores (Croat,1975; Putz \& Windsor, 1987). Carabias-Lillo \& Sada (1985), trabalhando no México, verificaram que as espécies arbóreas tendem a florescer durante a estação seca, enquanto os arbustos tendem a florescer no início da estação chuvosa.

No Brasil um trabalho realizado na Reserva de Santa Genebra em Campinas SP concluiu que o padrão de florescimento e frutificação de árvores, arbustos e lianas são totalmente diferentes, e que existe uma assincronia no florescimento e frutificação entre trepadeiras e espécies arborescentes (Morellato \& Leitão Filho, 1996).

Este último trabalho ainda mostra que os padrões de frutificação de árvores e trepadeiras anemocóricas são semelhantes, mas que espécies arbóreas e trepadeiras zoocóricas apresentam padrões fenológicos diferentes. $\mathrm{O}$ padrão fenológico para trepadeiras, geralmente complementar para aquele apresentado por árvores, mantém constante a oferta de recursos ao longo do ano.

\subsection{A floresta tropical e o mosaico florestal}

A floresta tropical pode ser encarada como um grande mosaico formado por "retalhos" de diferentes idades, tamanhos e composição de espécies. Este fato está relacionado à discussão sobre a sucessão secundária, já que este mosaico conteria trechos em diferentes estágios sucessionais, sendo altamente importante para entender a diversidade e estrutura das florestas tropicais e, portanto, sua conservação (Kageyama, 1987).

O dossel de uma floresta muda à medida que as árvores crescem e morrem e outras a substituem. Este equilíbrio dinâmico pode ser subdividido em três fases de crescimento/desenvolvimento florestal: a fase de clareira, a fase de construção e a fase 
madura. A fase de clareira, contendo mudas e árvores jovens, passa à medida que cresce, pela fase de construção, que é uma floresta jovem e que amadurece através de um crescimento contínuo de suas árvores constituintes (Whitmore, 1978, 1990).

O termo silvigênese refere-se ao processo pelo qual a arquitetura da floresta é construída, ou seja, ao processo de "fabricação da floresta" (Hallè et al., 1978). Estuda o ciclo de desenvolvimento e regeneração do mosaico sucessional. Uma eco-unidade ou unidade de regeneração é uma unidade de vegetação que começou a crescer numa determinada superficie num mesmo momento no tempo, e correspondem a peças do mosaico florestal definidas como unidades coetâneas e ecologicamente uniformes. Desta forma, cada eco-unidade fornece nichos diferentes para diferentes espécies (Oldeman, 1983).

A seqüência de desenvolvimento de uma eco-unidade passa por de uma fase de reorganização, uma fase de desenvolvimento, uma fase biostática ou em equilíbrio dinâmico e uma fase de degradação. A substituição das árvores leva à morte da ecounidade em questão e a sua substituição por uma ou mais eco-unidades. Assim, o desenvolvimento das eco-unidades é tratado como um subprocesso do desenvolvimento da unidade silvática ou mosaico florestal (Oldeman 1989,1990).

As eco-unidades podem então ser consideradas como "peças" que constróem o mosaico florestal. $\mathrm{O}$ "evento zero" que marca o aparecimento de uma eco-unidade nova na floresta é a formação de uma clareira. A medida que ocorre a cicatrização desta clareira por árvores que iniciam uma fase de crescimento ativo, a eco-unidade passa por uma fase de desenvolvimento até chegar à fase de maturidade arquitetural, onde o dossel está totalmente regenerado e em seu grau máximo de estruturação. 


\section{MATERIAL E MÉTODOS}

\subsection{Caracterização geral da área}

\subsubsection{Localização}

O presente trabalho foi desenvolvido em uma área pertencente à Universidade Estadual Paulista - UNESP, Faculdade de Ciências Agronômicas, Campus de Botucatu, localizada na Fazenda Edgardia (latitude: $22^{\circ} 49^{\prime} \mathrm{S}$, longitude: $48^{\circ} 23^{\prime} \mathrm{W}$ e altitude de 577 m), situada no município de Botucatu, Estado de São Paulo.

\subsubsection{Aspectos gerais da vegetação}

As florestas da Fazenda Edgardia enquadram-se na unidade fitogeográfica denominada Floresta Estacional Semidecidual (Instituto Brasileiro de Geografia e Estatística, 1991) ou no tipo Floresta Mesófila Semidecídua (Rizzini, 1979), ocorrendo na área de transição da Depressão Periférica para Cuesta Basáltica. Na classificação de Dubois (1970), correspondem às Matas Latifoliadas Tropicais e Subtropicais do Brasil Meridional, Distrito Norte Paranaense e Estado de São Paulo e Minas Gerais.

A Fazenda conta com aproximadamente 1000 ha de remanescentes florestais pouco alterados e áreas que passaram por vários níveis de perturbações antrópicas, além de ambientes de várzea e cerrado, ocupando o "front" oriental da "cuesta" de Botucatu, num gradiente latitudinal variando de 500 a 800 m. Destes 1000 ha, cerca de $20 \%$ são de mata primária, que correspondem ao trecho escarpado da encosta, cujo acesso é difícil. Os demais trechos variam de mata primária alterada por extração seletiva de madeira, mata secundária tardia alta (cerca de 100 anos de idade), matas alteradas por incêndios, 
matas secundárias e capoeiras jovens ou degradadas pela passagem do fogo, além das matas ciliares (Ortega \& Engel, 1992).

Foi escolhido para a realização deste estudo um trecho de um fragmento de floresta secundária tardia alta denominado "Mata da Bica" (Figura 1).

Conforme histórico, esta área sofreu desmatamento sendo deixados poucos indivíduos para estoque de madeira e ou sombreamento de culturas. Atualmente a mata apresenta-se estruturalmente recuperada, apresentado dossel de até $30 \mathrm{~m}$ e áreas com grandes clareiras dominadas por lianas e bambusoides de gênero Chusquea (Silva Filho \& Engel, 1993).

\subsubsection{Clima}

O clima da região de Botucatu, baseado na classificação de Köeppen, é do tipo Cfa : Clima Temperado (Mesotérmico), região constantemente úmida, tendo quatro ou mais meses com temperaturas médias superior a $22^{\circ} \mathrm{C}$ (Setzer, 1966).

A precipitação anual média da região é de $1300 \mathrm{~mm}$, oscilando entre $650 \mathrm{~mm}$ e $1850 \mathrm{~mm}$, respectivamente, para os anos mais secos e mais úmidos. A estação chuvosa vai de novembro a fevereiro com média de $1100 \mathrm{~mm}$ contra cerca de $250 \mathrm{~mm}$ na estação seca, de julho a novembro (Ortega \& Engel, 1992).

De acordo com o Balanço Hídrico do Município de Botucatu, confeccionado a partir dos dados do período de 1971-1995 (Figura 2), podemos observar um déficit hídrico médio de $2.9 \mathrm{~mm}$ para o mês de agosto, sendo a precipitação anual de 1530,3 $\mathrm{mm}$.

Com o objetivo de se avaliar se o ano de 1996 se apresentou-se de forma típica ou não foram confeccionados dois gráficos: o primeiro com os dados de precipitação e temperatura média e o segundo representando o balanço hídrico. Estes gráficos foram montados a partir dos dados de clima obtidos junto a estação meteorológica do Departamento de Ciências Ambientais da UNESP/Botucatu.

De acordo com o Figura 3, podemos observar uma estação quente e chuvosa de setembro à março e uma estação mais seca e fria de abril à agosto. Julho foi o mês mais seco e frio com $0,7 \mathrm{~mm}$ de precipitação total e $16^{\circ} \mathrm{C}$ de temperatura média. $\mathrm{O}$ mês mais chuvoso foi março com $270.6 \mathrm{~mm}$ e o mês mais quente foi janeiro com $23.5^{\circ} \mathrm{C}$. O mês de março com alta precipitação caracteriza um período de transição da estação 
chuvosa para a seca. A diminuição da precipitação nos meses de setembro, outubro e novembro caracteriza o período de transição da estação seca para a chuvosa.

Ao analisar os Balanços Hídricos para o período de 1971-1995 (Figura 2) e para o ano de 1996 (Figura 4), observamos o mesmo padrão para as estações secas e chuvosas, com exceção do mês de março que apresentou um alto valor de precipitação e dos meses de setembro, outubro e novembro que apresentaram valores decrescentes de precipitação no ano de 1996. O déficit hídrico acumulado foi relativamente alto neste ano. Estes dados porém não devem ser comparados, uma vez que no primeiro caso são apresentados dados médios de um período de 24 anos.

\subsubsection{Solos}

Segundo Carvalho et al. (1991), a Fazenda apresenta diversos tipos de solo, variando de latossolo roxo de origem basáltica no topo da "cuesta" e na encosta, até solos hidromórficos ricos em sedimentos férteis na várzea. $\mathrm{Na}$ "Mata da Bica", de acordo com os autores acima citados, há uma combinação de solos podzólicos e litólicos.

Com o objetivo de se avaliar o tipo de solo existente no centro do fragmento, onde se procedeu a análise estrutural e o levantamento fenológico, foi realizada a análise química e física de solo. Observações realizadas no campo em relação ao tipo de relevo, vegetação e a existência de afloramentos rochosos auxiliaram no enquadramento da área nos tipos de solos apresentados no levantamento efetuado pelos autores acima citados.

As amostras foram retiradas nas profundidades de $0-5 \mathrm{~cm}, 10-25 \mathrm{~cm}$ e $25-$ $60 \mathrm{~cm}$ em sete pontos alocados sistematicamente na área (Figura 5).

Foram feitas amostras compostas (5 pontos) para a profundidade de $0-5 \mathrm{~cm}$. As amostras foram analisadas pelo Laboratório de Fertilidade do Solo da UNESP/Botucatu conforme metodologia adotada pelo Instituto Agronômico de Campinas (Raij, 1983). 


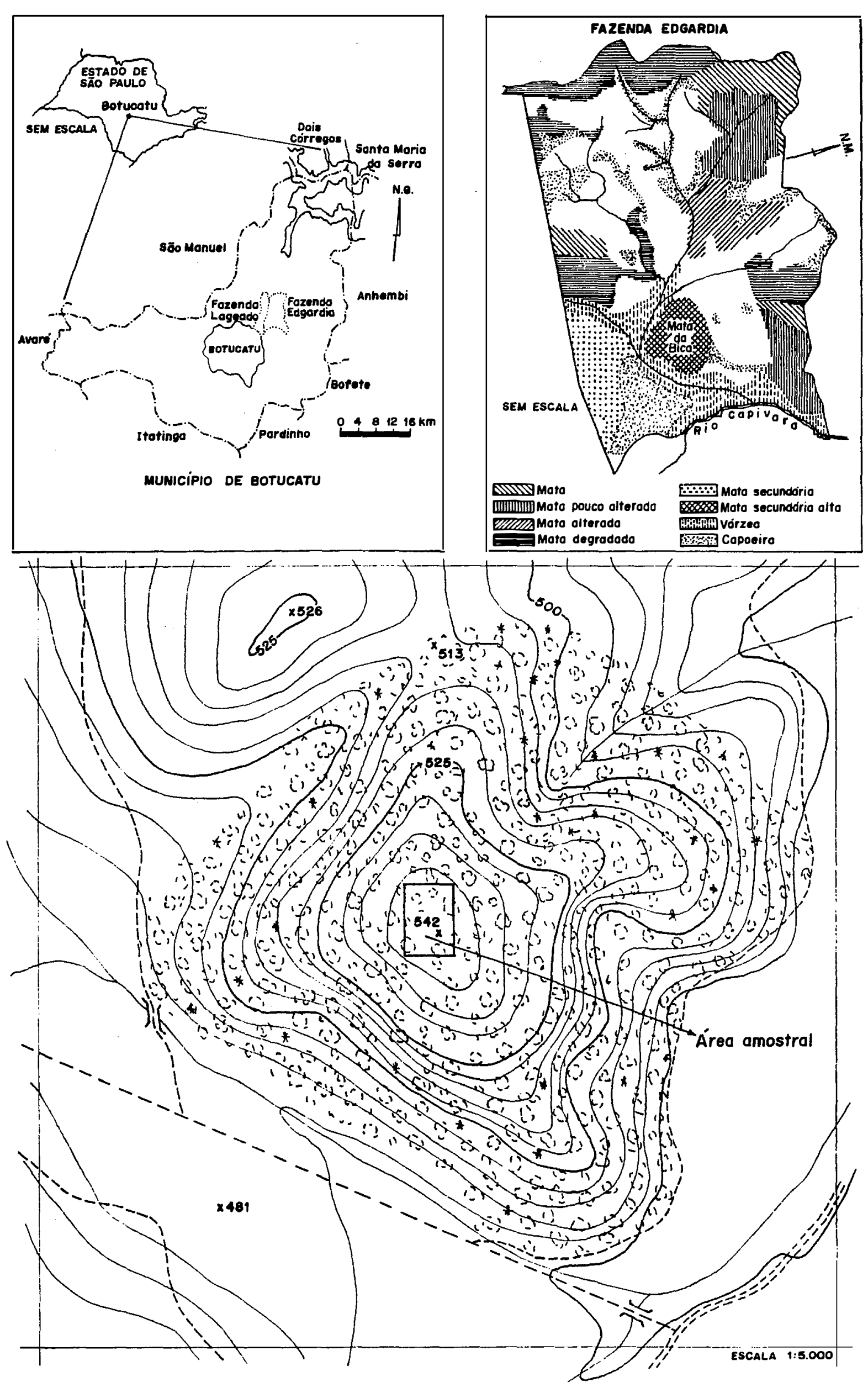

Figura 1 - Localizaçāo da área estudada (Mato da Bica) com sua caracterizaçāo topográfica. Fonte : (CARVALHO et ol., 1991) 


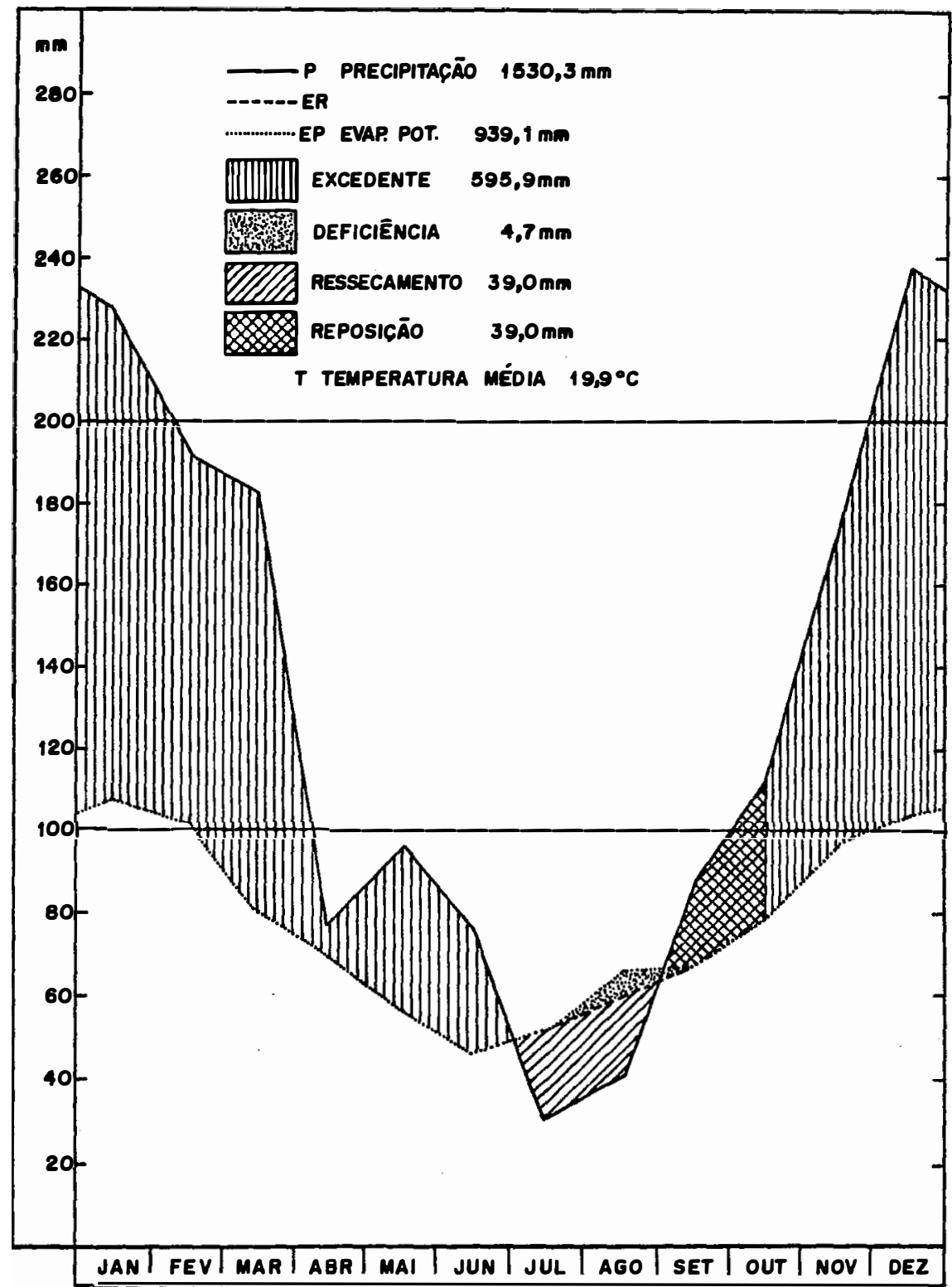

Figura 2 - Bolanço Hídrico do Município de Botucotu (THORNTHWAITE \& MATHER, 1955). 


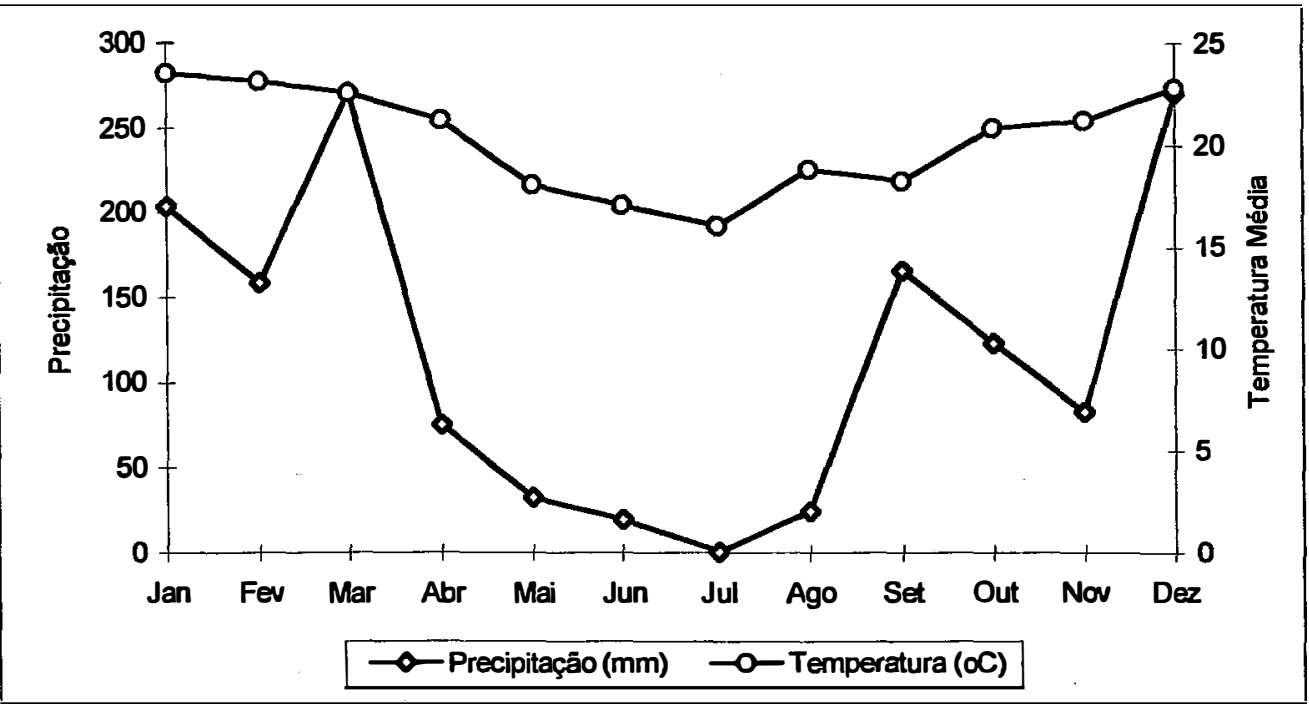

Figura 3 - Temperatura Média e Precipitação mensais do Município de Botucatu para o ano de 1996. Dados fornecidos pela estação meteorológica do Departamento de Ciências Ambientais da UNESP/Camous de Botucatu.

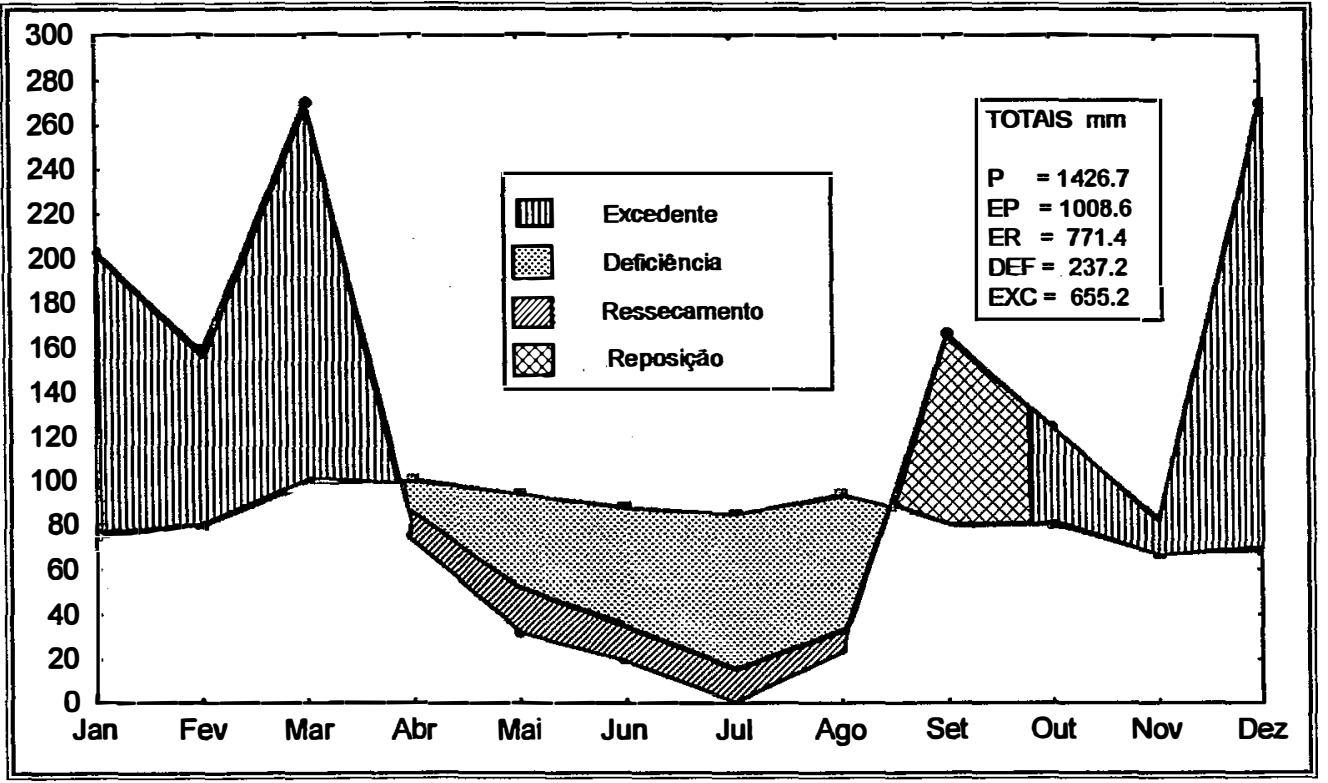

Figura 4 - Balanço Hídrico do Município de Botucatu para o ano de 1996, de acordo com Thomtwaite \& Mather (1955). Dados fornecidos pela estação meteorológica do Departamento de Ciências Ambientais da UNESPICampus de Botucatu. 


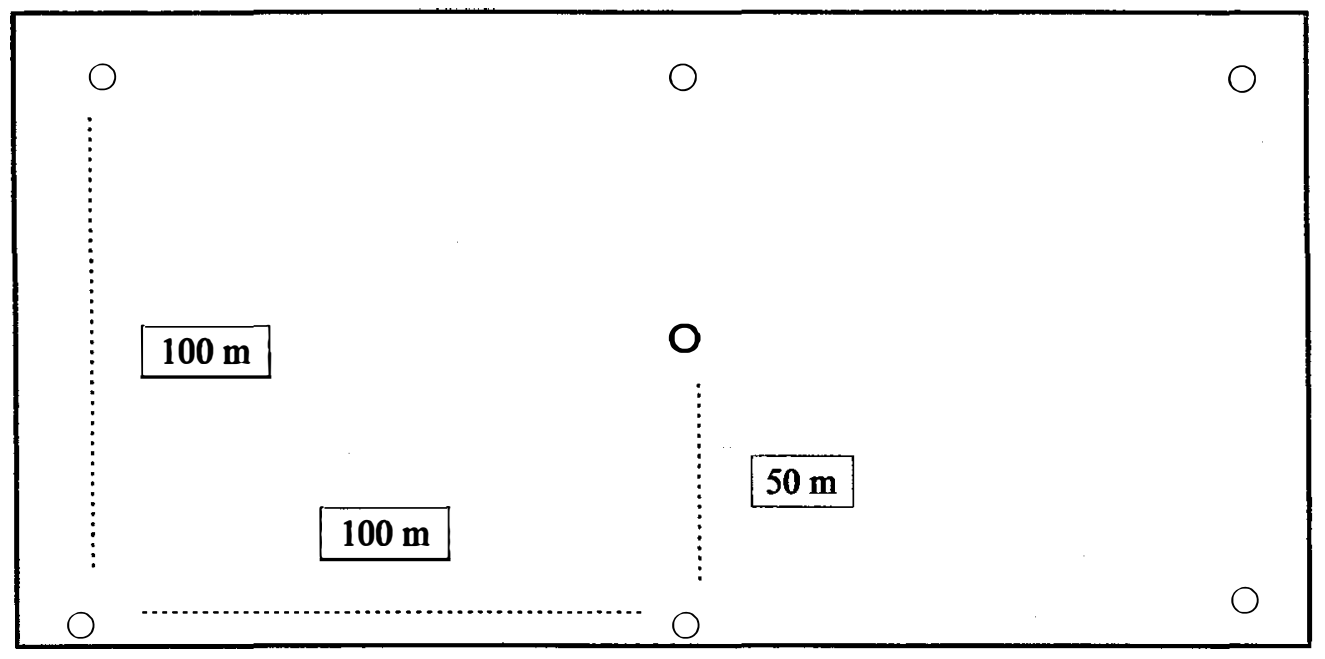

Figura 5. Esquema de coleta das amostras de solo dentro de uma área de dois hectares no interior da Mata da Bica, Botucatu-SP.

Os resultados das análises química e física das amostras de solo são apresentados no Anexo 1. Trata-se de um solo de boa fertilidade com teores altos de cálcio, magnésio, potássio e matéria orgânica. Os teores de argila conferem ao solo uma boa capacidade de retenção de água.

Estes resultados somados às observações de campo nos permite enquadrar 0 tipo de solo da área de estudo, ou seja, do centro do fragmento, no tipo Podzólico vermelho escuro, eutrófico, A moderado, textura média/argilosa, fase floresta tropical subperenifolia, relevo suave/ondulado, encontrado por Carvalho et al. (1991) na "Mata da Bica".

Os valores mais elevados de soma de bases (SB) foram observados na camada superficial $(0-5 \mathrm{~cm})$. $\mathrm{O}$ mesmo comportamento foi encontrado para o $\mathrm{pH}$, capacidade de troca catiônica (CTC), matéria orgância e saturação em bases (V\%). Este fato confirma a tendência observada por Silva \& Leitão Filho (1982) da apresentação de maior concentração dos nutrientes na camada superficial do solo de remanescentes florestais, onde a ciclagem de nutrientes é rápida e superficial.

Comportamento semelhante foi encontrados por Rodrigues et al. (submetido) para a Reserva de Santa Genebra, porém com valores mais baixos. Em relação à saturação em bases (V\%), os valores encontrados nas amostras da Mata da Bica variaram 
de 43 à $93 \%$, enquanto na Santa Genebra este valor não ultrapassou a 33\%, mesmo nas camadas mais superficiais. Este fato evidencia a maior fertilidade dos solos da Mata da Bica quando comparados com os solos da Santa Genebra.

\subsection{Análise estrutural}

Foram alocadas 200 parcelas de $10 \mathrm{~m} \times 10 \mathrm{~m}$ formando um gride de $200 \mathrm{~m} \times$ $100 \mathrm{~m}$ no centro do fragmento, onde procedeu-se a análise estrutural.

Para separar a área de estudo em unidades que representassem as diferentes fases de desenvolvimento propostas por Whitmore (1976, 1990), foi realizada uma análise de agrupamento baseada nas características estruturais de cada parcela.

As espécies foram classificadas em grupos ecológicos com o objetivo de comparar os resultados deste estudo com aqueles normalmente apresentados em estudos floríticos onde se pretende avaliar o estágio sucessional de determinada área.

\subsubsection{Fitossociologia}

Para o estudo fitossociológico em florestas tropicais recomenda-se a utilização de no mínimo 1 hectare. Desta forma, foram sorteadas 100 parcelas de $10 \mathrm{~m} \mathrm{X}$ $10 \mathrm{~m}$ para caracterização fitossociológica (Figura 6).

A suficiência amostral da área em questão foi analisada pela curva do coletor (Ramos Neto, 1993).

Nas parcelas foram amostrados todos os indivíduos com CAP (circunferência à altura do peito) $\geq 15 \mathrm{~cm}$, exceto para os indivíduos que perfilharam acima do solo $\mathrm{e}$ abaixo da altura do peito $(1,30 \mathrm{~m})$. Para estes foi adotado o seguinte critério: $\mathrm{o}$ indivíduo foi incluído quando pelo menos uma das ramificações obedecia ao critério de inclusão ( $\geq 15 \mathrm{~cm}$ de CAP), sendo então o CAP das demais ramificações anotado para a utilização nos cálculos de área basal. Não foram amostrados indivíduos mortos. 


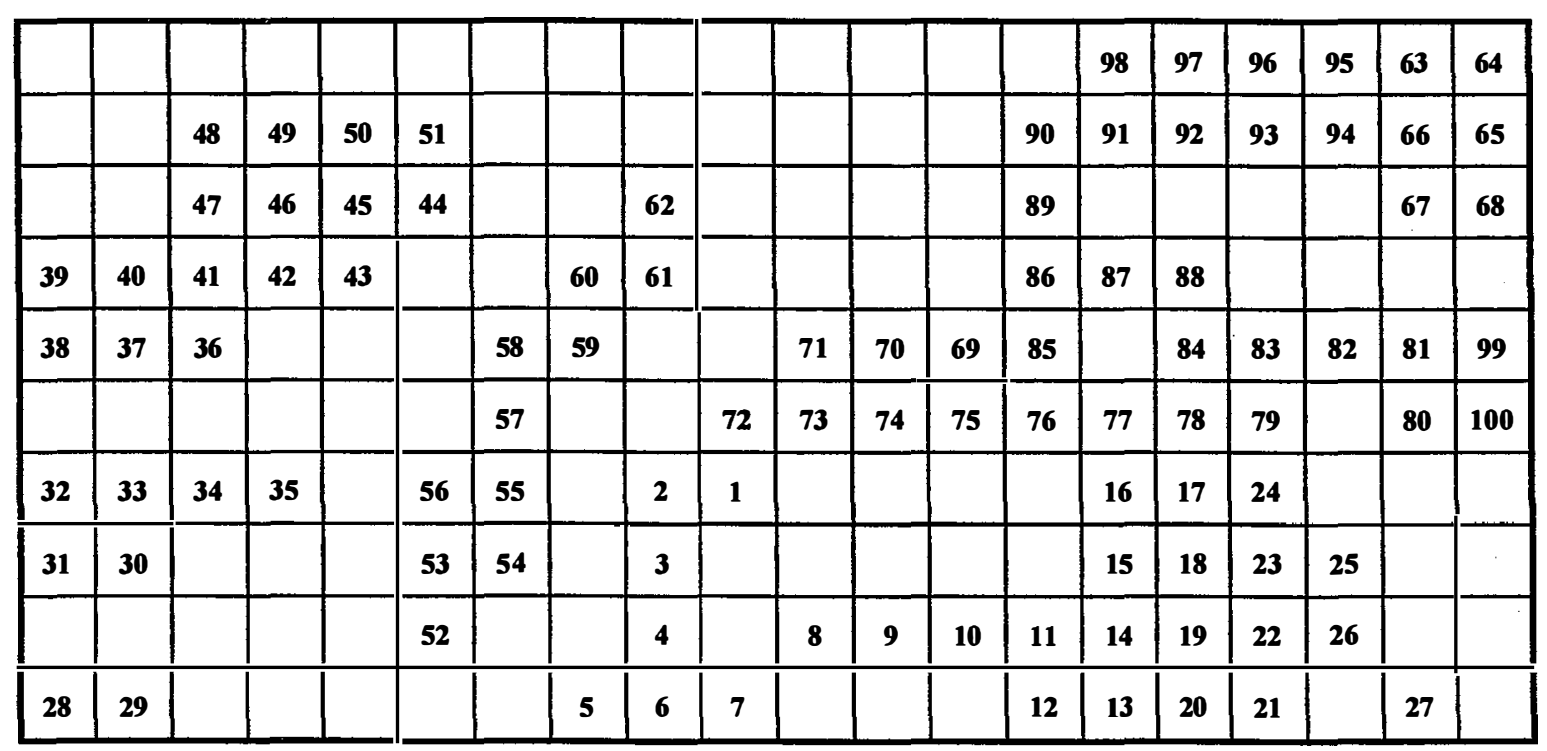

Figura 6 - Esquema do gride com as parcelas sorteadas para a realização do levantamento fitossociológico no interior da Mata da Bica, Botucatu-SP.

Os indivíduos amostrados foram numerados, identificados e mediu-se o perímetro do tronco na altura do peito. $\mathrm{O}$ material botânico foi processado e identificado no Departamento de Botânica da ESALQ/USP. Materiais reprodutivos foram identificados e incorporados no Herbário ESA da mesma Universidade.

A listagem florística segue as linhas gerais do sistema de Cronquist (1988).

Os dados foram analisados utilizando-se o programa FITOPAC (Shepherd, 1995). Os parâmetros considerados foram os normalmente utilizados em levantamentos fitossociológicos (Rodrigues, 1988).

\subsubsection{Mosaico florestal}

Além dos parâmetros normalmente utilizados em levantamentos fitossociológicos, outros parâmetros como Densidade de Cobertura, Altura do Dossel e Grau de Cobertura por Lianas foram estimados para cada parcela, com o objetivo de caracterizar ainda melhor as diferenças estruturais existentes entre as parcelas. Cabe ressaltar que na dificuldade de se encontrar uma metodologia bem definida para este tipo de estudo os parâmetros utilizados foram selecionados a partir da experiência de campo 
dos pesquisadores, da discussão com outros pesquisadores e de trabalhos que utilizaram individualmente estes parâmetros para as mais diversas finalidades.

\subsubsection{Densidade de Cobertura}

Para a estimativa deste parâmetro foi utilizado um densiômetro esférico de copa, que reflete uma amostra do dossel num espelho côncavo quadriculado. Através da contagem dos quadrados interceptados pela folhagem, estima-se a porcentagem de cobertura.

Em cada parcela foram alocados sistematicamente 13 pontos (em forma de $\mathrm{x}$ passando pelo centro da parcela). Em cada ponto foram feitas 4 leituras (N, S, L e O) extraindo-se uma média para cada ponto. Destas médias obteve-se uma única média para cada parcela.

\subsubsection{Altura do Dossel}

Em cada parcela foram estimadas as alturas de 5 indivíduos que fariam parte do dossel. Destas alturas extraiu-se uma média da altura do dossel para cada parcela.

\subsubsection{Grau de Cobertura por Lianas}

Para cada indivíduo amostrado foi atribuído uma nota para cobertura por lianas sendo:

$$
\begin{aligned}
& 0=\text { ausência de lianas } \\
& 1=1-25 \% \text { da copa coberta } \\
& 2=26-50 \% \text { da copa coberta } \\
& 3=51-75 \% \text { da copa coberta } \\
& 4=76-100 \% \text { da copa coberta }
\end{aligned}
$$

Foram somadas as notas de todos os indivíduos da parcela gerando um nota total para cada parcela. 


\subsubsection{Análise de agrupamento}

A partir das variáveis geradas pelo FITOPAC para cada parcela como: Número de Indivíduos, Número de Espécies, Área Basal, Dominância Média e Diâmetro Médio, mais as variáveis levantadas em campo como: Densidade de Cobertura, Altura do Dossel e Grau de Cobertura por Lianas, procedeu-se a Análise de Agrupamento.

O tipo de análise utilizada foi "K-means Clustering", através do programa STATISTICA FOR WINDOWS, versão 4.3 de 1993. Trata-se de uma técnica de agrupamento não hierárquica desenvolvida para agrupar itens dentro de um conjunto de $\mathrm{K}$ clusters (grupos). $\mathrm{O}$ objetivo desta análise é minimizar a variabilidade dentro de cada cluster e maximizar a variabilidade entre clusters. Realizado o agrupamento, a interpretação dos resultados se dá através da média para cada cluster em cada variável que permite avaliar quão diferentes são os clusters. A escolha de um determinado $\mathrm{K}$ (número de clusters) depende do conhecimento do assunto.

Neste trabalho, foi adotado inicialmente um $\mathrm{K}$ igual a três correspondendo as fases de desenvolvimento do mosaico florestal propostas por Whitmore $(1978,1990)$, ou seja, fases de clareira, fase de construção e fases madura.

Além dos resultados obtidos com a análise de agrupamento, alguns parâmetros fitossociológicos são apresentados para a área total e para cada grupo de parcelas com o objetivo de caracterizar ainda melhor a estrutura de cada grupo e verificar a eficiência desta análise.

\subsubsection{Classificação das espécies em grupos ecológicos}

As espécies foram classificação em grupos ecológicos baseando-se nos trabalhos realizados por Gandolfi et al. (1995), que separou as espécies em 4 categorias sucessionais:

a) pioneiras - dependentes de luz que não ocorrem no sub-bosque, se desenvolvendo em clareiras ou nas bordas da floresta;

b) secundárias iniciais - ocorrem em condições de sombreamento médio ou luminosidade não muito intensa, ocorrendo em clareiras pequenas, bordas de clareiras grandes, bordas da floresta ou sub-bosque não densamente sombreado; 
c) secundárias tardias - se desenvolvem no sub-bosque em condições de sombra leve ou densa, podendo aí permanecer toda a vida ou então crescer até alcançar o dossel ou a condição de emergente;

d) sem caracterização - em função da carência de informações não puderam ser enquadradas em nenhuma das categorias anteriores.

Espécies não citadas neste trabalho foram classificadas com base em outros trabalhos e em observações do comportamento e hábito destas na área de estudo, observando a densidade e a dominância destas nos grupos de parcelas em diferentes fases de desenvolvimento do mosaico florestal (Rodrigues et al., 1992; Ivanauskas et al., 1994; Bernacci \& Leitão Filho, 1996; Rozza, 1996; Rodrigues et al., submetido).

\subsection{Fenologia}

A escolha das espécies e do número de indivíduos arbóreos e arbustivos, para a composição da amostra a ser observada fenologicamente, foi feita da seguinte maneira:

a) todas as espécies de árvores e arbustos que foram amostradas no levantamento fitossociológico;

b) para as espécies que apresentaram o número de indivíduos inferior a 10 , foram incluídos todos os indivíduos;

c) para espécies que apresentaram mais de 10 indivíduos, foram sorteados apenas 10 indivíduos do total amostrado para a comunidade.

A utilização de 10 indivíduos para representar a população foi feita com base no trabalho realizado por Fournier \& Charpantier (1975), que afirma ser suficiente para estudos fenológicos uma amostra de 10 indivíduos por espécie, quando estes são selecionados a medida em que aparecem na mata, ou uma amostra de 5 indivíduos, quando são escolhidos ao acaso ou em forma sistemática.

No caso de lianas devido à dificuldade de se isolar os indivíduos, identificar as espécies e determinar a cobertura expressa pela dominância, decidiu-se por fazer as observações em parcelas, onde anotou-se as espécies que estavam florescendo e ou frutificando em cada parcela.

As observações foram realizadas com o auxilio de um binóculo e através da coleta de material botânico. Foram confeccionadas excicatas do material botânico fértil, que serviram para identificação botânica e registro de cada fenofase. 
A caracterização das fenofases foi realizada conforme metodologia proposta por Morellato (1991). Foi considerado como período de floração aquele em que o indivíduo estava com suas flores abertas e como período de frutificação aquele em que os frutos se apresentavam maduros e prontos para serem dispersos. Foi considerado como brotamento o período que se iniciava com o aparecimento de pequenas folhas brilhantes, com cor verde clara, amarelada ou vermelha. Quando as folhas atingiam $3 / 4$ de tamanho de uma folha adulta, foi considerado como final do período de brotamento. A queda de folhas foi considerada quando 1) suas folhas mudaram de cor, adquirindo um tom verde mais escuro, alaranjado ou avermelhado, 2) se enrolaram, 3) quando caíram com facilidade ao ventar, 4) quando sob o indivíduo houve muitas folhas caídas, 5) quando foram notadas falhas na copa ou galhos sem folha. Foi também observada a perda de turgescência das folhas, caracterizando também a fenofase de perda das folhas.

Foram definidas as épocas de floração, frutificação, queda de folhas e brotamento para árvores e arbustos, e floração e frutificação para lianas. Foi realizada uma comparação entre as formas de vida para a área toda e para cada fase de desenvolvimento do mosaico florestal.

As espécies arbóreas e arbustivas foram ainda classificadas de acordo com o posicionamento no mosaico florestal (clareira e borda de clareira) e no perfil estrutural (dossel, sub-bosque e sub-dossel) com o intuito de comparar a fenologia em relação as fases de desenvolvimento do mosaico florestal com aquela realizada com base na classificação sucessional das espécies. A classificação das espécies foi realizada com base nos trabalhos anteriormente citados.

$\mathrm{Na}$ maior parte dos estudos fenológicos de comunidades, os padrões fenológicos são apresentados na forma de gráficos do número de espécies ou porcentagem de espécies por fenofase em determinado período de tempo. No presente trabalho foi utilizado como indicador, além da porcentagem espécie por fenofase, a porcentagem de indivíduos, no caso de espécies arborescentes, e a porcentagem de parcelas com a presença de lianas por fenofase.

Os cálculos para se chegar ao número de indivíduos da comunidade em determinada fenofase, para as espécies de árvores e arbustos com mais de 10 indivíduos, foram efetuados extrapolando-se a proporção de indivíduos que apresentavam o evento dentro da amostra para o conjunto de indivíduos de cada espécie encontrado no levantamento fitossociológico. 


\section{RESULTADOS}

\subsection{Análise estrutural}

Neste item serão apresentados os resultados obtidos no levantamento fitossociológico e os outros parâmetros utilizados na caracterização do mosaico florestal como Densidade de Cobertura, Altura do Dossel e Grau de Cobertura por Lianas.

\subsubsection{Fitossociologia}

\subsubsection{Composição florística}

No levantamento fitossociológico foram amostrados 1.104 indivíduos pertencentes a 31 familias, 50 gêneros e 61 espécies, conforme Tabela 1. Das 61 espécies, 2 estão indicadas apenas em gênero e 1 em familia. A não identificação de todos os indivíduos em espécie ocorreu basicamente com as espécies da familia Myrtaceae, que não foi possível coletar material reprodutivo para identificação. 
Tabela 1 - Lista de espécies arbóreas e arbustivas encontradas na Mata da Bica, em Botucatu-SP, ordenadas por familias com respectivos nomes vulgares, grupos ecológicos (G.E.) e posicionamento (P): mosaico florestal (horizontal) e perfil estrutural (vertical).

\begin{tabular}{|c|c|c|c|c|}
\hline 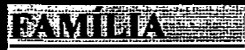 & 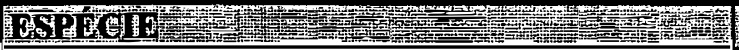 & WOND DUIGA & Bint & Pis \\
\hline Anacardiaceae & Astronium graveolens Jacq. & Guaritá & St & $\overline{\mathrm{BC}}$ \\
\hline Anonaceae & Rollinia sylvatica [St.Hil.]Mart. & Araticum & $\mathrm{Si}$ & $\mathrm{SD}$ \\
\hline \multirow[t]{2}{*}{ Apocynaceae } & Aspidosperma polyneuron Muell.Arg. & Peroba-rosa & St & D \\
\hline & Aspidosperma ramiflorum Muell.Arg. & Guatambu & |St & $\bar{D}$ \\
\hline \multirow[t]{2}{*}{ Arecaceae } & Syagrus oleraceae [Mart]Becc. & Guariroba & ISi & II \\
\hline & Syagrus romanzoffiana [Cham.]Glassman. & Gerivá & $\mathbf{S i}$ & $\bar{I}$ \\
\hline Asteraceae & Vernonia diffusa Less. & Cambará-açu & $\mathbf{P}$ & $\mathbf{C}$ \\
\hline Bombacaceae & Chorisia speciosa St.Hil. & Paineira & $\mathbf{S i}$ & $\mathrm{D}$ \\
\hline \multirow[t]{3}{*}{ Boraginaceae } & Cordia ecalyculata Vell. & Café-de-bugre & $\overline{\mathrm{Si}}$ & $\mathrm{BC}$ \\
\hline & Cordia trichotoma [Vell.]Arrab. ex Steud. & Louro-pardo & $\mathbf{I S i}$ & $\mathrm{D}$ \\
\hline & Patagonula americana $\mathrm{L}$. & Guajuvira & $\mathrm{Si}$ & D \\
\hline Cactaceae & Cereus hildmannianus K.Schum. & Mandacaru & Sc & $I$ \\
\hline \multirow[t]{3}{*}{ Caesalpiniaceae } & Bauhinia forficata Link. & Unha-de-vaca & $\overline{\mathrm{Si}}$ & $\mathrm{C}$ \\
\hline & Holocalyx balansae Mich. & Alecrim-de-campinas & St & $\mathrm{D}$ \\
\hline & Peltophorum dubium [Spr.]Taub. & Canafistula & $\mathbf{S i}$ & $\mathrm{BC}$ \\
\hline \multirow[t]{2}{*}{ Caricaceae } & Carica quercifolia [St.Hil.]Hieron. & Mamãozinho & $\mathbf{P}$ & $\mathrm{C}$ \\
\hline & Jacaratia spinosa [Aubl.]DC. & Jaracatiá & $\mathbf{P}$ & $\mathrm{C}$ \\
\hline Celastraceae & Maytenus aquifolia Mart. & Espinheira Santa & St & SB \\
\hline Euphorbiaceae & Securinega guaraiuva M.Kuhlm. & Guaraiuva & St & $\mathrm{D}$ \\
\hline \multirow[t]{7}{*}{ Fabaceae } & Centrolobium tomentosum Guill. ex Benth. & Araribá & $\mathbf{S i}$ & $\mathrm{BC}$ \\
\hline & Machaerium brasiliense Vog. & Jacarandá & $\overline{\mathrm{St}}$ & $\mathrm{D}$ \\
\hline & Machaerium scleroxylum Tul. & |Caviúna-paulista & St & D \\
\hline & |Machaerium stipitatum [DC.]Vog. & Sapuva & |Si & D \\
\hline & Myroxylon peruiferum L.f. & Cabreúva & St & D \\
\hline & Lonchocarpus muehlbergianus Hassl. & Embira-de-sapo & $\mathbf{S i}$ & $\mathrm{BC}$ \\
\hline & Sweetia fruticosa Spreng. & Sucupira-amarela & St & $\overline{\mathrm{SD}}$ \\
\hline \multirow[t]{2}{*}{ Flacourtiaceae } & Casearia gossypiosperma Briquet. & Pau-espeto & St & D \\
\hline & Casearia sylvestris Sw. & Guaçatonga & P & $\mathbf{C}$ \\
\hline Lecythidaceae & |Cariniana estrellensis [Raddi.]O.Kuntze. & Jequitibá-branco & St & $\mathrm{D}$ \\
\hline Lacistemaceae & Lacistema hasslerianum Chodat. & Pau-de-lagarto & $\mathrm{St}$ & $\mathrm{SB}$ \\
\hline Malvaceae & Bastardiopsis densiflora Hassl. & Jangada-branca & $\mathrm{P}$ & $\mathrm{C}$ \\
\hline \multirow[t]{4}{*}{ Meliaceae } & Trichilia casarettii C. DC. & Catiguá & TSt & SB \\
\hline & |Trichilia catigua A.Juss. & Catiguá & |St & ISD \\
\hline & Trichilia clausseni C. DC. & Catiguá-vermelho & St & SD \\
\hline & Trichilia elegans A. Juss. & Catiguá-de-folha-miúda & St & SB \\
\hline \multirow[t]{2}{*}{ Mimosaceae } & Acacia polyphylla DC. & |Monjoleiro & |Si & BC \\
\hline & Parapiptadenia rigida [Benth.]Brenan. & Angico-vermelho & Si & $\mathrm{D}$ \\
\hline Moraceae & Maclura tinctoria [L.]D.Don. & Taiúva & $\mathrm{Si}$ & $\overline{\mathrm{BC}}$ \\
\hline \multirow[t]{4}{*}{ Myrtaceae } & |Campomanesia guaviroba [DC.|Kiaersk. & Guabiroba & St & ISD \\
\hline & Campomanesia guazumifolia [Camb.]Berg. & Sete-capotes & St & SD \\
\hline & Eugenia uniflora Berg. & Pitanga & $\mathrm{St}$ & $\mathrm{SB}$ \\
\hline & Myrcia sp & & $\mathrm{St}$ & SB \\
\hline
\end{tabular}




\begin{tabular}{|c|c|c|c|c|}
\hline 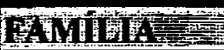 & 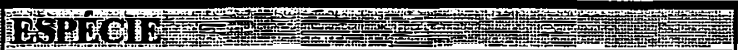 & 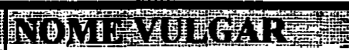 & 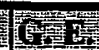 & IIIsis \\
\hline & Myrcianthes pungens [Berg.]Legr. & Guabiroba-açu & $\mathrm{St}$ & SB \\
\hline & Myrciaria sp & & St & SB \\
\hline & Myrtaceae II & & Sc & SB \\
\hline Nyctaginaceae & Guapira opposita [Vell.]Reitz. & Maria-mole & $\mathbf{S i}$ & SB \\
\hline Phytolacaceae & Gallesia integrifolia [Spr.]Harms. & Pau-d'alho & TSt & D \\
\hline Rhamanaceae & Rhamnidium elaeocarpum Reiss. & Saguaraji-amarelo & $\mathrm{Si}$ & $\mathrm{BC}$ \\
\hline Rubiaceae & Coussarea hydrangiaefolia Benth. \& Hook. & & $\mathrm{St}$ & SB \\
\hline & Coutarea hexandra [Jacq.] Shumann. & & Si & SD \\
\hline Rutaceae & Balfourodendron riedelianum [Engl.]Engl. & Pau-marfim & St & $\mathrm{D}$ \\
\hline & Esenbeckia febrifuga [St.Hil.]A.Juss. & Mamoninha & $\overline{\mathrm{Si}}$ & SB \\
\hline & Esenbeckia grandiflora Mart. & Guaxupita & St & SB \\
\hline & Metrodorea nigra St.Hil. & Carrapateira & Si & SB \\
\hline & Zanthoxylum hyemale St.Hil. & Mamica-de-porca & $P$ & $\mathrm{BC}$ \\
\hline Sapindaceae & Allophylus edulis [St. Hil.]Radlk. & Fruta-de-faraó & $\overline{\mathbf{P}}$ & TC \\
\hline & Diatenopteryx sorbifolia Radlk. & Maria-preta & $\mathbf{S i}$ & D \\
\hline & \begin{tabular}{|lll}
$\begin{array}{l}\text { Chrysophyllum } \\
\text { Eichl.]Engl. }\end{array}$ & gonocarpum & [Mart.
\end{tabular} & Guatambu-de-leite & St & BC \\
\hline Ulmaceae & Celtis af iguaneae [Jacq.]Sargent. & Grão-de-galo & $\mathbf{P}$ & C \\
\hline Urticaceae & Urera baccifera [L.]Gaud. & Urtigão & $\mathbf{P}$ & $\bar{C}$ \\
\hline Verbenaceae & Aloysia virgata [Ruiz \& Pav.]A.Juss. & Lixeira & $\mathbf{P}$ & C \\
\hline
\end{tabular}

Legenda:

$$
\begin{aligned}
& \mathrm{P}=\text { pioneira } \\
& \mathrm{Si}=\text { secundária inicial } \\
& \mathrm{St}=\text { secundária tardia } \\
& \mathrm{Sc}=\text { sem classificação }
\end{aligned}
$$

\author{
$\mathrm{C}=$ clareira \\ $\mathrm{BC}=$ borda de clareira
}

$\mathrm{D}=$ dossel

$\mathrm{SD}=$ sub-dossel

$\mathrm{SB}=$ sub-bosque

$I=$ indiferentes

\subsubsection{Parâmetros gerais}

De acordo com a curva do coletor, a área amostrada foi suficiente para representação da comunidade em questão (Figura 7).

De acordo com a Figura 8, pode-se observar que as 3 familias mais numerosas foram Meliaceae (44,57\%), Apocynaceae (19,57\%) e Fabaceae (7,70\%) somando $71,84 \%$ do total de indivíduos amostrados (1.104 indivíduos). Se considerarmos as familias Caesalpiniaceae, Fabaceae e Mimosaceae de Cronquist (1981) como a familia Leguminosae de Engler (Joly, 1977), esta se apresentaria com 14,13 \% do total de indivíduos.

$\mathrm{O}$ destaque da família Meliaceae se deu principalmente devido ao número elevado de indivíduos das espécies Trichilia claussenii e Trichilia catigua, com 303 e 152 indivíduos respectivamente. No caso da familia Apocynaceae, foi Aspidosperma 


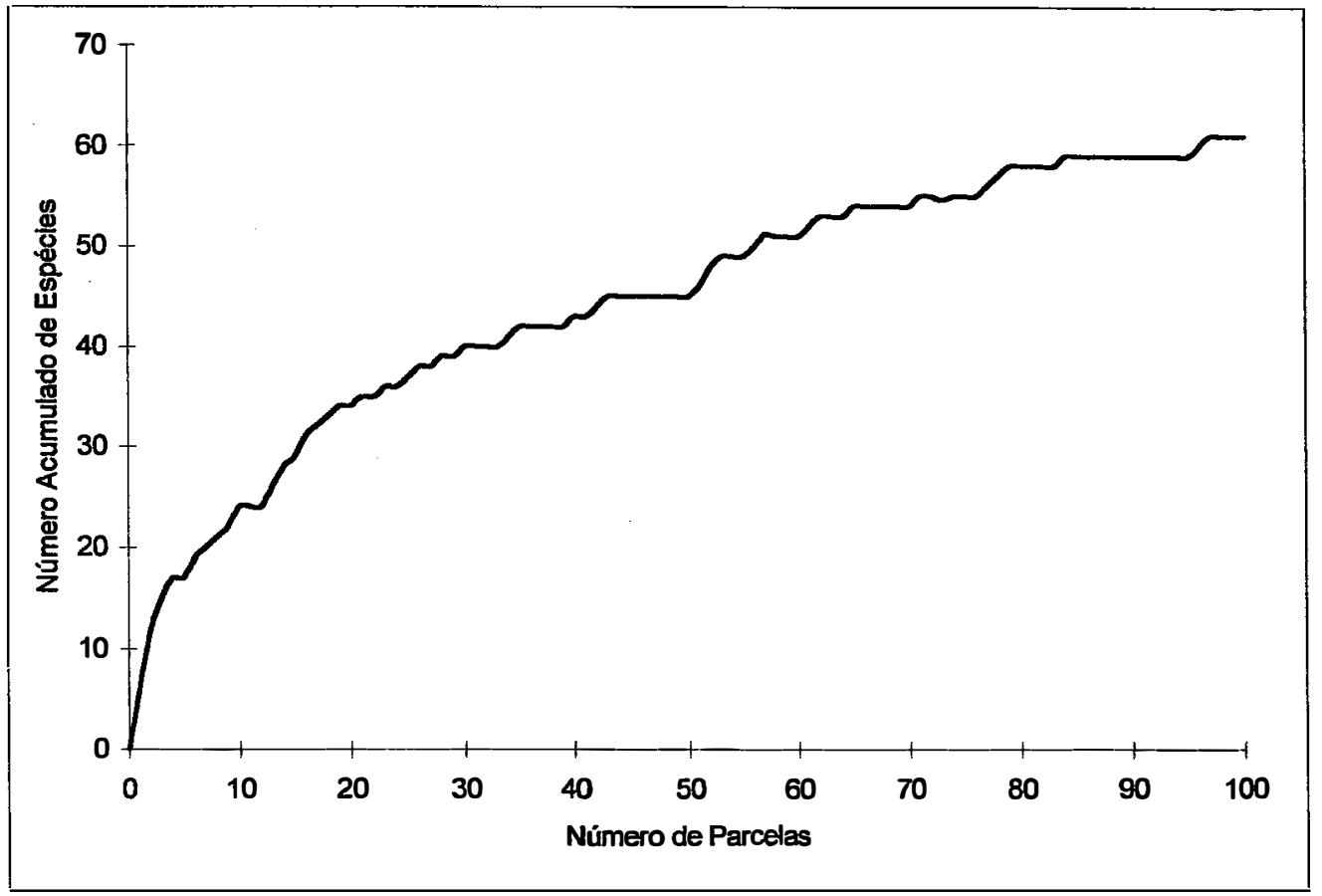

Figura 7 - Curva do coletor ou suficiência amostral para o levantamento fitossociológico realizado em uma área de $100 \mathrm{~m} \times 200 \mathrm{~m}$ no interior da Mata da Bica, Botucatu - SP. 


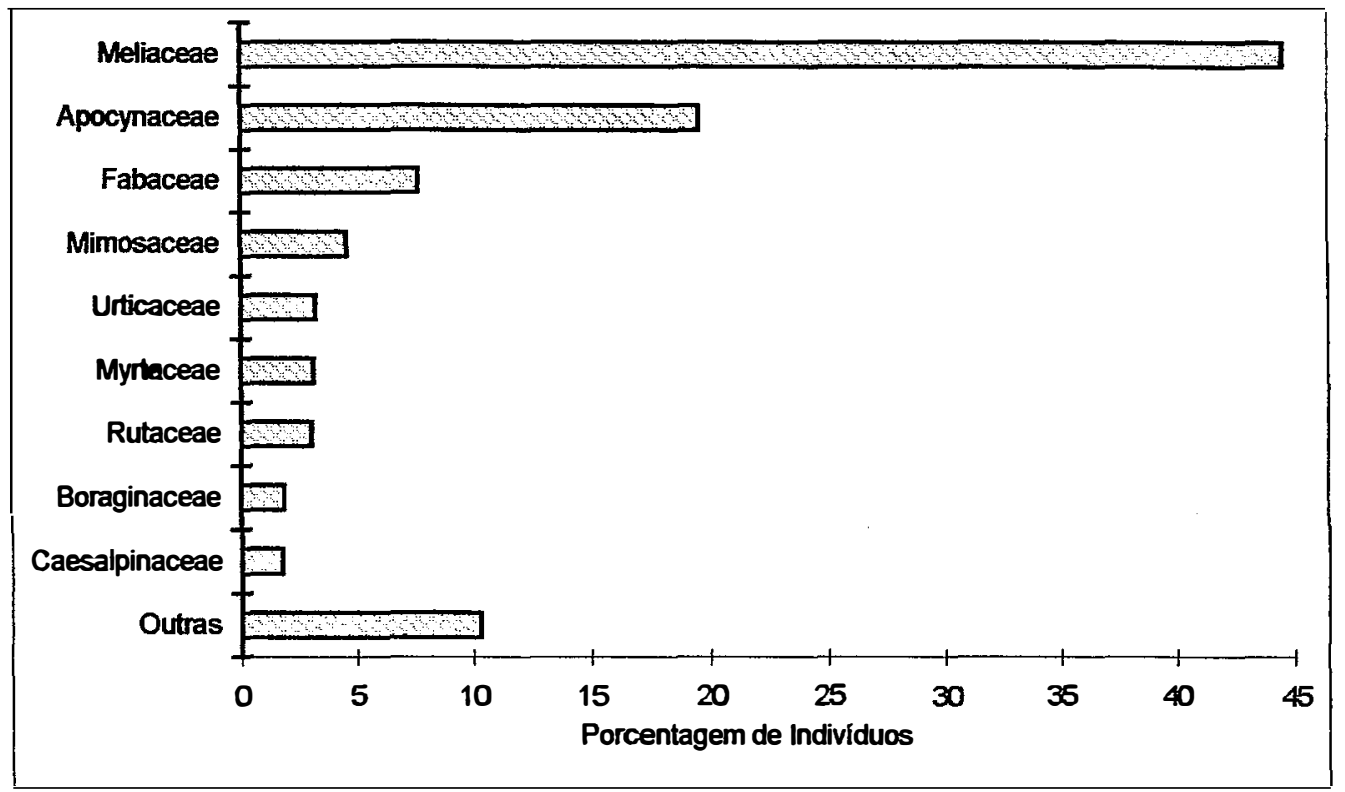

Figura 8 - Porcentagem de Indivíduos por família encontrado no levantamento fitossociológico realizado no interior da Mata da Bica, Botucatu-SP.

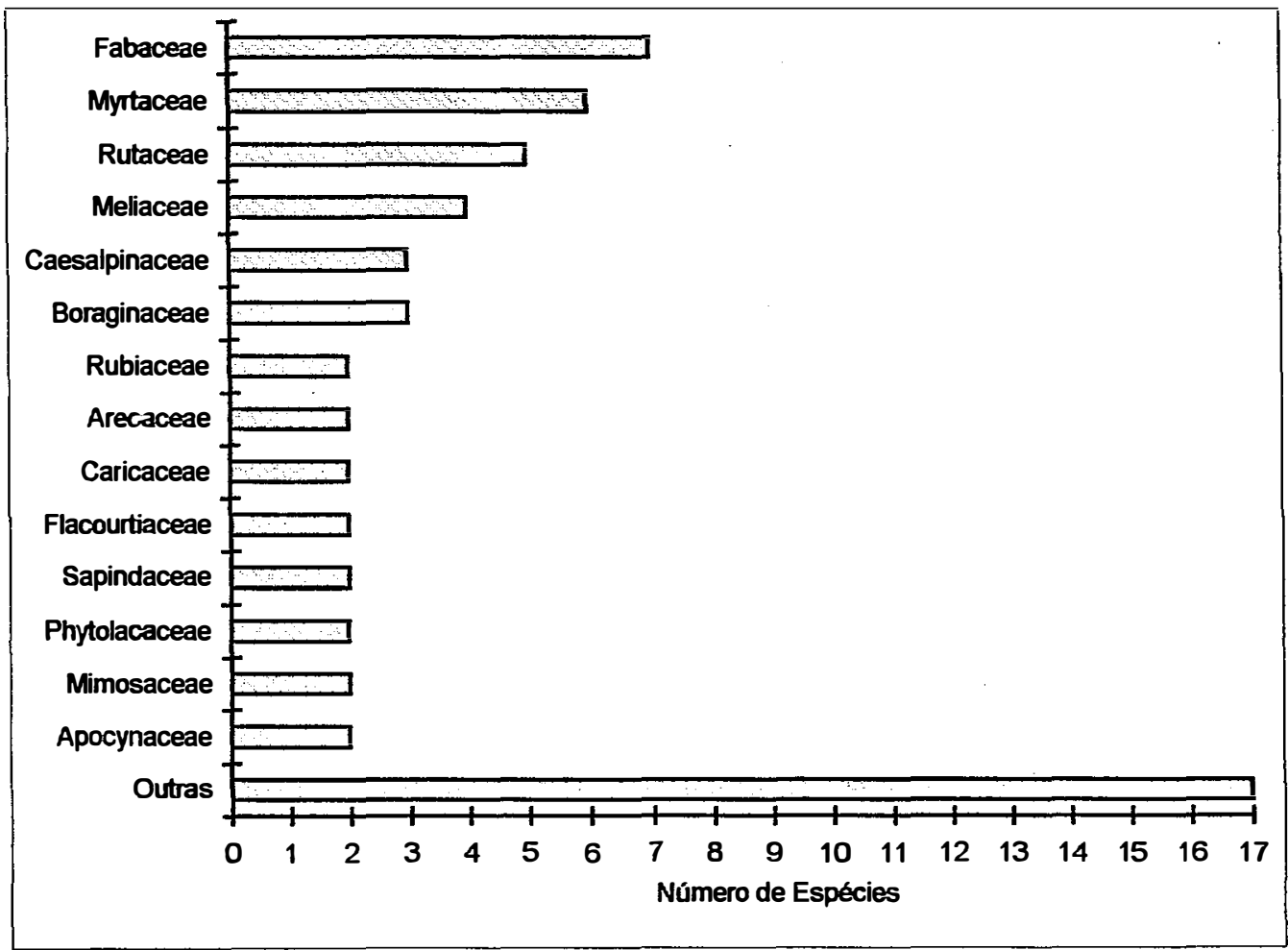

Figura 9 - Número de Espécies por família encontrado no levantamento fitossociológico realizado no interior da Mata da Bica, Botucatu-SP. 
polyneuron a espécie responsável por este destaque, com 209 indivíduos. Dos 85 indivíduos apresentados pela familia Fabaceae, 40 foram de apenas uma de suas 7 espécies (Machaerium stiptatum) (Anexo 2).

A Figura 9 nos mostra que a familia de maior riqueza foi a Fabaceae com 7 espécies, seguida da Myrtaceae e Rutaceae, com 6 e 5 espécies respectivamente. Se considerarmos a familia Leguminosae, esta se apresentaria como a espécie de maior riqueza (12 espécies).

De acordo com a Figura 10, as espécies mais numerosas foram Trichilia claussenii, Aspidosperma polyneuron e Trichilia catigua, somando $60,15 \%$ do número total de indivíduos.

Das 61 espécies amostradas neste levantamento, 32 apresentaram menos de 5 indivíduos. As espécies com menor densidade foram Cordia trichotoma (Si), Bastardiopsis densiflora (P), Maclura tinctoria (Si), Rollinia sylvatica (Si), Coutarea hexandara (Si), Casearia sylvestris (P), Vernonia diffusa (P) e Coussarea hydrangiaefolia (St) com apenas 1 indivíduo (Anexo 3).

As dez espécies com maior valor de importância estão representadas na Figura 11, com seu respectivos valores de Densidade Relativa, Dominância Relativa e Freqüência Relativa.

Aspidosperma polyneuron apresentou o maior IVI $(52,21)$ em decorrência de valores elevados tanto de densidade quanto de freqüência e dominância relativas. $O$ mesmo ocorreu para Trichilia claussenii $(51,85)$ e Trichilia catigua $(30,24)$, porém estas apresentaram proporcionalmente menor dominância e maior densidade relativa, justamente pelo fato de serem espécies típicas de subdossel.

Parapiptadenia rígida, Machaerium stiptatum, Patagonula americana, Gallesia integrifolia e Chorisia speciosa se destacaram devido aos elevados valores de dominância relativa apresentados por suas populações, com a presença de indivíduos com áreas basais significativas.

$\mathrm{O}$ índice de diversidade de Shannon $\left(\mathrm{H}^{\prime}\right)$ encontrado foi de 2,72. Para o Índice de Equabilidade o valor encontrado foi de 0.66 . 


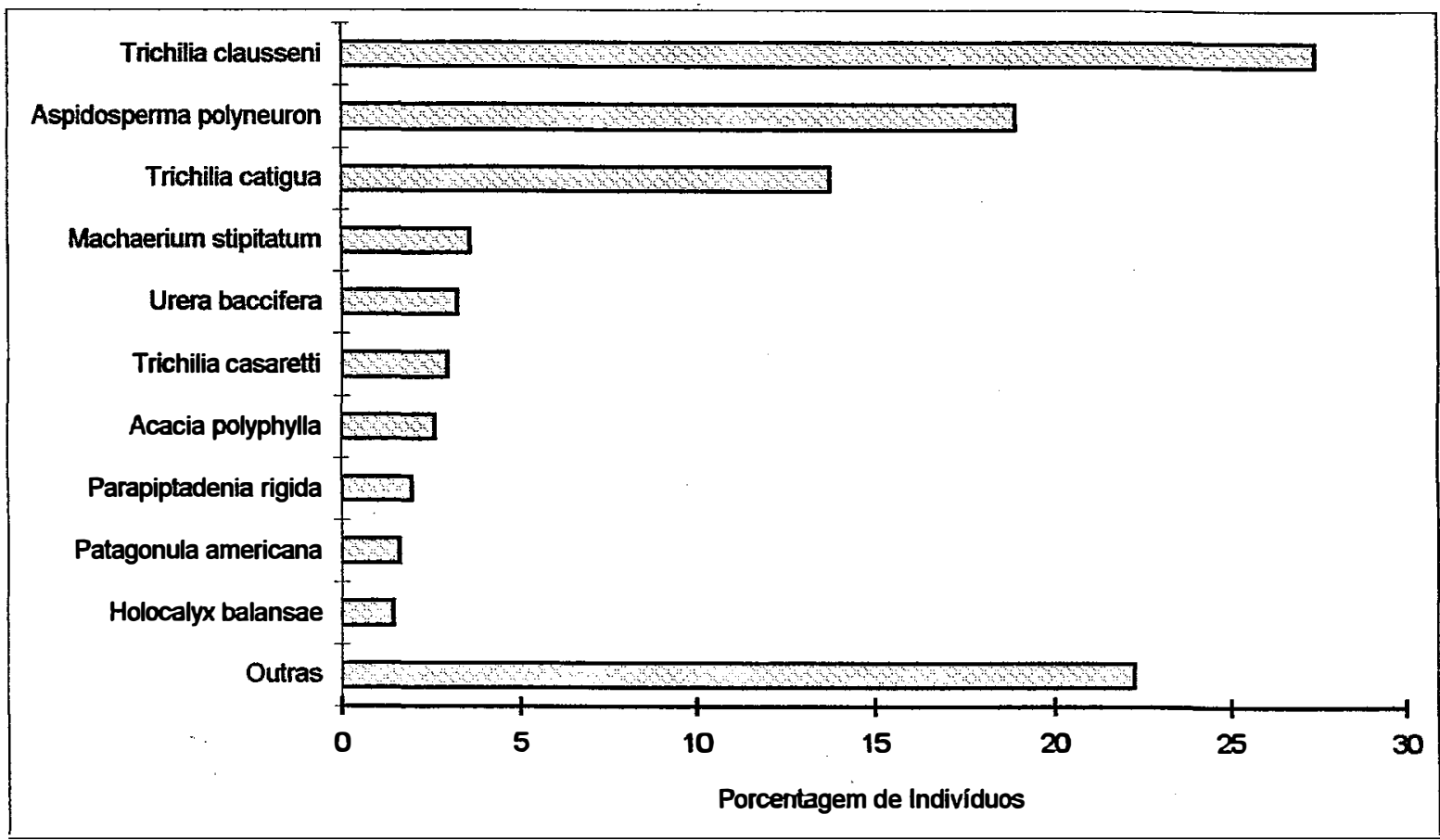

Figura 10 - Porcentagem de Individuos por espécies encontrado no levantamento fitossociológico realizado no interior da Mata da Bica, Botucatu-SP.

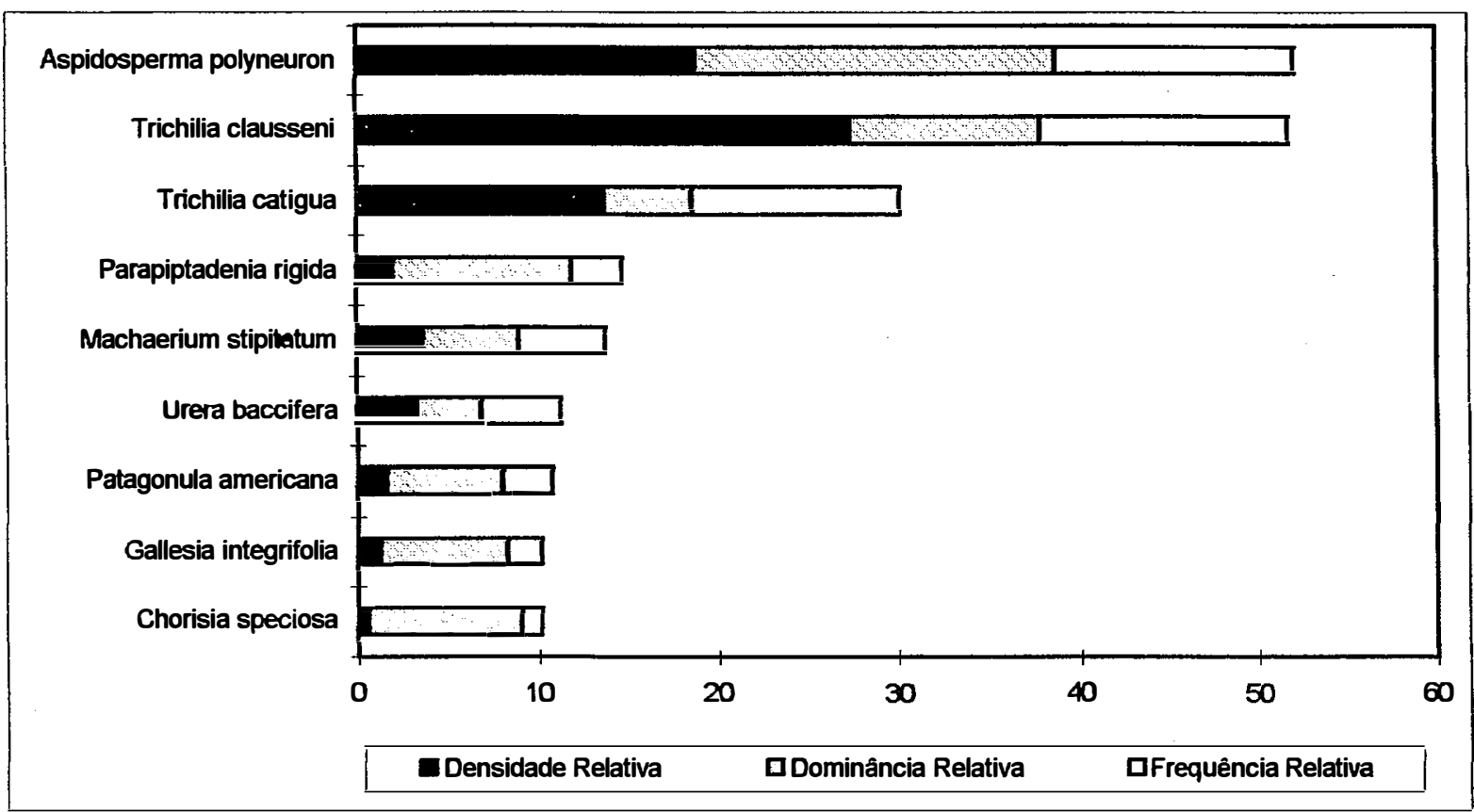

Figura 11 - Valor de Importância (IVI) para as espécies encontrado no levantamento fitossociológico realizado no interior da Mata da Bica, Botucatu-SP. 


\subsubsection{Estágio sucessional}

Das 61 espécies arbóreas e arbustivas encontradas, 10 (16,4\%) foram classificadas como pioneiras, 21 (34,4\%) como secundárias iniciais, 28 (45,9\%) como secundárias tardias e $2(3,3 \%)$ sem classificação (Tabela 1). Esta mesma proporção foi observada para o número de indivíduos e para o valor de importância (Figuras 12 e 13).

Em relação à estrutura, das espécies que apresentaram maior IVI (Figura 11) 4 foram classificadas como secundárias tardias, 5 como secundárias iniciais e 1 como pioneira.

\subsubsection{Mosaico florestal}

Os parâmetros fitossociológico para as parcelas obtidos no levantamento, bem como os dados para Grau de Cobertura por Lianas, Altura do Dossel e Porcentagem de Cobertura são apresentados no Anexo 4.

\subsubsection{Análise de agrupamento}

Ao processar a análise de agrupamento com o número de três clusters já definidos, observou-se que algumas parcelas que apresentavam indivíduos de grande porte com copa bastante danificada e tronco atacado por pragas foram enquadradas na fases madura. $\mathrm{O}$ que se esperava era diferenciar estas parcelas através da Porcentagem de Cobertura do Dossel visivelmente redurida, mas a variação encontrada para esta variável foi muito pequena devido principalmente à grande cobertura formada por lianas nestas parcelas. Desta forma, processou-se um nova análise de agrupamento desta vez com $\mathrm{k}$ igual a 4, caracterizando uma quarta fases de degradação.

O gráfico de valores médios para os grupos de parcelas (Figura 14) mostra que a Porcentagem de Cobertura foi muito próxima para os quatro grupos. Em relação à Altura do Dossel os grupos 1 e 3 apresentaram valores mais elevados e os grupos 2 e 4 mais baixos. Para o Grau de Cobertura por Lianas os grupos 1 e 3 foram muito próximos, sendo que o grupo 4 apresentou valor mais elevado. Para o Diâmetro Médio os grupos 2 e 4 apresentaram valores semelhantes, sendo o valor mais elevado apresentado pelo 


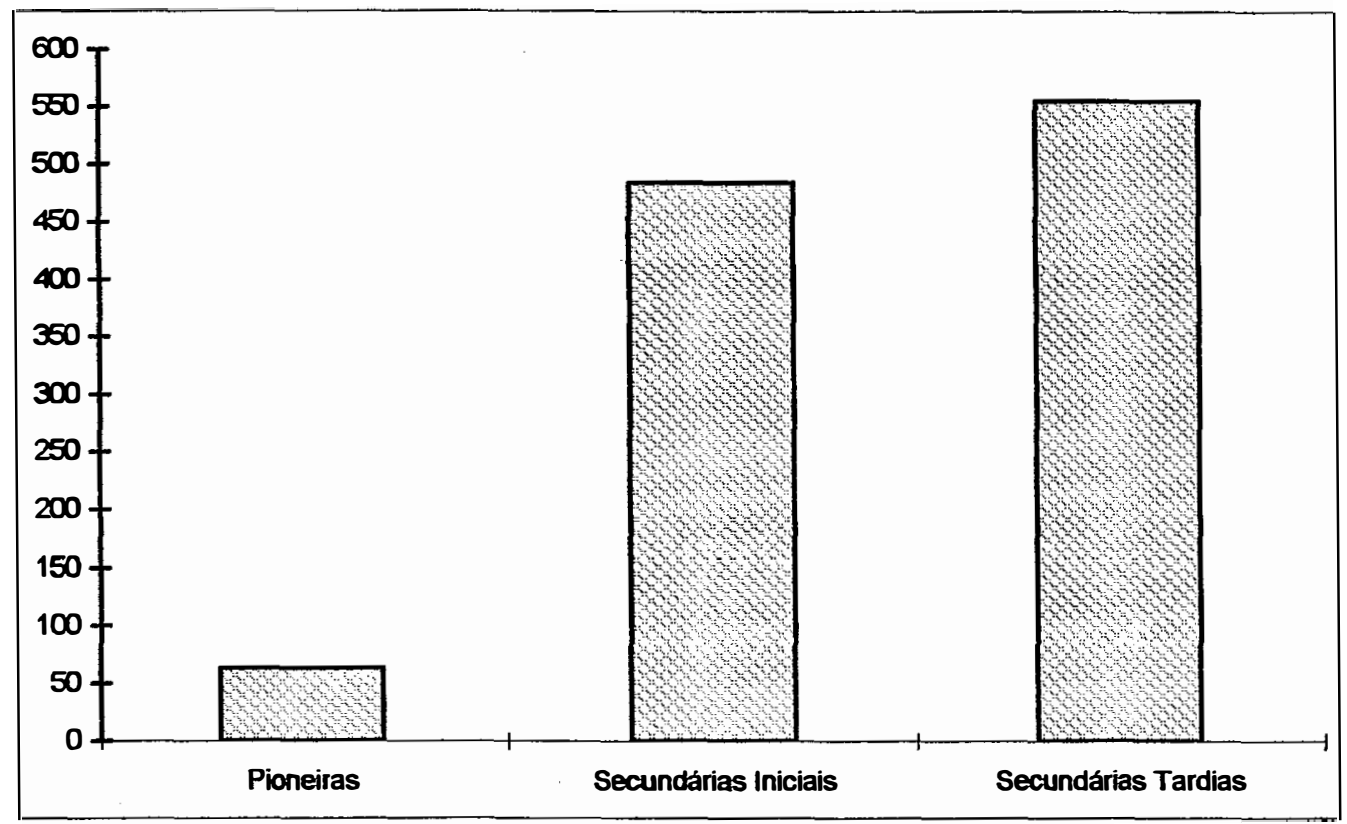

Figura 12 - Número de Individuos por Grupo Ecológico encontrado no levantamento fitossociológico realizado no interior da Mata da Bica, Botucatu-SP.

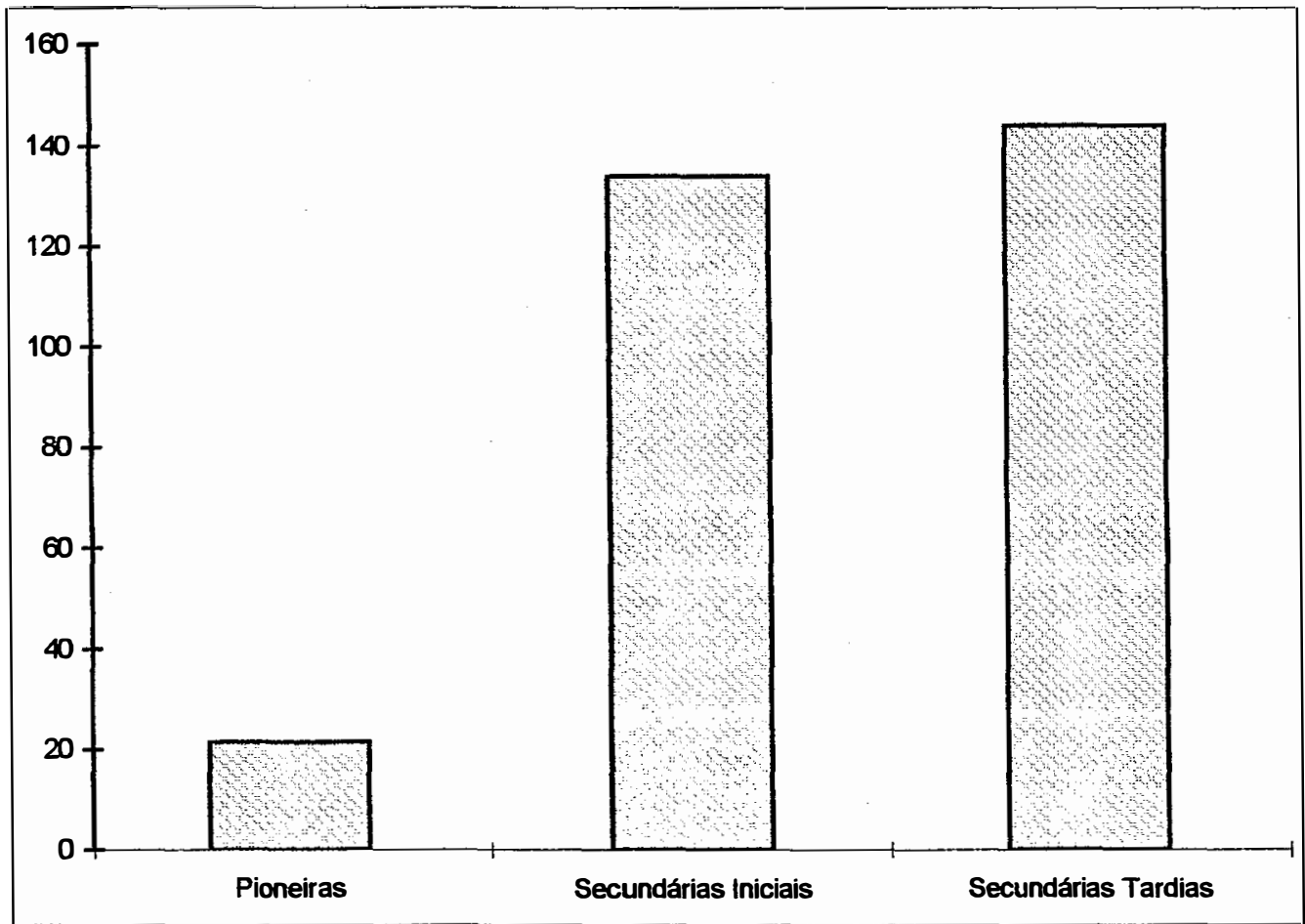

Figura 13 - Valor de Importância (IVI) por Grupo Ecológico encontrado no levantamento fitossociológico realizado no interior da Mata da Bica, Botucatu-SP. 


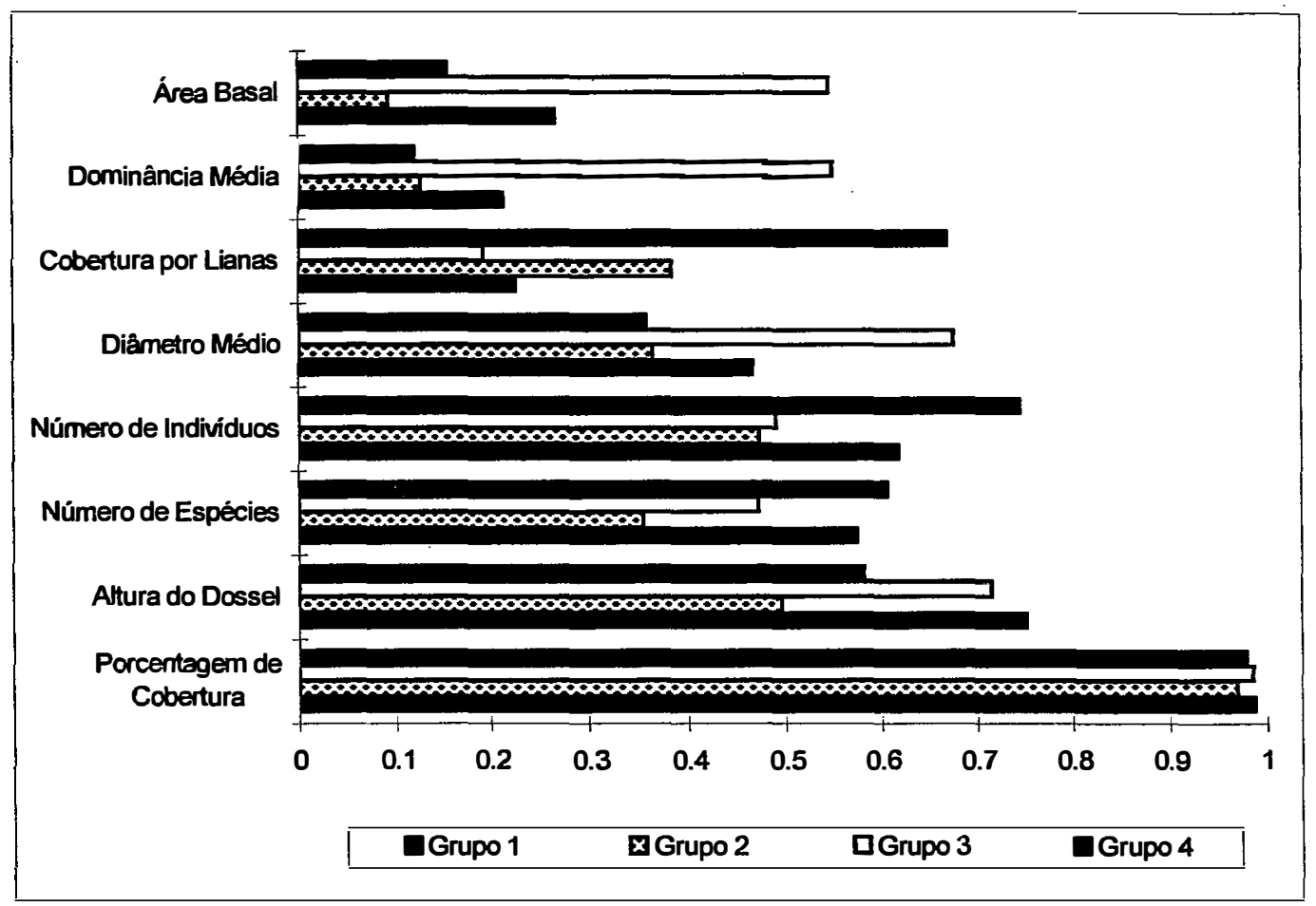

Figura 14 - Médias de Área Basal, Dominância Média, Cobertura de Lianas, Diâmetro Médio, Número de Indivíduos, Número de Espécies, Altura do Dossel e Porcentagem de Cobertura para cada grupo de parcelas da Mata da Bica, Botucatu-SP. Os valores apresentados representam a proporção que cada valor tem do valor máximo encontrado para cada variável, que neste caso foi considerado igual a 1 (um). 
grupo 3. Valor intermediário foi apresentado pelo grupo 1. O mesmo comportamento foi apresentado para Dominância Média e Área Basal. Para a variável Número de Indivíduos, o grupo 4 apresentou valor mais elevado. Valores mais baixos e mais próximos foram apresentados pelos grupos 2 e 3 . 0 grupo 1 apresentou valor intermediário. Já para a variável Número de Espécies, os grupos 1 e 4 apresentaram valores mais altos e próximos, sendo o valor mais baixo apresentado pelo grupo 2.0 grupo 3, neste caso, apresentou valor intermediário.

Estes dados nos mostram uma tendência para dois comportamentos diferenciados :

1) grupos 1 e 3 - apresentam valores mais elevados para Área Basal, Dominância Média, Diâmetro Médio e Altura do Dossel e mais baixos para Grau de Cobertura por Lianas;

2) grupos 2 e 4 - apresentam valores mais elevados para Grau de Cobertura por Lianas e mais baixos para Área Basal, Dominância Média, Diâmetro Médio e Altura do Dossel.

Cabe ressaltar que, no caso do grupo 4, o elevado Grau de Cobertura por Lianas pode estar relacionado ao grande número de indivíduos, uma vez que esta variável foi levantada individualmente. $\mathrm{O}$ mesmo pode estar ocorrendo para número de espécies.

Desta forma, seguindo a classificação proposta por Whitmore $(1978,1990)$ teremos quatro situações bem definidas:

1) 31 parcelas dominadas por áreas em fase de clareira - grupo 2;

2) 24 parcelas dominadas por áreas em fase de construção - grupo 4;

3) 33 parcelas dominadas por áreas em fase madura - grupo 1;

4) 12 parcelas dominadas por áreas em fase de degradação - grupo 3.

\subsubsection{Parâmetros fitossociológicos}

Através da análise fitossociológica realizada para a área toda e para cada fase de desenvolvimento do mosaico florestal pode-se observar que a fase madura apresenta a maior Área Basal Total. A menor Área Basal Total e a menor Densidade foram apresentadas pela fase de clareira, sendo a maior Densidade apresentada pela fase de construção (Tabela 2). A maior Densidade de Pioneiras foi encontrada na fase de clareira 
seguida da fases de degradação. Já para Densidade de Secundárias Tardias o maior valor foi apresentado pela fase madura seguida da fase de construção.

\begin{tabular}{|l|r|r|r|r|r|}
\hline \multicolumn{1}{|c|}{ Parâmetros } & $\begin{array}{c}\text { Área } \\
\text { Total }\end{array}$ & $\begin{array}{c}\text { Fase } \\
\text { Madura }\end{array}$ & $\begin{array}{r}\text { Fase de } \\
\text { Clareira }\end{array}$ & $\begin{array}{r}\text { Fase de } \\
\text { Degradação }\end{array}$ & $\begin{array}{c}\text { Fase de } \\
\text { Construção }\end{array}$ \\
\hline Número de Parcelas & 100 & 33 & 31 & 12 & 24 \\
\hline Densidade (N.Ind./ha) & 1.280 .5 & 1260.61 & 780.65 & 1033.33 & 1333.33 \\
\hline Área Basal Total (m²/ha) & 41.78 & 100.37 & 35.18 & 75.48 & 45.14 \\
\hline $\begin{array}{l}\text { Densidade de Pioneiras } \\
\text { (N.Ind./ha) }\end{array}$ & 61.00 & 27.27 & 106.45 & 66.67 & 45.83 \\
\hline $\begin{array}{l}\text { Densidade de Secundárias } \\
\text { Tardias (N.Ind./ha) }\end{array}$ & 315.00 & 421.21 & 216.13 & 316.67 & 337.5 \\
\hline
\end{tabular}

Tabela 2 - Parâmetros fitossociológicos para a área total e para cada fase de desenvolvimento do mosaico florestal na Mata da Bica, em Botucatu-SP.

A partir destes dados pode-se observar que existem duas situações bem definidas:

1) fases madura - apresenta os valores mais elevados para Área Basal Total, Densidade de Secundárias Tardias e o valor mais baixo para Densidade de Pioneiras;

2) fases de clareira- apresenta o valor mais elevado para Densidade de Pioneiras e os valores mais baixos para Área Basal Total, Densidade de Secundárias Tardias.

Cabe ressaltar que a fases de construção, além de ter apresentado a média mais elevada para Número de Indivíduos na análise de agrupamento, apresentou também o maior valor de Densidade na análise fitossociológica. No caso da fases de degradação, que apresentou a média mais alta para Área Basal na análise de agrupamento, ficou em segundo lugar na análise fitossociológica quando avaliada a Área Basal Total. Estes dados vêm reforçar os resultados obtidos na análise de agrupamento.

\subsection{Fenologia}

Os resultados serão apresentados primeiramente para a comunidade toda (1 ha) e depois para as comunidades correspondentes às fases de desenvolvimento do 
mosaico florestal. A comunidade correspondente à fase de degradação foi excluída desta análise comparativa por apresentar um número muito redurido de parcelas.

Foram observadas 61 espécies entre árvores e arbustos e 30 espécies de lianas. Destas espécies de lianas foram identificadas 13 famílias, 19 gêneros de 23 espécies diferentes. Outras 7 espécies não foram identificadas, devido principalmente a dificuldade de coleta de material botânico destas espécies que se encontravam em locais de difícil acesso no dossel da floresta e em baixa densidade (Tabela 3). Além disso, 7 espécies encontram-se identificadas apenas em gênero.

Tabela 3 - Lista de espécies de lianas observadas na Mata da Bica, em Botucatu-SP, ordenadas por familias, com os respectivos nomes vulgares atribuídos pela própria equipe de campo.

\begin{tabular}{|c|c|c|c|}
\hline NÚMBRO & 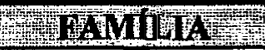 & 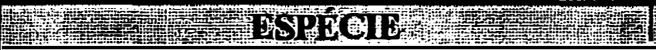 & NOMG WULERT \\
\hline 1 & Amaranthaceae & Pfaffia paniculata (Mart.) O. Kuntze & espiga branca 3 \\
\hline 2 & Bignoniaceae & Adenocalymna bracteatum (Cham.) DC. & big alaranjada \\
\hline 3 & Bignoniaceae & Adenocalymna marginatum (Cham.) DC & flor amarela \\
\hline 4 & Bignoniaceae & Arrabidaea triplinervia Baill. & $\begin{array}{l}\text { flores lilás com interior } \\
\text { creme }\end{array}$ \\
\hline 5 & Bignoniaceae & Clitostoma sp & $\begin{array}{l}\text { flor creme com interior } \\
\text { rosa }\end{array}$ \\
\hline$\overline{6}$ & Bignoniaceae & Lundia cf obliqua Sonder. & $\begin{array}{l}\text { flor branca com interior } \\
\text { violeta }\end{array}$ \\
\hline 7 & Bignoniaceae & Mansoa difficilis (Cham.) Bur.\& K. Schum & flores roxas \\
\hline 8 & Bignoniaceae & Mansoa sp & $\begin{array}{l}\text { flor roxa com interior } \\
\text { branco }\end{array}$ \\
\hline 9 & Bignoniaceae & Melloa quadrivalvis (Jaca.) A.H. Gentry & flor roxa dura \\
\hline 10 & Cactaceae & Pereskia aculeata Mill. & cipó espinho \\
\hline 11 & Convolvulaceae & Ipomoea sp 1 & $\begin{array}{l}\text { flor branca pequena ou } \\
\text { flor branca pequena col } \\
15\end{array}$ \\
\hline 12 & Convolvulaceae & Ipomoea sp 2 & flores brancas col 21 \\
\hline 13 & Cucrubitaceae & Wilbrandia aff verticulata (Vell.) Cogn & espiga amarela \\
\hline 14 & Dioscoreaceae & Dioscorea sp & espiga branca 2 col 30 \\
\hline 15 & Fabaceae & Centrosema sp & cipó vermelho \\
\hline 16 & Fabaceae & Rynchosia phaseoloides D.C. & $\begin{array}{l}\text { flor amarela pequena col } \\
27 \text { e } 31\end{array}$ \\
\hline 17 & Malphiguiaceae & Dicella holosericea (Juss.) Griseb. & cipó serra \\
\hline 18 & Phytolacaceae & Sequieria langsdorffii & liana alada \\
\hline 19 & Rhamnaceae & Gouania virgata Reissek. & espiga branca 1 col 9 \\
\hline 20 & Solanaceae & Solanum sp 1 & cipó maracujá \\
\hline 21 & Verbenaceae & Petrea volubilis L. & petrea sp \\
\hline 22 & Vitaceae & Cissus cf campestris (Baker) Camb. & cipó branco \\
\hline
\end{tabular}




\begin{tabular}{|c|c|c|c|}
\hline 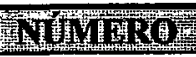 & Haf & 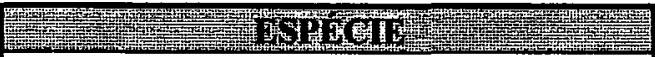 & 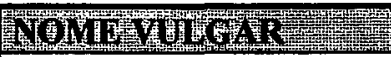 \\
\hline 23 & Vitaceae & Cissus cf sulcicaulis (Baker) Planch. & cipó bolas \\
\hline 24 & & & flor rosa pequena \\
\hline 25 & & & flor lilás pequena \\
\hline 26 & & & $\begin{array}{l}\text { flor rosa com interior } \\
\text { branco }\end{array}$ \\
\hline 27 & & & flor rosa grande \\
\hline 28 & & & cipó novo com frutos \\
\hline 29 & & & cipó carambola \\
\hline 30 & & & flor amarela pequena \\
\hline
\end{tabular}

\subsection{1. Área total}

\subsubsection{Floração}

Ao analisar as espécies arbóreas da comunidade, foi encontrado um pico de floração que vai do final de fevereiro ao início de abril atingindo 6,5\% das espécies da comunidade e um pico no final de novembro de mesma intensidade. Durante a estação seca (maio-agosto) cerca de $3 \%$ das espécies se mantiveram em floração (Figura 15). Esta manutenção da floração durante a estação seca se deu por parte das espécies de dossel.

Considerando a freqüência do evento na comunidade, expressa pela porcentagem de indivíduos arbóreos com flores no trecho estudado, foi observado um período de maior floração que vai do final de janeiro ao início de abril. Ocorreram dois picos de floração, um no final de janeiro com pouco mais de 3,0\% dos indivíduos em floração e outro menor isolado, no final de novembro com cerca de $1,5 \%$ dos indivíduos nesta fenofase. Durante toda a estação seca foi observada uma pequena porcentagem de indivíduos em floração que não chegou a atingir $0,5 \%$ do total de indivíduos da comunidade (Figura 15). O primeiro pico de floração se deu exclusivamente pelos indivíduos de clareira, enquanto que o segundo pico ocorreu por conta dos indivíduos de dossel.

Para as espécies arbustivas foram observados dois períodos de maior floração, o primeiro do final de março ao início de maio, atingindo menos de $2 \%$ das espécies da comunidade, e outro do final de outubro ao início de janeiro, chegando a atingir 5\% das espécies (Figura 16). 

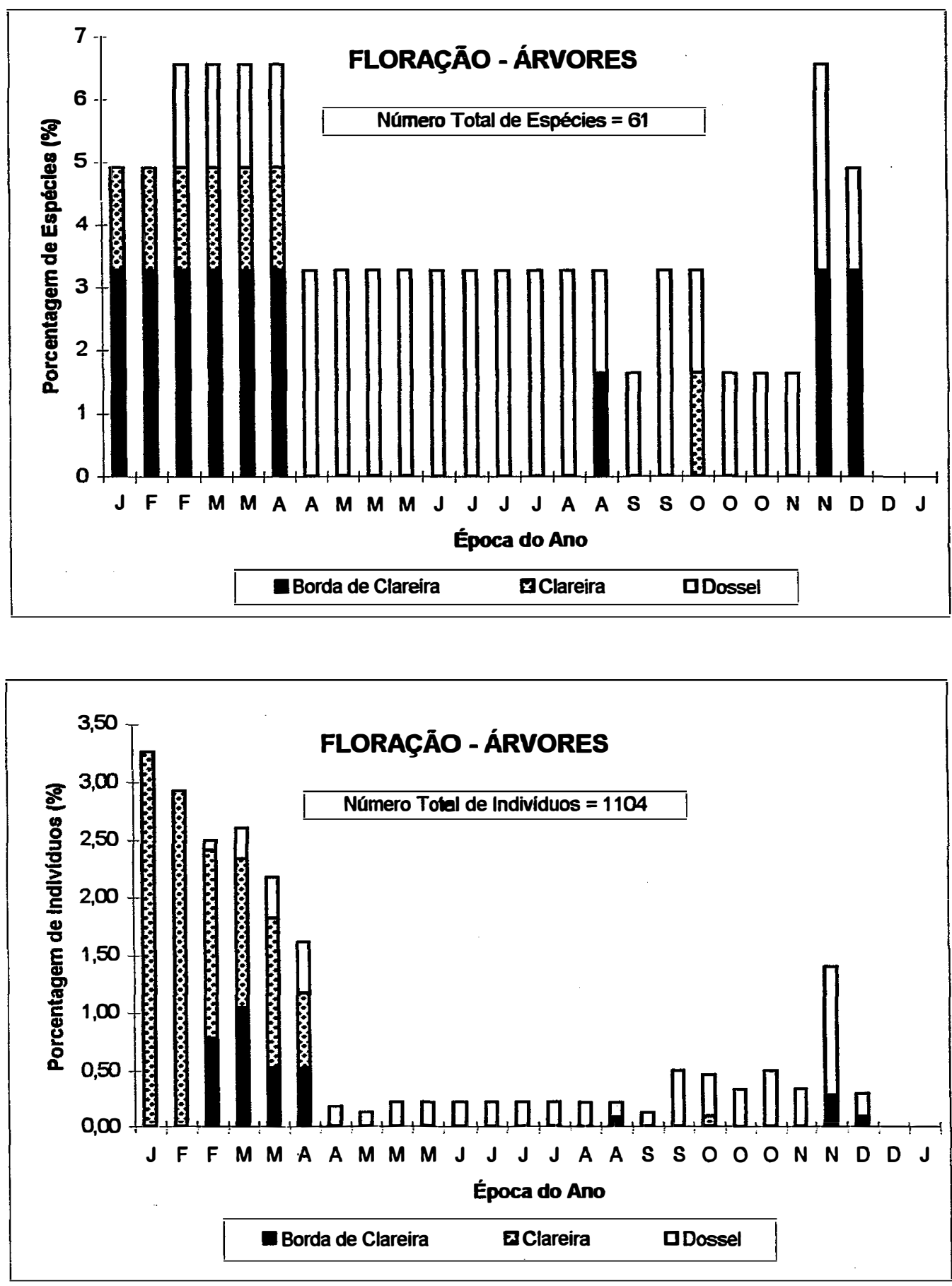

Figura 15 - Padrão de floração das espécies arbóreas (borda de clareira, clareira e dossel) da Mata da Bica, Botucatu-SP, para o ano de 1996; expresso em Porcentagem de Espécies e Porcentagem de Indivíduos em floraçạo por quinzena. As quinzenas estão represntadas pelas iniciais de seus meses. 

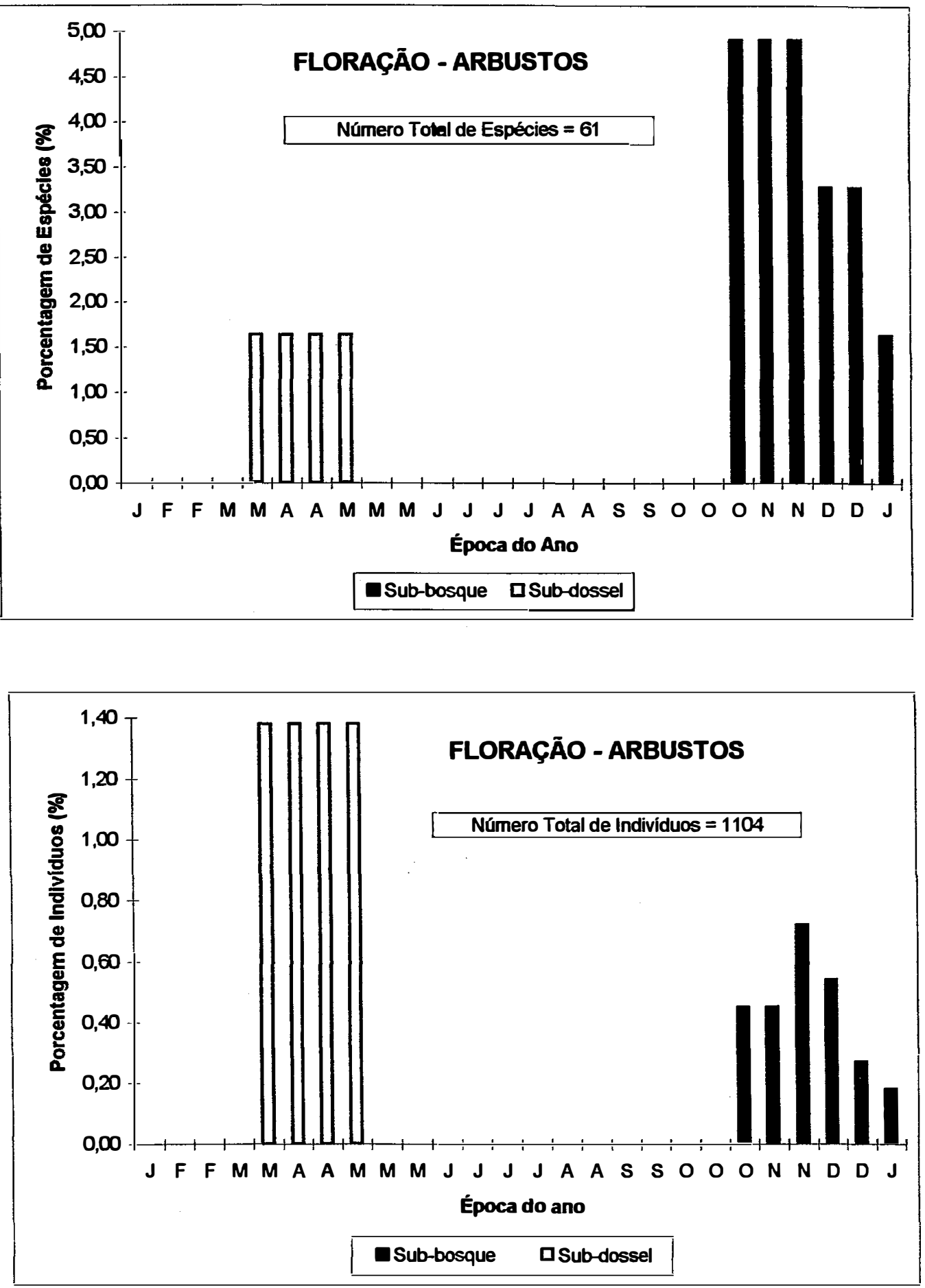

Figura 16 - Padrão de floração das espécies arbustivas (sub-bosque e sub-dossel) da Mata da Bica, Botucatu-SP, para o ano de 1996; expresso em Porcentagem de Espécies e Porcentagem de Individuos em floração por quinzena. As quinzenas estão representadas pelas iniciais de seus meses. 
Considerando a freqüência de indivíduos florescendo na comunidade, o incremento ocorreu no mesmo período mas com intensidade bem menor no segundo período, quando a maior parte das espécies arbustivas encontravam-se em floração. Conforme observado na Figura 16, há uma diferenciação muito nítida no comportamento das espécies e indivíduos de sub-bosque e de sub-dossel. As espécies de sub-bosque são responsáveis pelo segundo e mais intenso período de floração e as espécies de sub-dossel pelo primeiro período.

Os períodos de maior floração para as espécies de lianas foram do início de março a meados de maio atingindo $62 \%$ das espécies, e do início de outubro ao início de dezembro com $20 \%$ das espécies em flor (Figura 17).

A freqüência do florescimento das lianas na comunidade, expressa por porcentagem de parcelas com a presença de lianas nesta fenofase, apresenta um comportamento semelhante porém com picos mais acentuados no final de março (Figura 17).

Embora existam espécies de árvores ou arbustos com flores o ano todo neste fragmento, a sua freqüência de ocorrência na comunidade é muito baixa, nunca ultrapassando $5 \%$ do total de indivíduos. De abril a outubro este valor não ultrapassa a $0,5 \%$. Por outro lado, a ocorrência de lianas com flores fica em torno de 5 a $8 \%$ na época mais crítica, de maio a setembro, e chega a variar de $20-75 \%$ de fevereiro a abril (Anexo 5).

\subsubsection{Frutificação}

Para as espécies arbóreas da comunidade, foram observadas duas épocas de maior frutificação. A primeira delas foi do início de março até o início de abril, no final da estação chuvosa. A outra foi do final de maio ao final de outubro durante a estação seca, atingindo o máximo de $15 \%$ das espécies da comunidade no início de outubro (Figura 18). A frutificação na estação chuvosa foi mais intensa nas espécies de clareira. Já a ocorrência do evento na estação seca foi influenciada pelas espécies de borda de clareira e de dossel.

Analisando a porcentagem de indivíduos frutificando, o mesmo padrão foi observado, mas com menor intensidade. A frutificação chegou a atingir no máximo $4 \%$ 


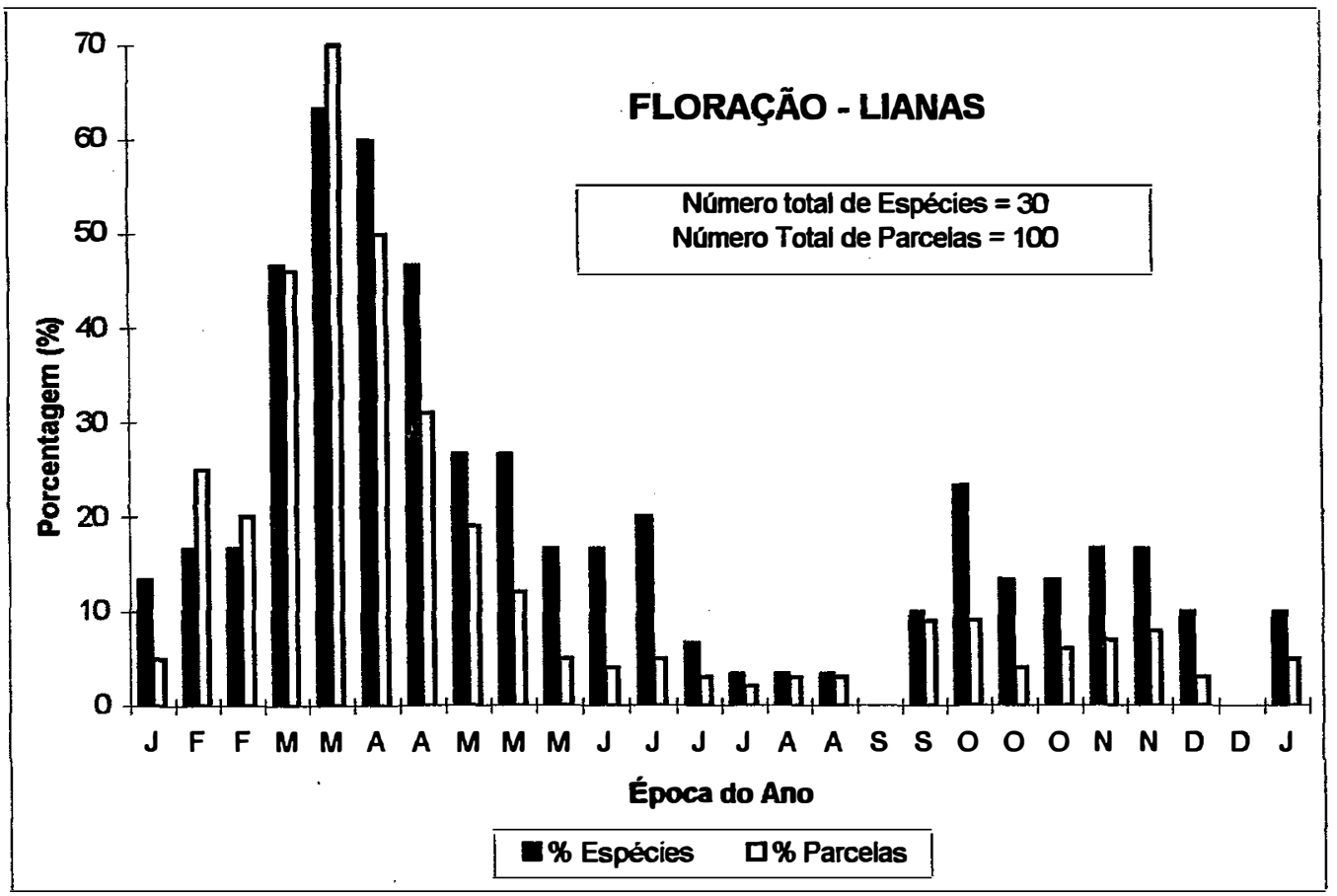

Figura 17 - Padrão de floração das espécies de lianas da Mata da Bica, BotucatuSP, para 0 ano de 1996; expresso em Porcentagem de Espécies e Porcentagem de Parcelas com a presença de lianas em floração por quinzena. As quinzenas estão representadas pelas iniciais de seus meses. 

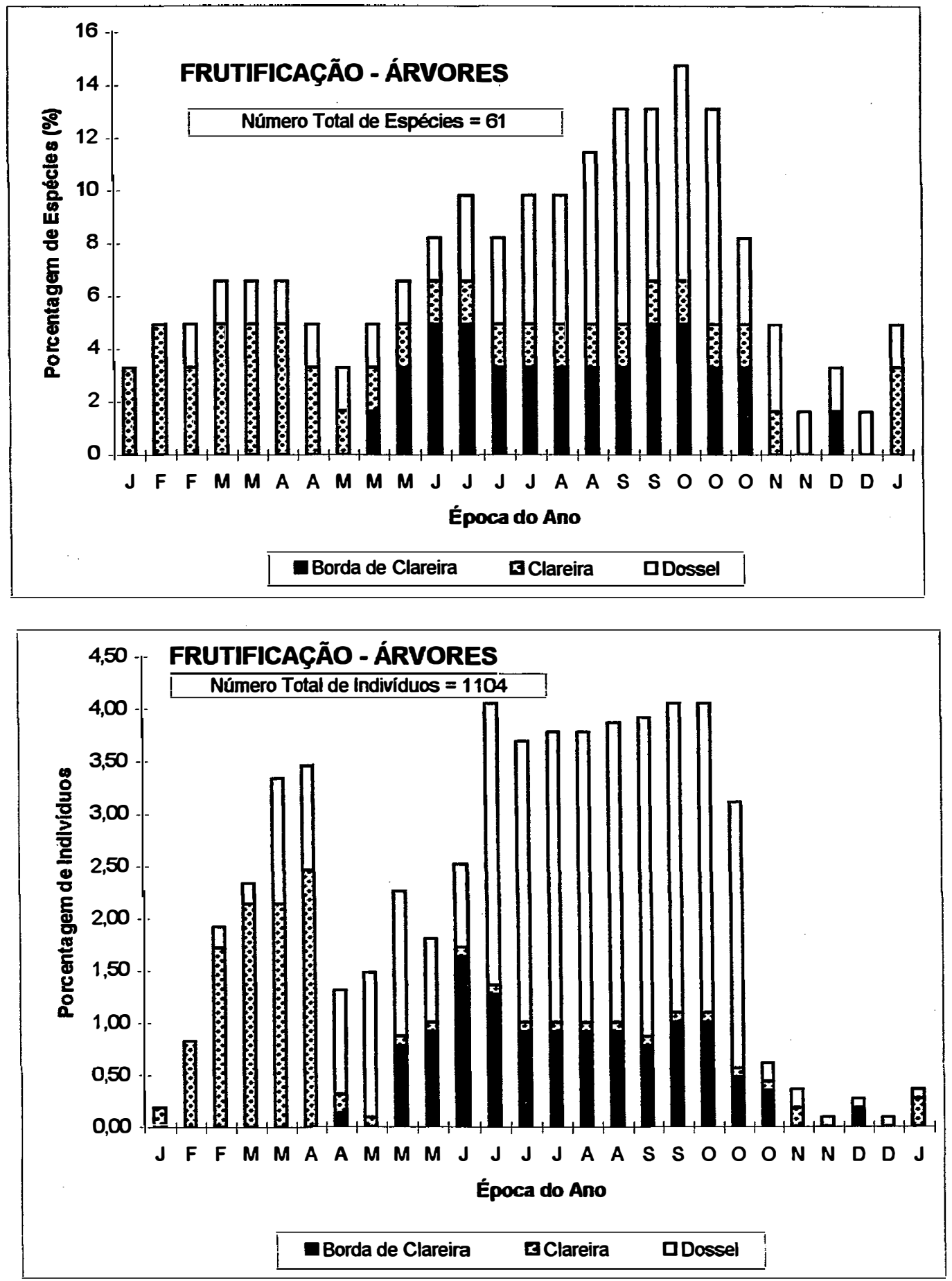

Figura 18 - Padrão de frutificação das espécies arbóreas (borda de clareira, clareira e dossel) da Mata da Bica, Botucatu-SP, para o ano de 1996; expresso em Porcentagem de Espécies e Porcentagem de Indivíduos em frutificação por quinzena. As quinzenas estão representadas pelas iniciais de seus meses. 
dos indivíduos, mesmo no período de transição para a estação chuvosa, quando um maior número de espécies estavam frutificando.

Para as espécies arbustivas foi observado um pico de frutificação do início de março ao início de abril, atingindo pouco mais de $8 \%$ das espécies da comunidade (Figura 19). Durante o restante do ano a frutificação foi bem irregular. Esta irregularidade é arribuída basicamente às espécies de sub-bosque uma vez que as espécies de sub-dossel frutificaram na estação chuvosa.

A porcentagem de indivíduos frutificando na comunidade foi maior no início e final de janeiro atingindo $3 \%$ dos indivíduos da comunidade. Durante o resto do ano este valor não passou de $0,5 \%$. $O$ pico no início de janeiro foi atribuído aos indivíduos de espécies de sub-bosque e o pico de final de janeiro aos de sub-dossel.

Para as espécies de lianas a frutificação apresentou um período de maior frutificação que vai do final de fevereiro ao início de setembro, com uma baixa no final de abril. O pico de frutificação foi em meados de março chegando a atingir mais de $20 \%$ das espécies (Figura 20).

A frequêencia de lianas frutificando na comunidade apresentou um comportamento unimodal com uma época de maior frutificação que vai de meados de maio até final de julho durante o início da estação seca, atingindo pouco mais de $20 \%$ das parcelas nos meses de maior produção. É importante salientar que no início da estação seca (maio), cerca de $2 \%$ dos indivíduos arbóreos e arbustivos estavam frutificando, enquanto nas lianas esta proporção chegou a $20 \%$ (Anexo 6).

\subsubsection{Brotamento}

Com as primeiras chuvas, que vão dar início a estação chuvosa (Figura 6), há um incremento no brotamento tanto para porcentagem de espécies arbóreas quanto para porcentagem de indivíduos arbóreos (Anexo 7).

Para porcentagem de espécies, este incremento chega a atingir $59 \%$ das espécies em outubro e início de novembro, quando começa a declinar gradativamente. Já para a porcentagem de indivíduos, há um pico no início de outubro atingindo cerca de $37 \%$ da comunidade e já começa a declinar.

Para as espécies de borda de clareira e de dossel o declínio da brotação é mais suave do que para as espécies de clareira. Se considerarmos a freqüência desta 

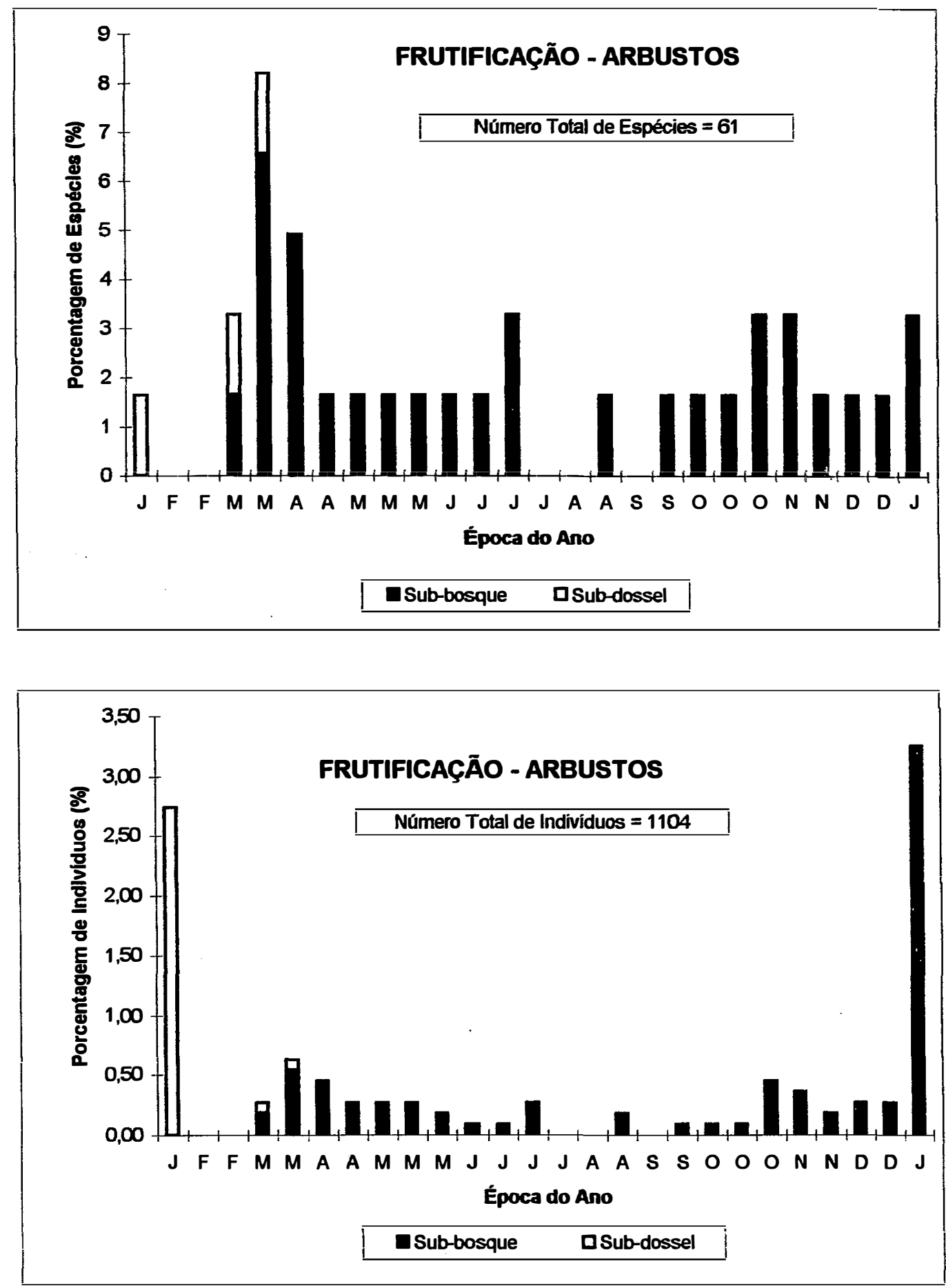

Figura 19 - Padrão de frutificação das espécies arbustivas (sub-bosque e subdossel) da Mata da Bica, Botucatu-SP, para o ano de 1996; expresso em Porcentagem de Espécies e Porcentagem de Individuos em frutificação por quinzena. As quinzenas estão representada pelas iniciais de seus meses. 


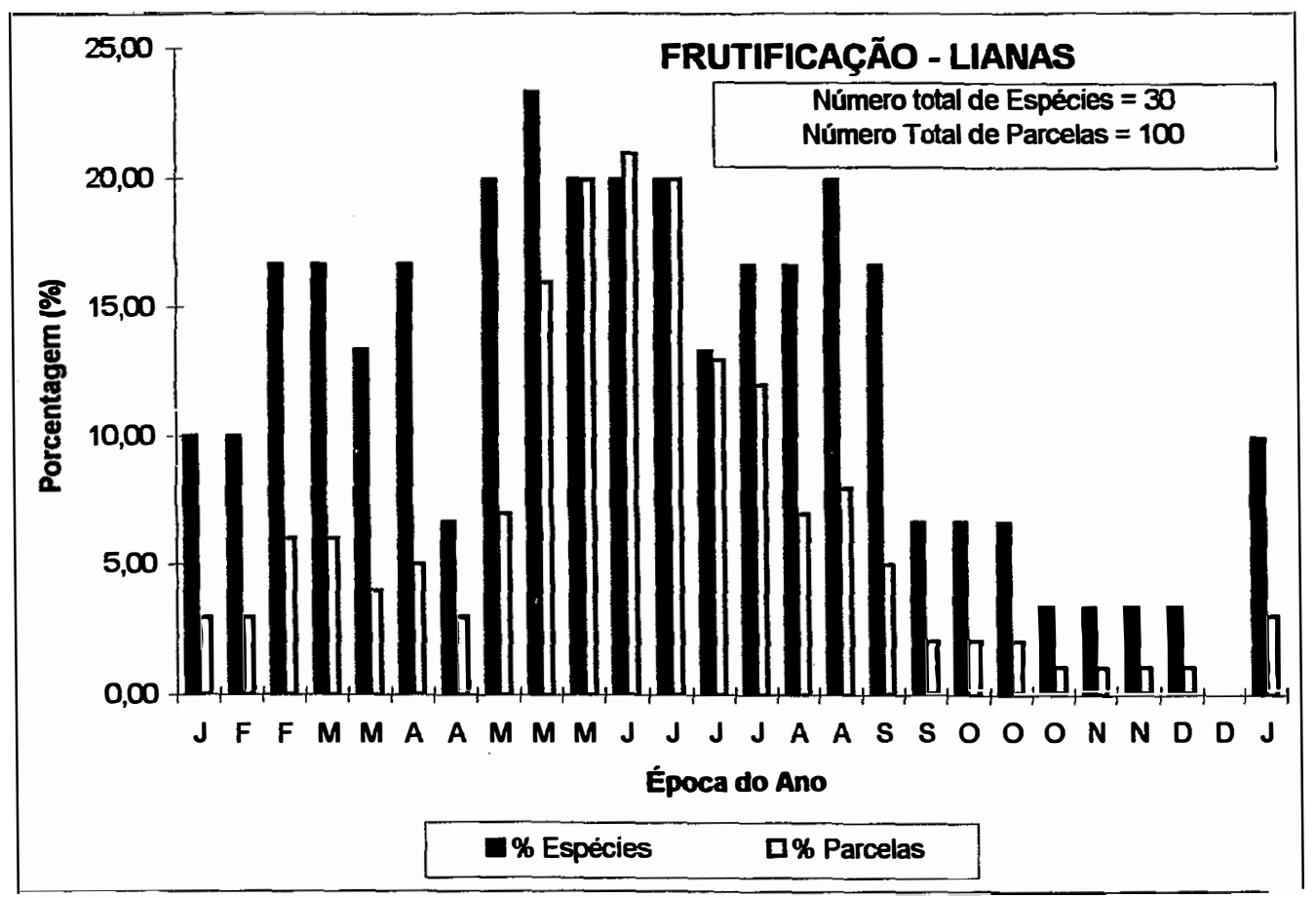

Figura 20 - Padrão de frutificação das espécies de lianas da Mata da Bica, Botucatu-SP, para o ano de 1996; expresso em Porcentagem de Espécies e Porcentagem de de Parcelas com a presença de lianas em frutificação por quinzena. As quinzenas estão representadas pelas iniciais de seus meses. 
fenofase , o padrão da comunidade é fortemente influenciado pelo padrão dos indivíduos de espécies de dossel .

Há também um incremento no brotamento com as primeiras chuvas que vão dar início à estação chuvosa, tanto para porcentagem de espécies arbustivas quanto para porcentagem de indivíduos arbustivos.

Para porcentagem de espécies este incremento atinge cerca de $30 \%$ das espécies, mantendo-se constante até o início de dezembro quando começa a declinar gradativamente. Este padrão é influenciado pelas espécies de sub-bosque. Já para a porcentagem de indivíduos este incremento chega a atingir $50 \%$ dos indivíduos da comunidade, declinando bruscamente a partir do início de dezembro. Este padrão é fortemente influenciado pelos indivíduos de sub-dossel.

\subsubsection{Queda de folhas}

A época de maior queda de folhas tanto para espécies quanto para indivíduos arbóreos foi do final de julho à metade de setembro. Para porcentagem de espécies este incremento chega a atingir $60 \%$ das espécies da comunidade no final de agosto. Já para porcentagem de indivíduos este incremento não passa de $25 \%$ dos indivíduos da comunidade neste mesmo período que coincide com a época mais seca do ano (Anexo 8).

Foi observada uma maior porcentagem de espécies de borda de clareira e de dossel perdendo folhas. As espécies de clareira contribuíram com no máximo $4 \%$ dos indivíduos nesta fenofase. Para a porcentagem de espécies o comportamento foi praticamente o mesmo.

$\mathrm{O}$ incremento na queda de folhas, para as espécies e indivíduos arbustivos, ocorreu no mesmo período das árvores atingindo pouco mais de $25 \%$ das espécies e $40 \%$ dos indivíduos da comunidade. Para porcentagem de espécies a maior contribuição foi das espécie de sub-bosque. Já para porcentagem de indivíduos, as espécies de sub-dossel foram as que mais contrubuíram. 


\subsubsection{Fases de desenvolvimento do mosaico florestal}

Para as espécies arbóreas, o florescimento durante a estação seca (maiosetembro) teve a contribuição das três fases praticamente na mesma proporção (Figura 21). De janeiro a abril, durante a estação chuvosa, foram as fases de clareira e construção que mais contribuíram. Cabe lembrar que o incremento do florescimento durante esta época do ano se deve principalmente às espécies de borda de clareira (Figura 15)

O segundo pico de florescimento das espécies arbóreas no final de novembro teve a contribuição da fase madura com pouco mais de 20 indivíduos e da fase de construção com 10 indivíduos. Este pico é influenciado pelas espécies de borda de clareira e dossel (Figura 15). A contribuição da fase de clareira foi insignificante nesse período de floração.

No florescimento das espécies arbustivas foram as fases madura e de clareira que mais contribuíram (Figura 22). Para as espécies de sub-dossel (Figura 16) a maior contribuição foi da fase madura com cerca de 65 indivíduos com flores seguido da fase de clareira com aproximadamente 30 indivíduos. Para as espécies típicas de sub-bosque, mesmo a freqüência sendo bem baixa a maior contribuição foi da fases madura.

Para as lianas, no periodo de maior florescimento (março-abril) encontramos a contribuição equitativa das três fases (Figura 23). Com o início da estação seca observamos que a contribuição da fase de clareira foi aumentando em termos proporcionais até chegar nos meses de julho e agosto onde a floração foi garantida exclusivamente por esta fases. Esta fases também foi responsável pelo início do segundo período de maior floração.

Quanto a frutificação das espécies arbóreas e arbustivas, a contribuição das três fases foi equilibrada. No caso das lianas, no período de maior produção de frutos, foi a fase de clareira que deu a maior contribuição. Além disso, esta fase foi exclusivamente responsável pela frutificação das lianas no período que vai do final de abril ao início de maio e do final de outubro ao início de dezembro (Figura 24).

$\mathrm{Na}$ comunidade correspondente à fase de clareira, a floração de árvores (final de janeiro ao início de abril) e arbustos (final de março ao início de maio) apresentaram um mesmo padrão de ocorrência na comunidade. Para estas duas formas de vida houve uma sobreposição do florescimento do final de março ao início de abril. A floração durante a estação seca e na transição para estação chuvosa foi garantida pelas lianas e por pouquíssimo indivíduos arbóreos (menos de 5) (Anexo 9). 


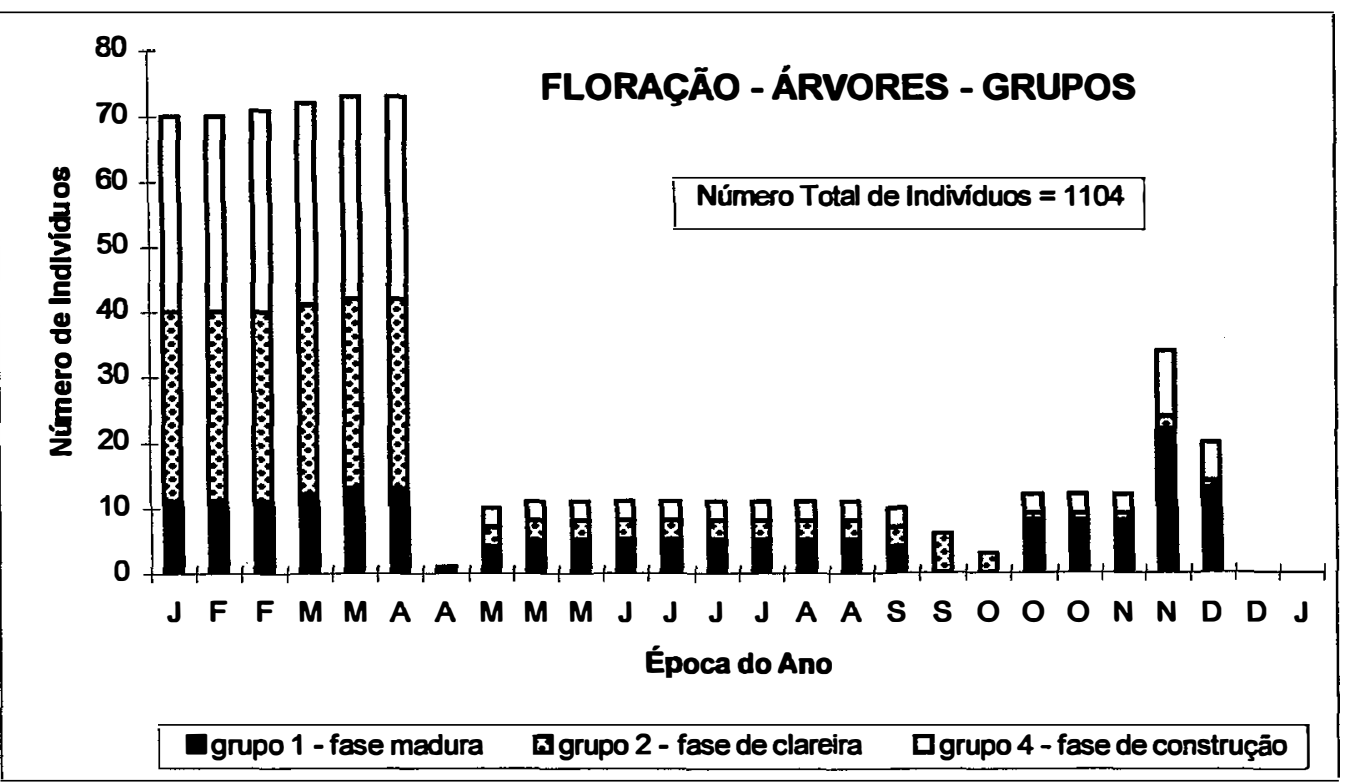

Figura 21 - Padrão de floração das espécies arbóreas dentro de cada grupo de parcelas na Mata da Bica, Botucatu-SP, para o ano de 1996; expresso em Número de Indivíduos em floração por quinzena. As quinzenas estão representada pelas iniciais de seus meses.

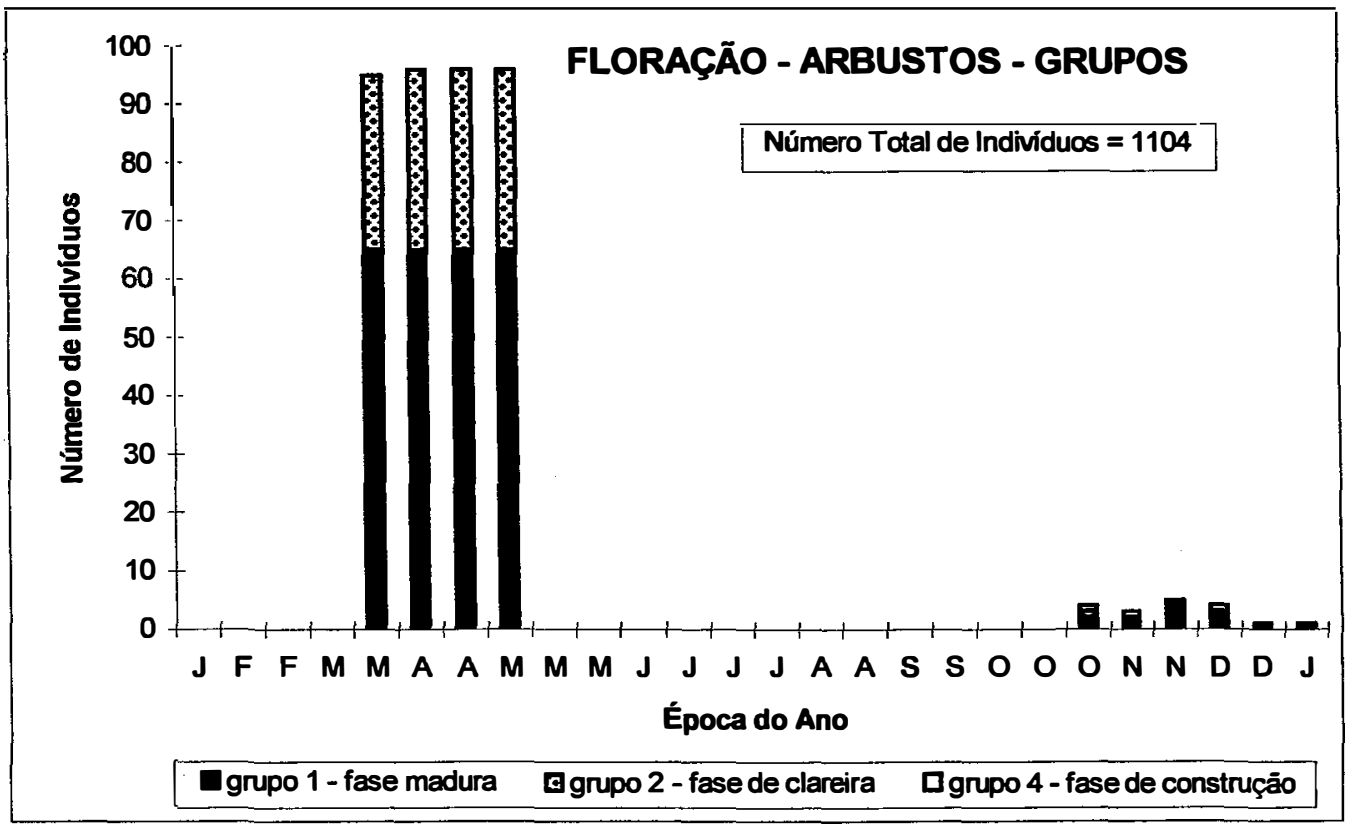

Figura 22 - Padrão de floração das espécies arbustivas (sub-bosque e sub-dossel) dentro de cada grupo de parcelas na Mata da Bica, Botucatu-SP, para o ano de 1996; expresso em Número de Indivíduos em floração por quinzena. As quinzenas estão representadas pelas iniciais de seus meses. 


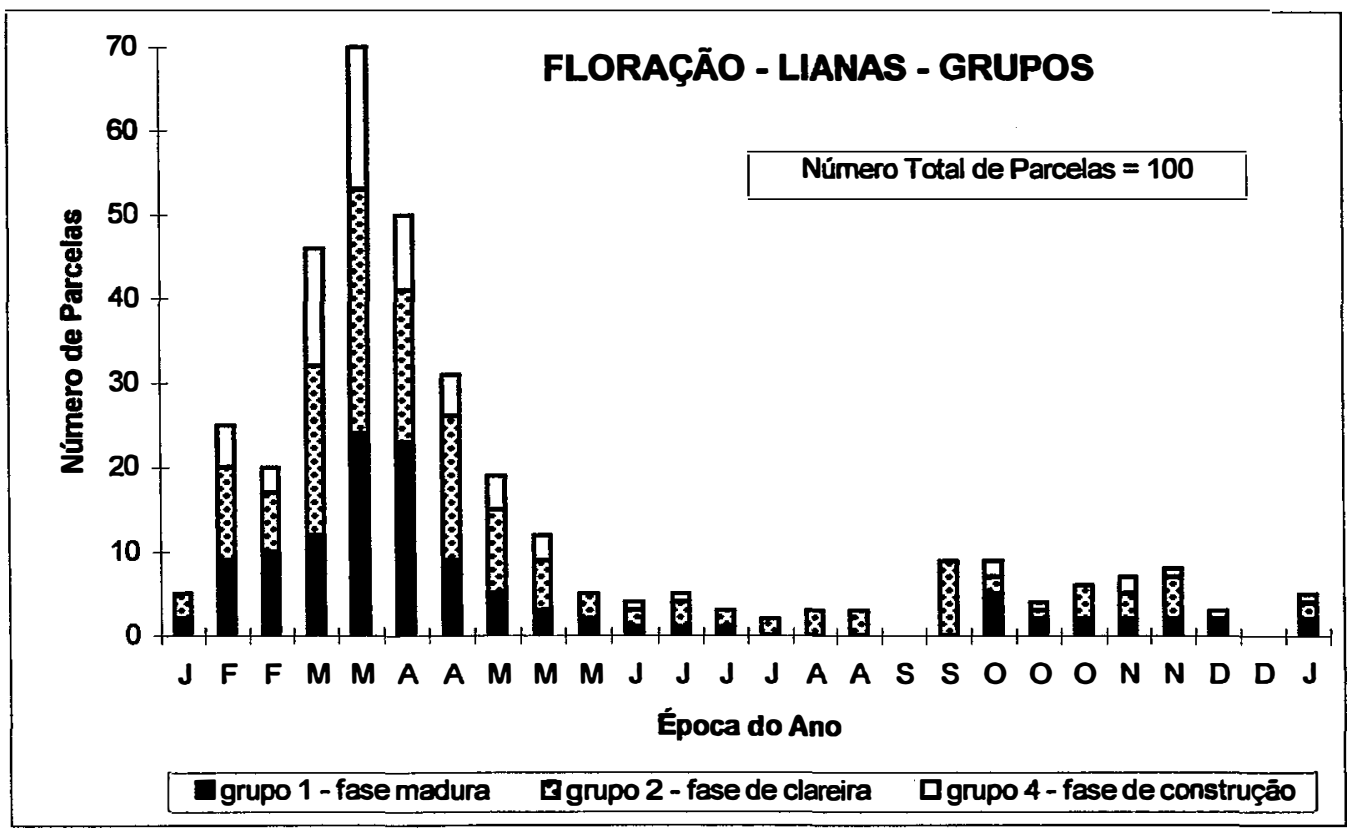

Figura 23 - Padrão de floração das espécies de lianas dentro de cada grupo de parcelas na Mata da Bica, Botucatu-SP, para o ano de 1996; expresso em Número de Parcelas com a presença de lianas em floração por quinzena. As quinzenas estão representadas pelas iniciais de seus meses. 


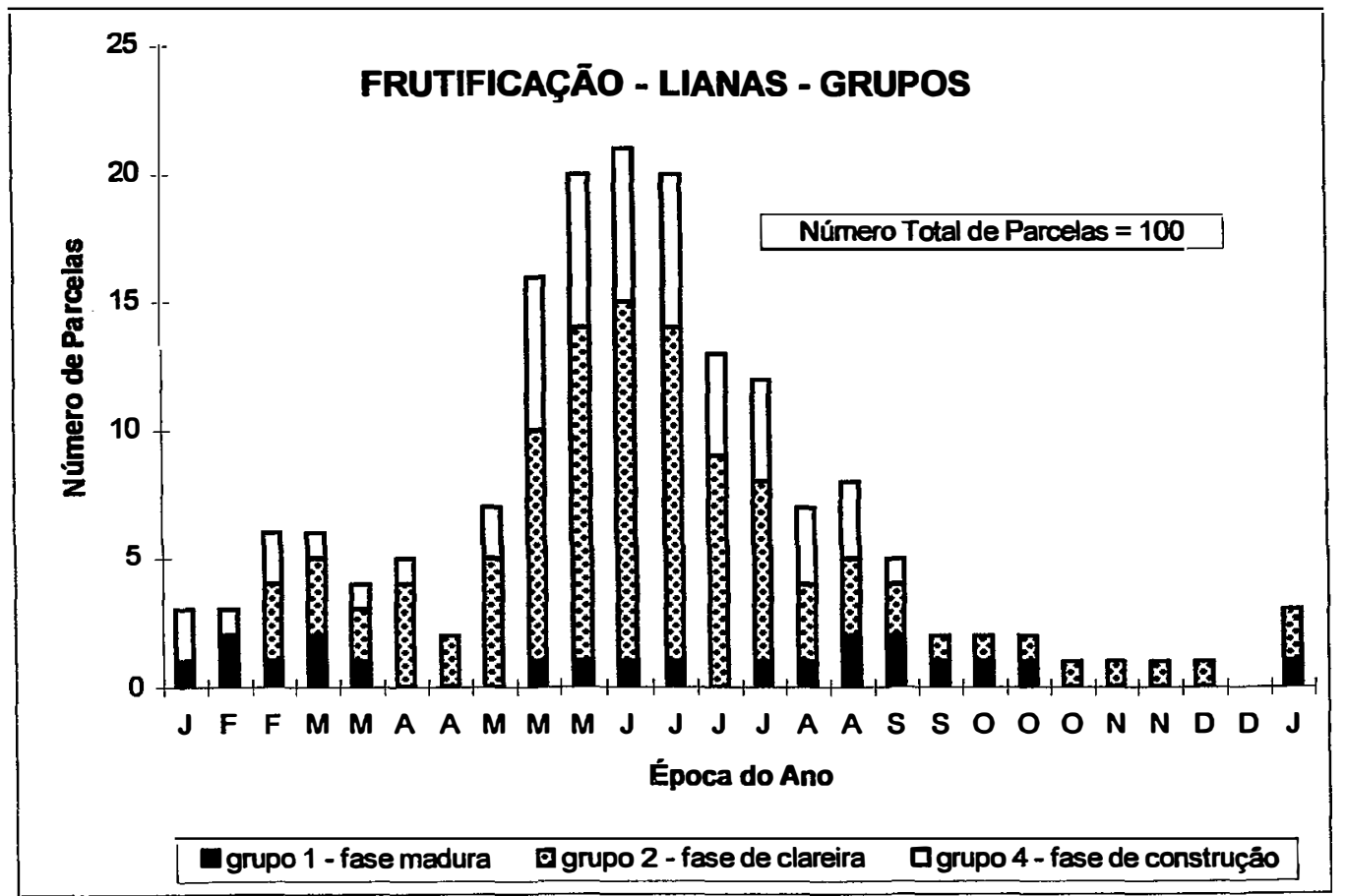

Figura 24 - Padrão de frutificação das espécies de lianas dentro de cada grupo de parcelas na Mata da Bica, Botucatu-SP, para o ano de 1996; expresso em Número de Parcelas com a presença de lianas em frutificação por quinzena. As quinzenas estão representadas pelas iniciais de seus meses. 
Para a comunidade correspondente à fase de construção, os arbustos não tiveram praticamente nenhuma influência no padrão de florescimento da comunidade, sendo este determinado principalmente pelas espécies arbóreas.

Quando comparamos o padrão fenológico encontrado para a comunidade correspondente à cada fase de desenvolvimento do mosaico florestal (Figura 25) observamos que, na fase madura, o pico de florescimento para os arbustos (final de março ao início de maio) difere daquele apresentado para as árvores (novembro), mostrando assincronia entre estas duas formas de vida. Nesta comunidade o pico de florescimento dos arbustos coincidiu com o das lianas, com exceção do início de outubro onde foi observado um pequeno pico de florescimento para as lianas.

Quando observamos o padrão de frutificação de cada fase de desenvolvimento do mosaico florestal (Figura 26), verificamos que a influência das lianas no padrão da comunidade é maior na fase de clareira, intermediária na fase de construção, e muito pequena na fase madura. $O$ padrão de frutificação das espécies arbóreas e arbustivas foi o mesmo nas três fases variando em intensidade (Anexo 10). Estas formas de vida apresentaram maior influência nas comunidades correspondentes à fase madura, intermediária na fase de construção, e pequena na fase de clareira. 

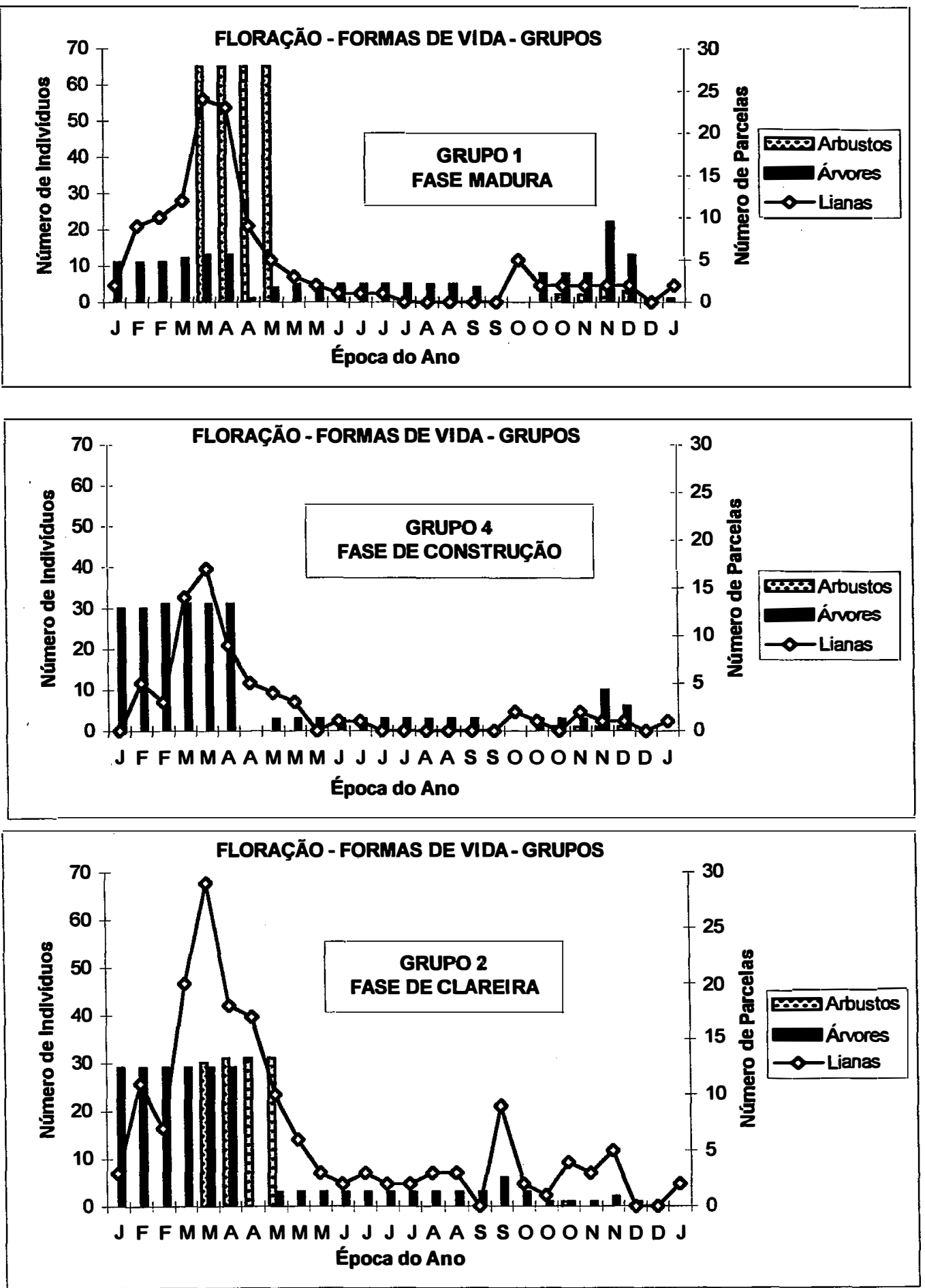

Figura 25 - Padrão de floração da comunidade (árvores, arbustos e lianas) para cada grupo de parcelas na Mata da Bica, Botucatu-SP, para o ano de 1996; expresso em Número de Indivíduos (árvores e arbustos) e Número de Parcelas (lianas) por quinzena. As quinzenas estão representadas pelas iniciais de seus meses. 

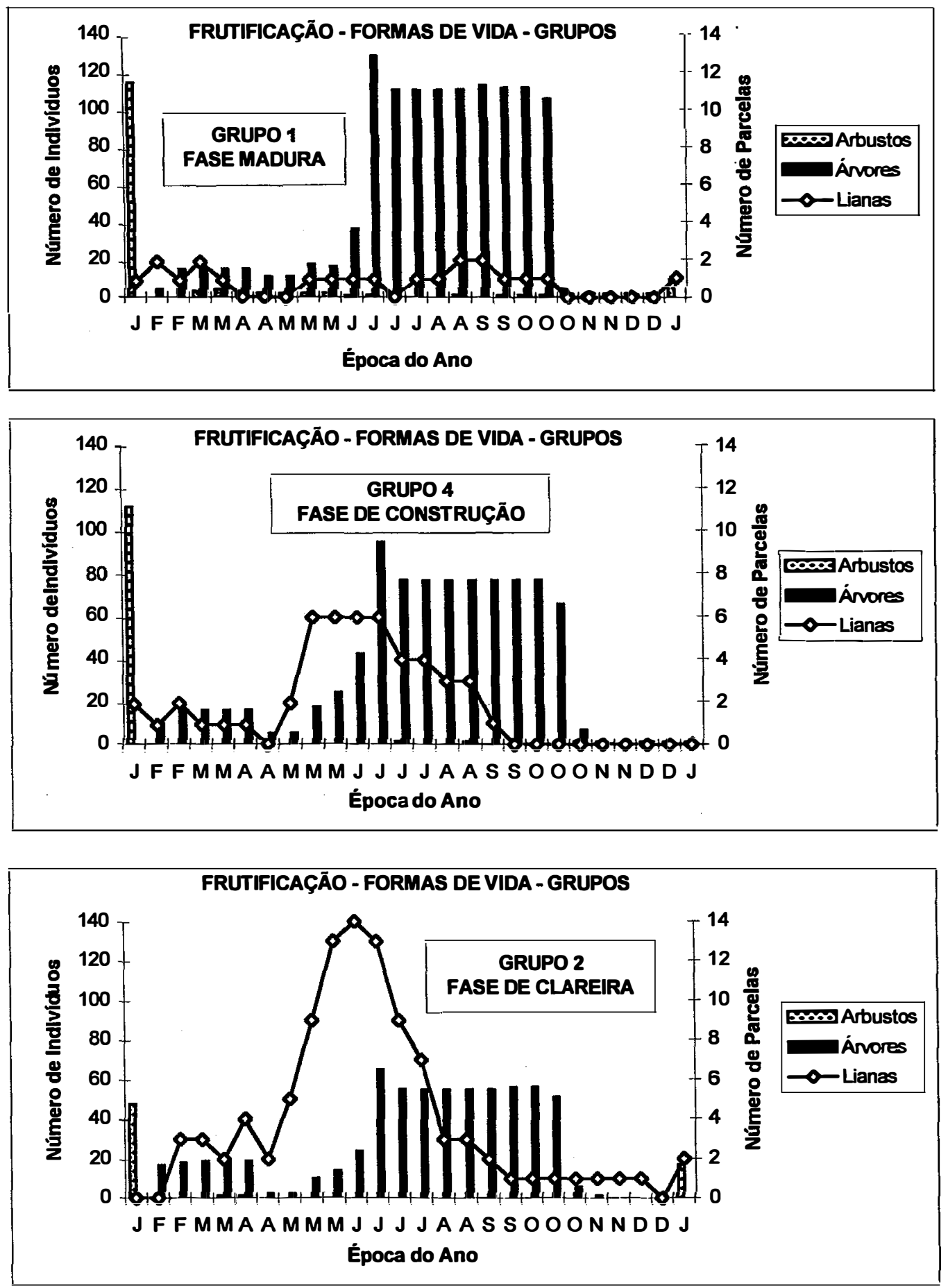

Figura 26 - Padrão de frutificação da comunidade (árvores, arbustos e lianas) para cada grupo de parcelas na Mata da Bica, Botucatu-SP, para o ano de 1996; expresso em Número de Indivíduos (árvores e arbustos) e Número de Parcelas (lianas) por quinzena. As quinzenas estão representadas pelas iniciais de seus meses. 


\section{DISCUSSÃO}

\subsection{Estrutura}

Silva Filho \& Engel (1993) trabalhando no mesmo fragmento, e Gabriel (1990) trabalhando em uma mata mesófila semidecídua de encosta no mesmo município, apresentaram também as familias Meliaceae, Apocynaceae e Fabaceae como as mais numerosas.

O levantamento fitossociológico realizado em um trecho de Floresta Estacional Semidecidual, na Reserva de Santa Genebra, em Campinas - SP, apresentou as familias Meliaceae, Rubiaceae e Apocynaceae como as mais numerosas, destacando a contribuição das espécies Trichilia claussenii e Aspidosperma polyneuron. Neste estudo, a familia de maior riqueza foi a Myrtaceae, ressaltado que se fosse adotado o sistema de Engler, a familia Leguminosae ficaria também em primeiro lugar como na maioria dos trabalhos em matas de planalto do Estado de São Paulo (Rodrigues et al., submetido).

$\mathrm{O}$ grande número de indivíduos apresentado por Trichilia claussenii e Aspidosperma polyneuron é similar aqueles encontrados em alguns levantamentos no Estado de São Paulo. Bernacci \& Leitão Filho (1996), comparando três formações florestais no município de Campinas-SP, encontraram uma abundância para Trichilia clausseni de pelo menos 200 indivíduos/ha nas três formações, chegando a atingir 294 individuos/ha. Para Aspidosperma polyneuron os valores encontrados foram 15, $111 \mathrm{e}$ 217 indivíduos/ha.

Dentre as espécies que apresentaram baixa densidade encontramos algumas de início de sucessão, que em função do método foram amostradas com baixa densidade e uma espécie secundária tardia que pode ser um indicativo de espécie rara, necessitando mais estudos.

Em relação ao valor de importância resultados semelhantes foram apresentados por Silva Filho \& Engel (1993). Na Reserva de Santa Genebra, a 
Aspidosperma polyneuron ficou em primeiro lugar, seguida também da Trichilia claussenii.

O fato da Urera baccifera estar entre as dez espécies mais importantes se deve principalmente à ocorrência de grandes clareiras naturais no interior do fragmento associada à alta fertilidade dos solos da Mata da Bica. Na Santa Genebra, onde a porcentagem de espécies pioneiras é semelhante e a concentração de nutrientes no solo é menor, esta espécie ocupa a trigésima primeira posição na escala de valor de importância, ocorrendo também em outros dois fragmentos no município de Campinas (Rodrigues et al., submetido; Bernacci \& Leitão Filho, 1996). Já no Município de Itirapina, sob mancha de solo de origem basáltica, esta espécie assumiu a primeira posição (KotchetkoffHenriques \& Joly, 1994).

O valor para diversidade $\left(\mathrm{H}^{\prime}\right)$ encontrado neste trabalho pode ser considerados baixo quando comparados com aqueles encontrados em outros remanescentes florestais do Estado de São Paulo, que de acordo com Leitão Filho (1987) podem variar de 3,16 a 4,29. Numa floresta em estágio inicial de sucessão este índice alcançou 3,73 (Gandolfi et al. 1995). O baixo valor de equabilidade significa que na comunidade analisada existem populações contribuindo desigualmente para a elaboração do índice de diversidade (Ivanauskas, 1997). Estes resultados se devem basicamente à grande influência que Aspidosperma polyneuron, Trichilia claussenii e Trichilia catigua exerceram na estrutura da comunidade; porém mesmo na Reserva de Santa Genebra, onde também houve grande influência de determinadas espécies na estrutura da comunidade, o índice de diversidade $\left(\mathrm{H}^{\prime}\right)$ foi de 3.2.

Das 167 espécies arboreas e arbustivas encontradas em um levantamento realizado em uma floresta estacional semidecidual no município de Guarulhos-SP, 41 espécies $(24,5 \%)$ foram classificadas como pioneiras, 43 (25,8\%) como secundárias iniciais, 51 (30,5\%) como secundárias tardias e 32 (19,2\%) sem classificação (Gandolfi et al., 1995). Embora tenha sido constatada uma predominância das secundária tardias isoladamente, foram as espécies de início de sucessão (pioneiras + secundárias iniciais) que compuseram a maioria da flora encontrada (84 espécies ou 50,3\%), sendo esta floresta enquadrada pelos autores numa condição jovem em termos sucessionais ou com a presença de trechos bastante jovens.

Neste trabalho as espécies de início de sucessão (pioneiras + secundárias iniciais) somam 50,8 \% do total de espécies, ultrapassando os $45,9 \%$ das secundárias tardias. Neste caso poderíamos enquadrar este trecho de floresta numa condição 
semelhante em termos sucessionais quando comparada com a área estudada por Gandolfi et al. (1995).

A porcentagem de espécies por grupo ecológico no trecho estudado também se aproxima da situação encontrada para a Reserva de Santa Genebra, onde a proporção foi de $41,6 \%$ de espécies secundárias tardias, 36,7\% de secundárias iniciais, $12,9 \%$ de pioneiras e $8 \%$ sem caracterização sucessional (Rodrigues et al., submetido). Os autores relacionam o predomínio de espécies de final de sucessão ao bom estado de preservação do trecho estudado. A porcentagem também elevada de espécies secundárias iniciais foi explicada pelos autores através do histórico de fragmentação, perturbação e deciduidade periódica de uma certa porcentagem de espécies. Esta deciduidade proporcionaria um aumento periódico da luminosidade interior, favorecendo esse grupo sucessional.

Os resultados obtidos através da caracterização do mosaico florestal mostram que em termos de desenvolvimento sucessional trata-se de um trecho bastante heterogênio, onde $55 \%$ da área se encontra em fase de clareira e construção e apenas $33 \%$ em fase madura. A porcentagem de espécies de início de sucessão $(50,8 \%)$ se aproxima da porcentagem da área em fases iniciais de desenvolvimento do mosaico florestal (55\%). Este fato nos leva a crer que a composição florística pode nos dar uma idéia do estágio de desenvolvimento sucessional de uma determinada área.

A utilização de parâmetros fitossociológicos como Área Basal, Densidade, e Densidade por Grupo Ecológico veio reforçar os resultados obtidos a partir da análise de agrupamento, mostrando que a fitossociologia pode ser uma importante ferramenta para a caracterização do mosaico florestal.

O método da interceptação de linhas e inventário descrito por Torquebiau (1986), para o mapeamento das eco-unidades propostas por Oldeman (1983), vem sendo utilizado no Brasil por alguns pesquisadores (Engel \& Prado, 1992; Cardoso-Leite, 1995; Oliveira, 1997); porém as dificuldades apresentadas na aplicação deste método em campo exige muito mais tempo e experiência.

\subsection{Fenologia}

Estudos fenológicos de comunidades têm apresentado tipicamente a soma de espécies florescendo, frutificando e brotando em um dado momento. Esta soma, segundo Bullok \& Solís-Magallanes (1990), inclui populações ativas de aproximadamente 5\% dos 
indivíduos. A baixa frequiência de ocorrência das fenofases encontrada na Mata da Bica vem reforçar os resultados obtidos pelos autores.

Segundo Bullok \& Solís-Magallanes (1990), há uma variação entre os indivíduos arbóreos na quantidade de flores e frutos produridos e ainda na freqüência de reprodução. Esta variação pode ser atribuída em parte às diferenças físicas dos sítio, vizinhança e efeito de animais.

Heideman (1989), estudando diferentes indicadores para representar o padrão fenológico, concluiu que a porcentagem de plantas também não é um bom indicador de abundância, quando comparado com outros indicadores como número de flores por hectare e índice de volume de flores por hectare.

Espécies arbóreas de uma floresta estacional na Serra do Japi estudada por Morellato et al. (1989) floresceram na estação transicional (setembro-outubro), com um pico de floração em novembro. Resultado semelhante foi encontrado por Spina (1997) em uma floresta de brejo na região de Campinas -SP e por Matthes (1980) para espécies arbóreas de planalto do Bosque dos Jequitibás. Estes resultados se assemelham aqueles encontrados na Mata da Bica, com exceção do primeiro pico de floração de fevereiro à abril, que não foi observado por estes autores. $O$ incremento da floração neste período se deu por parte das espécies típicas de clareira (Figura 15), que foram contempladas neste trabalho através do tipo de amostragem utilizada (área contínua no interior de um fragmento).

As espécies arbustivas da floresta de brejo, estudada por Spina (1997), apresentaram seu pico de floração em junho durante a estação seca, mas houve também um incremento de setembro a dezembro. Este incremento no período transicional é semelhante ao padrão encontrado na Mata da Bica para as espécies de sub-bosque.

Opler et al. (1980) encontraram em uma floresta tropical seca na província de Guanacaste, na Costa Rica, um padrão sazonal para o florescimento de arbustos e arvoretas. Na floresta decídua foi observado um pico no início da estação chuvosa. $\mathrm{Na}$ floresta ripária a comunidade de arbustos e arvoretas teve o maior florescimento no final da estação chuvosa. Já em uma formação secundária, dentro da floresta seca, o período de maior floração foi na segunda metade da estação chuvosa com um pico no final desta.

Os mesmos autores estudando uma floresta tropical úmida na província de Heredia (La Selva) não encontraram picos de florescimento para arbustos e arvoretas, havendo uma tendência ao aumento desta fenofase na primeira metade do ano. 
Outros autores estudando três tipos de floresta na província de Monteverde, na Costa Rica (Koptur et al., 1988), observaram maior florescimento dos arbustos e arvoretas no final da estação seca e início da chuvosa. De acordo com estes autores, a sazonalidade da queda de chuva em Monteverde é intermediária, estando entre as florestas tropicais úmidas e secas da Costa Rica. Este fator leva ao florescimento dos arbustos e arvoretas ser mais sazonal em Monteverde, quando comparado com La Selva, e menos sazonal quando comparado com Guanacaste.

Sendo a Mata da Bica uma floresta estacional semidecidual, a sazonalidade encontrada para as espécies arbustivas já era esperada. $\mathrm{O}$ que se percebeu é que os arbustos de sub-bosque florescem em época distinta das arvoretas de sub-dossel, sendo o comportamento dos primeiros semelhante aquele encontrado por Koptur et al. (1988) para o mesmo tipo de floresta.

Morellato (1991), estudando a fenologia de 130 espécies arborescentes da Reserva de Santa Genebra, encontrou dois picos de floração, um em janeiro e outro maior em novembro. Se juntarmos, para efeito comparativo, o padrão das espécies arbóreas e arbustivas encontrados na Mata da Bica teremos dois picos de floração um em março e abril com cerca de $8 \%$ das espécies em floração e outro maior em novembro com cerca de $11,5 \%$ das espécies nesta fenofase. $\mathrm{O}$ incremento da floração de março à abril, neste caso, foi influenciado pela floração das espécies de sub-dossel e das espécies típicas de clareira.

Morellato \& Leitão Filho (1996), estudando 136 espécies de lianas na Reserva de Santa Genebra, encontraram picos de florescimento nos períodos de transição da estação chuvosa para a estação seca e vice-versa.

Kim (1996) analisando a fenologia de 361 espécies de lianas da Mata Attântica, com base em levantamentos realizados em herbários e algumas observações de campo, encontrou um pico de floração em fevereiro e outro em novembro durante a estação chuvosa, além de um terceiro pico menor em julho durante a estação seca.

Spina (1997) também encontrou um pico de floração durante a estação chuvosa no mês de novembro, para as lianas de uma mata de brejo na região de Campinas-SP.

Putz \& Windsor (1987), estudando a fenologia de 43 espécies de lianas na Ilha Barro Colorado, no Panamá, observaram um padrão bimodal de florescimento com dois picos, um no meio da estação seca e outro no meio da estação chuvosa. Croat (1975), trabalhando na mesma região através de levantamento em herbário de cerca de 
150 espécies de lianas lenhosas e 90 de lianas hebáceas, observou um pico de floração no início da estação seca.

A sazonalidade e o comportamento bimodal do padrão de florescimento encontrados na Mata da Bica concordam com resultados obtidos por Morellato \& Leitão Filho (1996), Kim (1996) e Putz \& Windsor (1987). Os picos de floração ocorreram nos períodos transicionais conforme observado por Morellato \& Leitão Filho (1996).

Diferenças encontradas no padrão fenológico nos trabalhos acima podem estar relacionadas à proporção de espécies de lianas zoocóricas e anemocóricas, ou ainda herbáceas e lenhosas. O florescimento de árvores e lianas anemocóricas estudadas por Ibarra-Maríquez et al. (1991) ocorreu na época de menor precipitação para as duas formas de vida. Opler et al.(1991) observaram que trepadeiras herbáceas apresentaram padrão sazonal de florescimento com pico no final da estação chuvosa e início da estação seca. Já as trepadeiras lenhosas foram relativamente não sazonal. Esta não sazonalidade foi atribuída à influência das espécies da familia Bignoniaceae que floresceram praticamente durante todo $o$ ano.

A frutificação das espécies arbóreas estudadas por Morellato et al. (1989) na floresta estacional da Serra do Japi, ocorreu durante todo o ano com maior número de espécies com frutos de julho a setembro e em janeiro e fevereiro. Spina (1997) encontrou também dois picos de frutificação para espécies arbóreas, um mais acentuado em agosto e outro menos acentuado em fevereiro. Na Mata da Bica, os períodos de maior frutificação ocorreram mais para o final das estações, apresentado um pico no final de outubro.

As espécies arbustivas estudadas por Spina (1997) apresentaram um pico de frutificação mais acentuado em junho e dois picos pouco acentuados em setembro e fevereiro. A frutificação de arbustos e arvoretas da floresta tropical úmida estudada por Opler et al. (1980) apresentou uma tendência a ser maior na segunda metade do ano. $\mathrm{Na}$ floresta tropical seca foram observados dois picos de produção de frutos um de fevereiro a abril e outro de agosto a setembro, tanto para a floresta decídua quanto para a floresta ripária. Já em uma formação secundária dentro da floresta tropical seca o pico de frutificação ocorreu de dezembro a abril.

A irregularidade da frutificação das espécies arbustivas da Mata da Bica é similar aos resultados obtidos por Koptur et al. (1988), onde a frutificação das espécies de arbustos e arvoretas também foi menos sazonal que o florescimento. De acordo com 
os autores o maior número de espécies com frutos ocorreu durante a estação chuvosa e início da estação seca.

Se juntarmos, para efeito comparativo, o padrão das espécies arbóreas e arbustivas encontrados no presente trabalho e compararmos com os resultados apresentados por Morellato (1991), para frutificação das espécies arborescentes da Reserva de Santa Genebra, veremos que o comportamento fenológico das espécies foi distinto para as duas áreas. A autora encontrou um incremento na frutificação no final da estação seca adentrando à estação chuvosa e decrescendo gradativamente em direção a estação seca. Já na Mata da Bica este incremento ocorreu nos dois períodos transicionais atingindo cerca de $15 \%$ das espécies no final de março e cerca de $16 \%$ no início de outubro.

O período de maior frutificação das lianas encontrado na Mata da Bica é similar ao de vários estudos realizados com lianas em florestas tropicais, ou seja, ocorreu durante a estação seca. Entretanto, a frutificação no período de fevereiro a abril observada neste estudo difere dos demais e se aproxima dos resultados apresentados por Kim (1996). A autora encontrou um incremento na frutificação nos meses de fevereiro e abril.

Morellato \& Leitão Filho (1996) encontraram um comportamento unimodal para a frutificação das espécies de lianas da Reserva de Santa Genebra com um incremento durante a estação seca.

$\mathrm{Na}$ Ilha Barro Colorado também foram encontrados dois pico de frutificação para lianas, um durante a estação seca e outro menor no final da estação chuvosa (Putz \& Windsor, 1988). No trabalho de Croat (1975) foi observado apenas um pico durante a estação seca com a maturação dos frutos durante ou logo depois do final do florescimento.

A frutificação de trepadeiras herbáceas foi mais sazonal que das trepadeiras lenhosas estudadas por Opler et al. (1991). Os dois grupos apresentaram pico durante a estação seca, sendo as herbáceas no início e as lenhosas no final. Para as espécies herbáceas, a frutificação ocorreu logo após ao florescimento, já para as trepadeiras lenhosas que frutificaram na estação seca o florescimento ocorreu durante a estação chuvosa.

Numa floresta tropical em Veracruz, no México, o estudos de árvores e lianas anemocóricas indicou duas épocas de maior frutificação para as espécies com sementes 
aladas (pterócoras), uma durante a estação seca para árvores e outra na estação chuvosa para lianas (Ibarra-Maríquez et al., 1991).

Na Mata da Bica uma liana da familia Cactaceae (Pereskia aculeata Mill.) apresentou abundante frutificação em pequenas clareiras no interior da mata durante a estação seca. Esta espécie floresce do final de março ao início de julho e frutifica do início de julho ao início de outubro. Frutos imaturos são observados a partir de maio. De acordo com levantamento realizado por Kim (1997), esta espécies foi coletada com flores em abril. Em sua descrição, esta espécies é citada como uma liana lenhosa, com frutos carnosos e comestíveis. Uma espécie do gênero Solanum (Solanaceae), foi observada com frutos no início da estação seca (março-junho). De acordo com a autora as espécies do gênero Solanum são consideradas zoocóricas. Da familia Vitaceae duas espécies do gênero Cissus, também classificadas como zoocóricas (Kim, 1997), frutificaram durante a estação seca uma delas de março-maio e outra de maio-agosto.

De maneira geral, nas florestas tropicais o brotamento ocorre no final da estação seca (Alencar 1994; Jackson 1978; Whitmore 1990). Entretanto, alguns autores sugerem que o brotamento é controlado pelo potencial hídrico das árvores, ou seja, cada árvore irá se desenvolver de acordo com o seu potencial hídrico interno (Reich \& Borchert, 1984).

Morellato et al. (1989), trabalhando em uma floresta mesófila na Serra do Japi observaram um período de produção de folhas novas de agosto à janeiro, com um pico em outubro, atingindo $62,5 \%$ das espécies arbóreas estudadas.

A produção de folhas novas de arbustos e arvoretas, na floresta tropical úmida estudada por Opler et al. (1980), é constante durante o ano. Na floresta tropical seca esta produção é sazonal, ocorrendo no início da estação chuvosa para a floresta decídua e no final desta para a floresta ripária. $\mathrm{Na}$ formação secundária a produção de novas folhas ocorre continuamente durante toda a estação chuvosa.

Koptur et al. (1988) não encontraram padrão sazonal pronunciado para a atividade foliar em arbustos e arvoretas. A maioria das espécies apresentaram um incremento na produção de folhas jovens durante a estação seca.

A sazonalidade na produção de folhas novas, assim como o período de maior produção observados neste trabalho, concorda com os resultados obtidos por Morellato et al. (1989), para éspécies arbóreas, e Opler et al. (1980) para espécies arbustivas em florestas estacionais. 
De acordo com o estudo realizado por Morellato et al. (1989), em floresta mesófila na Serra do Japi, cerca de $70 \%$ das espécies arbóreas observadas perderam suas folhas durante a estação seca e estação transicional, ou seja, de maio a outubro.

A senescência e abscisão das folhas foi contínua para a maior parte das espécies arbustivas e para arvoretas na floresta tropical úmida estudada por Opler et al (1980). Na floresta tropical seca o pico para queda de folhas ocorreu durante o início da estação seca. Para Koptur et al. (1988) a perda de folhas também foi contínua nas espécies observadas.

A perda de folhas durante a estação seca observada na Mata da Bica concorda com os resultados obtidos por Morellato et al. (1989) para espécies arbóreas. Para espécies arbustivas, o padrão sazonal foi semelhante àquele encontrados por Opler et al. (1980) em floresta tropical seca. O fato dos autores terem observado o pico de queda de folhas no início da estação seca pode estar relacionado à metodologia que neste trabalho considerou apenas a presença ou ausência do evento nos indivíduos e não sua intensidade. A intensidade do evento foi considerada através da maior ou menor ocorrência do evento na comunidade.

Embora não tenha sido avaliada a queda de folbas para as lianas, o que se percebeu é que este evento ocorre em menor intensidade para este grupo, necessitando mais estudos. No trabalho realizado por Putz \& Windsor (1997), das 43 espécies de lianas estudadas apenas 2 apresentaram queda de folhas. $\mathrm{O}$ restante foi considerado sempre-verdes.

A diferença da luminosidade no interior de uma floresta estacional semidecidual, em diferentes estações do ano, foi estudada por Bemacci \& Leitão Filho (1996) no município de Campinas-SP. Durante a estação úmida os valores para luminosidade foram significativamente menores do que os obtidos durante a estação seca. Estes autores relacionaram este fato à deciduidade de algumas espécies na época mais seca do ano, ou seja durante o inverno.

Comparando o comportamento fenológico encontrado na Mata da Bica com as características estruturais de cada fase de desenvolvimento do mosaico florestal (Figura 14 e Tabela 2), observamos mais uma vez a dicotomia entre a fase madura e a fase de clareira e uma situação intermediária da fase de construção, agora mais próxima à apresentada pela fase de clareira. Estes resultados mostram que o comportamento fenológico da comunidade varia de acordo com as fases de desenvolvimento do mosaico florestal. 
São poucos os trabalhos de fenologia realizados em florestas tropicais que estudam a influência da sucessão secundária na determinação do padrão fenológico da comunidade (Carabias-Lillo \& Guevara-Sada, 1985). Segundo estes autores a variação do comportamento fenológico de comunidades em diferentes estágios sucessionais está relacionada à variação na composição florística, ou seja, estas áreas apresentam espécies distintas com diferentes estratégias reprodutivas. Gandolfi et al. (1995) sugerem que as características do mosaico sucessional podem condicionar a florística encontrada.

Este fato nos leva a crer que as variações na freqüência, densidade e dominânica das espécies que ocorrem numa escala menor, nas diferentes fase do mosaico florestal, podem ser consideradácomo uma das causas da variação no comportamento fenológico da comunidade uma vez que os indivíduos da mesma espécies tendem a florescer e frutificar no mesmo período. Para testar esta hipótese estudos devem ser conduzidos com o objetivo de comparar o comportamento fenológico de indivíduos da mesma espécies nas diferentes fases de desenvolvimento do mosaico florestal. Além disso, a estrutura populacional de tais espécies em cada fase deve ser avaliada. 


\section{CONSIDERAÇÕES FINAIS}

A comunidade florestal estudada apresentou padrões sazonais para as fenofases queda de folhas, brotamento, floração e frutificação.

Comparando o padrão fenológico encontrado, quando utilizados diferentes indicadores, verificamos que o período de maior diversidade de floração e frutificação nem sempre corresponde ao período de maior produção de flores/frutos na comunidade.

A utilização de diferentes indicadores para a avaliação do comportamento fenológico mostra que, quando consideramos apenas a porcentagem de espécies que se encontram em determinada fenofase, pode haver uma interpretação equivocada uma vez que este indicador não considera a freqüência do evento dentro da comunidade. Além disso, a escolha das espécies deve ser realizada com base na estrutura da comunidade para não se correr o risco de ter espécies com baixa densidade determinando o padrão fenológico da comunidade inteira. Outro fato a ser considerado é que mesmo a porcentagem de indivíduos não é um bom indicador, quando se pretende determinar a oferta de recursos para polinizadores e dispersores. Neste caso, análises quantitativas devem ser realizadas.

Algumas variações que ocorrem no comportamento fenológico das espécies de acordo com estratificação (sub-bosque, sub-dossel, dossel) e distribuição no mosaico florestal (clareira e borda de clareira) foram observadas. Estudos mais aprofundados levando em conta este tipo de variação devem ser realizados, principalmente em florestas estacionais semideciduais.

Observou-se, também, que há uma variação muito grande dentro das populações, com relação a presença ou ausência das fenofases em seus indivíduos. Este fato deve estar relacionado com a maturação fisiológica de cada indivíduo, avaliada neste trabalho através do diâmetro e, mesmo neste caso, com fatores abióticos (luz, temperatura, umidade, disponibilidade de nutrientes) e bióticos (competição e interdependência) a que estão submetidos.

Existe uma assincronia dos períodos de maior floração e frutificação entre árvores, arbustos e lianas para a comunidade como um todo. Esta assincronia pode variar 
de acordo com a fase de desenvolvimento do mosaico florestal. O comportamento fenológico da comunidade pode variar de acordo com as fases de desenvolvimento do mosaico florestal.

A influência das lianas no padrão de floração e frutificação foi maior na comunidade referente às áreas em fase de clareira e construção. Nas áreas em fase madura o padrão de floração foi determinado pelas espécies arbustivas, ou melhor, de sub-dossel. O padrão de frutificação foi determinado por árvores e arbustos.

Os resultados obtidos neste trabalho reforçam a importância das lianas na manutenção de recursos para polinizadores e dispersores em períodos críticos, já mencionada em outros trabalhos. Além disso, evidencia a contribuição dos arbustos na oferta de recursos para a fauna, principalmente nas áreas maduras, onde ocorrem com maior freqüência.

Estudos fenológicos abordando as variações que ocorrem de acordo com o tipo de amostragem realizada devem ser incrementados, a fim de que se possa definir uma metodologia específica para cada nível de abordagem (indivíduo, população e comunidade). Estudos futuros de comunidades devem incluir outras formas de vida além de árvores, ressaltando o papel destas na manutenção das populações de polinizadores e dispersores.

O conhecimento das variações que podem ocorrer de acordo com o estágio sucessional da floresta ou ainda nas diferentes fases de desenvolvimento do mosaico florestal deve ser aprofundado, pois trata-se de um importante fator a ser considerado nas práticas de conservação e manejo de florestas tropicais, onde muitas vezes a estrutura da comunidade é alterada. 


\section{ANEXOS}


Anexo 1 - Resultado das análises química e física das amostras de solo coletadas no interior da Mata da Bica, Botucatu - SP e analisadas no Laboratório de Fertilidade do Solo do Departamento de Ciências do Solo da UNESP/Campus de Botucatu, conforme metodologia adotada pelo IAC (Raij, 1983).

\section{ANÁLISE QÚMICA}

\begin{tabular}{|c|c|c|c|c|c|c|c|c|c|c|}
\hline 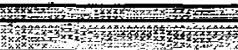 & 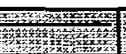 & $\mathrm{pin}$ & Mog & Pa & miin & quival & telTo & inde & Fa & 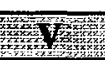 \\
\hline Profinditiale: & Pontos & $\mathrm{Cog}_{2}$ & $(6)$ & $96 / \mathrm{cm}^{2}$ & and & 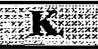 & Wy & SB & (ctc & $(6)$ \\
\hline $0-5 \mathrm{~cm}$ & 1 & 6,30 & 7,60 & 95,00 & 0,39 & 19,00 & 2,00 & 21,40 & 23,40 & 91,00 \\
\hline $0-5 \mathrm{~cm}$ & 2 & 6,30 & 6,00 & 36,00 & 0,41 & 15,00 & 2,20 & 17,60 & 19,50 & 90,00 \\
\hline $0-5 \mathrm{~cm}$ & 3 & 6,10 & 6,60 & 29,00 & 0,31 & 15,00 & 3,20 & 18,50 & 20,90 & 89,00 \\
\hline $0-5 \mathrm{~cm}$ & 4 & 6,70 & 8,60 & 61,00 & 0,33 & 20,00 & 2,50 & 22,90 & 24,30 & 94,00 \\
\hline $0-5 \mathrm{~cm}$ & 5 & 6,50 & 7,30 & 51,00 & 0,34 & 19,00 & 2,70 & 22,00 & 23,70 & 93,00 \\
\hline $0-5 \mathrm{~cm}$ & 6 & 6,00 & 6,60 & 29,00 & 0,24 & 13,00 & 2,30 & 15,60 & 17,80 & 87,00 \\
\hline $0-5 \mathrm{~cm}$ & 7 & 6,60 & 6,30 & 58,00 & 0,55 & 17,00 & 2,90 & 20,40 & 21,90 & 93,00 \\
\hline $10-25 \mathrm{~cm}$ & 1 & 5,50 & 2,70 & 12,00 & 0,07 & 7,40 & 1,60 & 9,10 & 11,90 & 77,00 \\
\hline $10-25 \mathrm{~cm}$ & $\overline{2}$ & 4,40 & 2,50 & $\overline{7,00}$ & 0,10 & 2,90 & 1,00 & 4,00 & 9,20 & 43,00 \\
\hline $10-25 \mathrm{~cm}$ & 3 & 5,30 & 3,60 & 8,00 & 0,08 & 7,00 & 3,10 & 10,10 & 13,10 & 78,00 \\
\hline $10-25 \mathrm{~cm}$ & 4 & 5,70 & 3,20 & 11,00 & 0,19 & 7,10 & 1,80 & 9,10 & 11,50 & 79,00 \\
\hline $10-25 \mathrm{~cm}$ & 5 & 5,90 & 2,70 & 14,00 & 0,21 & 7,60 & 2,30 & 10,20 & 12,30 & 83,00 \\
\hline $10-25 \mathrm{~cm}$ & 6 & 5,80 & 2,90 & 41,00 & 0,07 & 7,50 & 1,50 & 9,00 & 11,30 & 80,00 \\
\hline $10-25 \mathrm{~cm}$ & 7 & 5,70 & 3,20 & 15,00 & $\overline{0,50}$ & 6,70 & 2,30 & 9,50 & 12,00 & 79,00 \\
\hline $25-60 \mathrm{~cm}$ & 1 & 4,80 & 1,80 & 6,00 & 0,03 & 3,70 & 0,90 & 4,70 & 8,10 & 58,00 \\
\hline $25-60 \mathrm{~cm}$ & 2 & 4,40 & 1,50 & 6,00 & 0,09 & 2,80 & 0,90 & 3,80 & 8,00 & 47,00 \\
\hline $25-60 \mathrm{~cm}$ & 3 & 4,50 & 1,50 & 4,00 & 0,08 & 2,80 & 1,60 & 4,50 & 8,10 & 55,00 \\
\hline $25-60 \mathrm{~cm}$ & 4 & 5,50 & 2,30 & 9,00 & 0,17 & 6,20 & 1,70 & 8,10 & 10,50 & 77,00 \\
\hline $25-60 \mathrm{~cm}$ & 5 & 5,60 & 1,90 & 8,00 & 0,19 & 6,00 & 2,20 & 8,30 & 10,70 & 78,00 \\
\hline $25-60 \mathrm{~cm}$ & 6 & 5,60 & 1,40 & 7,00 & 0,06 & 4,00 & 1,40 & 5,40 & 7,70 & 71,00 \\
\hline $25-60 \mathrm{~cm}$ & 7 & 4,80 & 1,50 & 5,00 & 0,18 & 3,20 & 1,50 & 4,90 & 8,30 & 59,00 \\
\hline
\end{tabular}

ANÁLISE FÍSICA

\begin{tabular}{|c|c|c|c|c|}
\hline W & 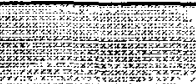 & 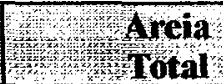 & $\begin{array}{l}\text { Argila } \\
0 \mathbf{c 0 0 2 \mathrm { mm }} \\
\text {, }\end{array}$ & $\begin{array}{c}\text { Silte } \\
, 05 f, 002 \mathrm{~mm}\end{array}$ \\
\hline Profundidade & Pontos & कि & $(\%)$ & $(\%)$ \\
\hline $10-25 \mathrm{~cm}$ & 1 & 5,50 & 2,70 & 12,00 \\
\hline $10-25 \mathrm{~cm}$ & 2 & 4,40 & 2,50 & 7,00 \\
\hline $10-25 \mathrm{~cm}$ & 3 & 5,30 & 3,60 & 8,00 \\
\hline $10-25 \mathrm{~cm}$ & 4 & 5,70 & 3,20 & 11,00 \\
\hline $10-25 \mathrm{~cm}$ & 5 & 5,90 & 2,70 & 14,00 \\
\hline $10-25 \mathrm{~cm}$ & 6 & 5,80 & 2,90 & 41,00 \\
\hline $10-25 \mathrm{~cm}$ & 7 & 5,70 & 3,20 & 15,00 \\
\hline $25-60 \mathrm{~cm}$ & 1 & 4,80 & 1,80 & 6,00 \\
\hline $25-60 \mathrm{~cm}$ & 2 & 4,40 & 1,50 & 6,00 \\
\hline $25-60 \mathrm{~cm}$ & 3 & 4,50 & 1,50 & 4,00 \\
\hline $25-60 \mathrm{~cm}$ & 4 & 5,50 & 2,30 & 9,00 \\
\hline $25-60 \mathrm{~cm}$ & 5 & 5,60 & 1,90 & 8,00 \\
\hline $25-60 \mathrm{~cm}$ & 6 & 5,60 & 1,40 & 7,00 \\
\hline $25-60 \mathrm{~cm}$ & 7 & 4,80 & 1,50 & 5,00 \\
\hline
\end{tabular}




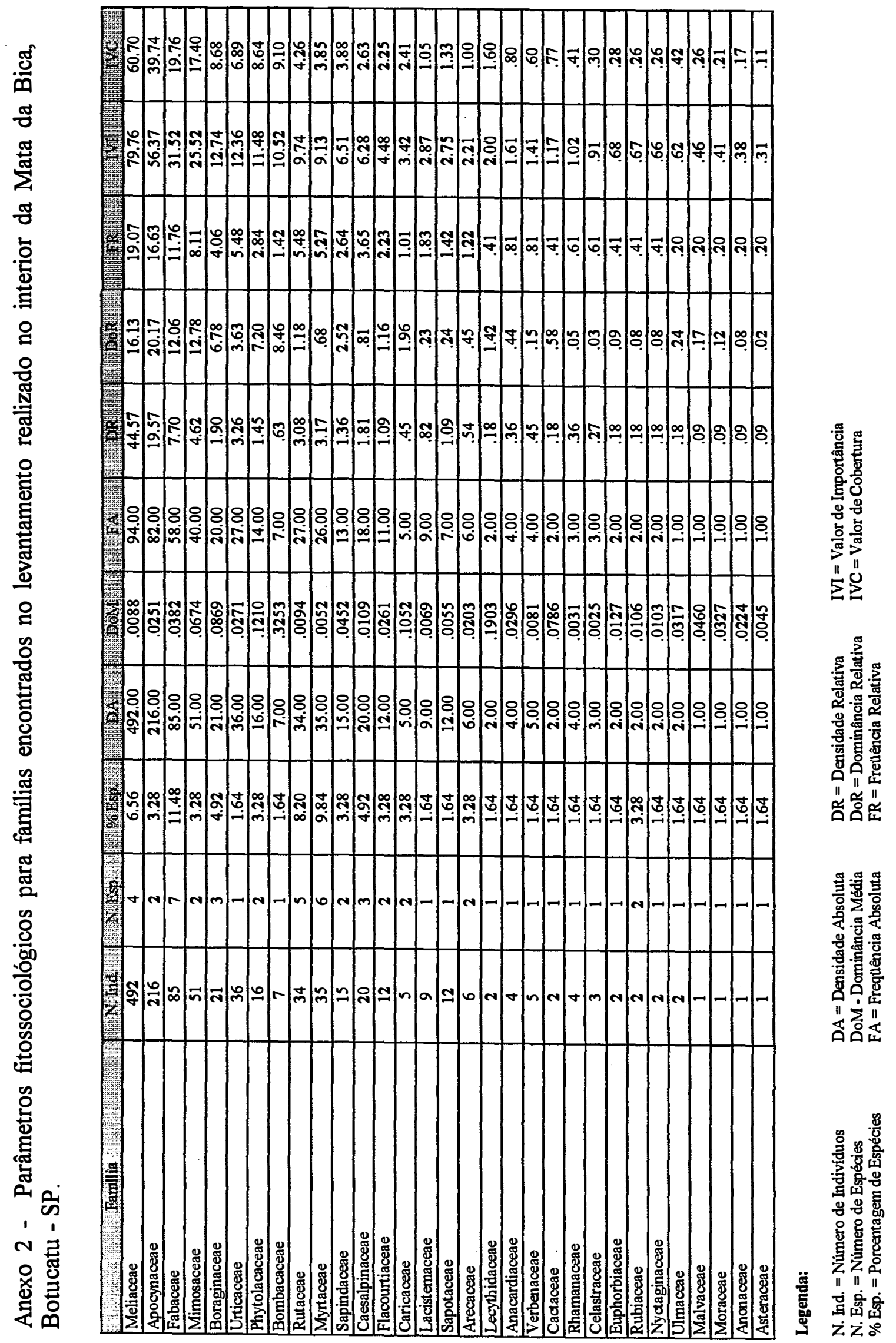




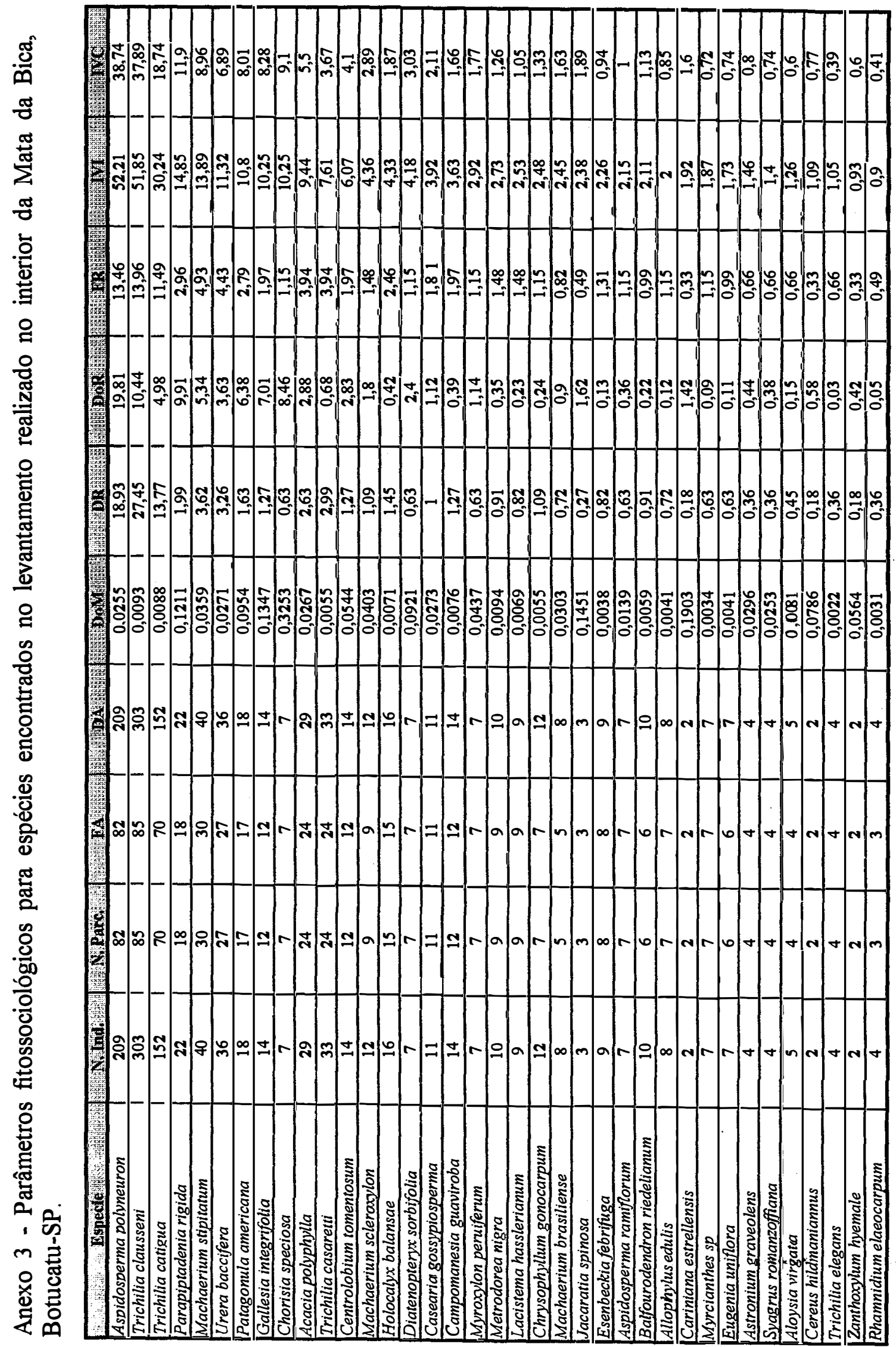




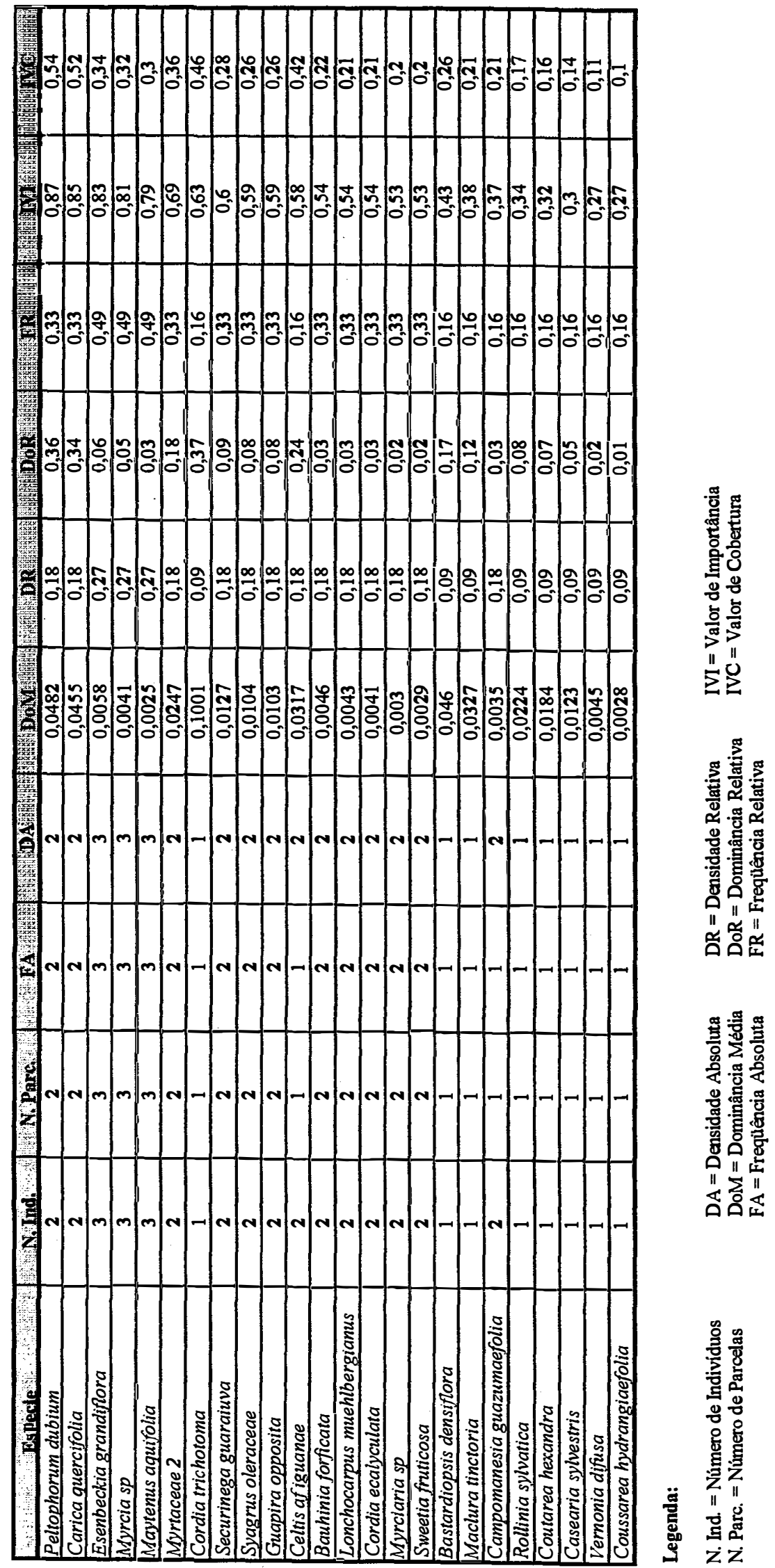




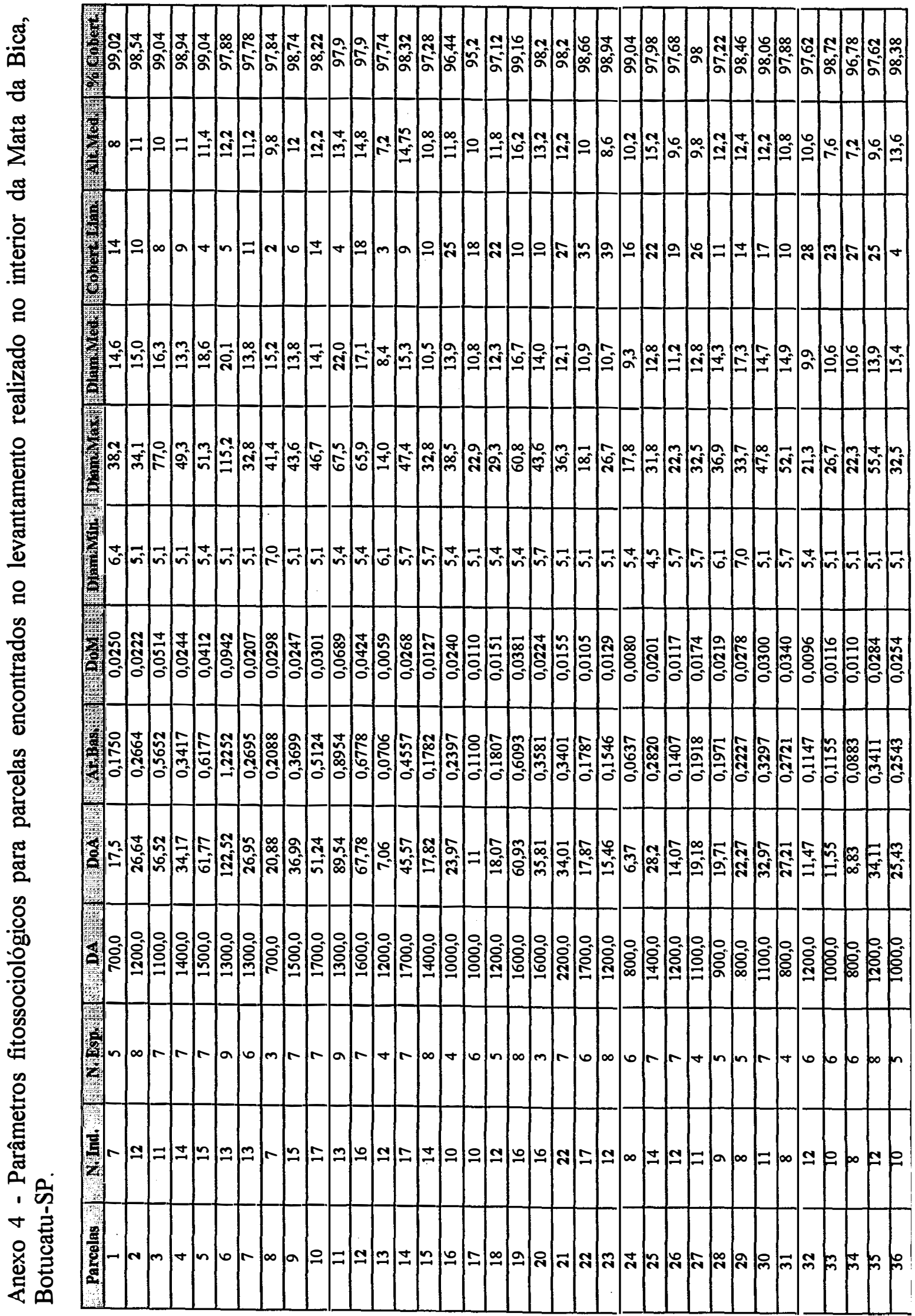




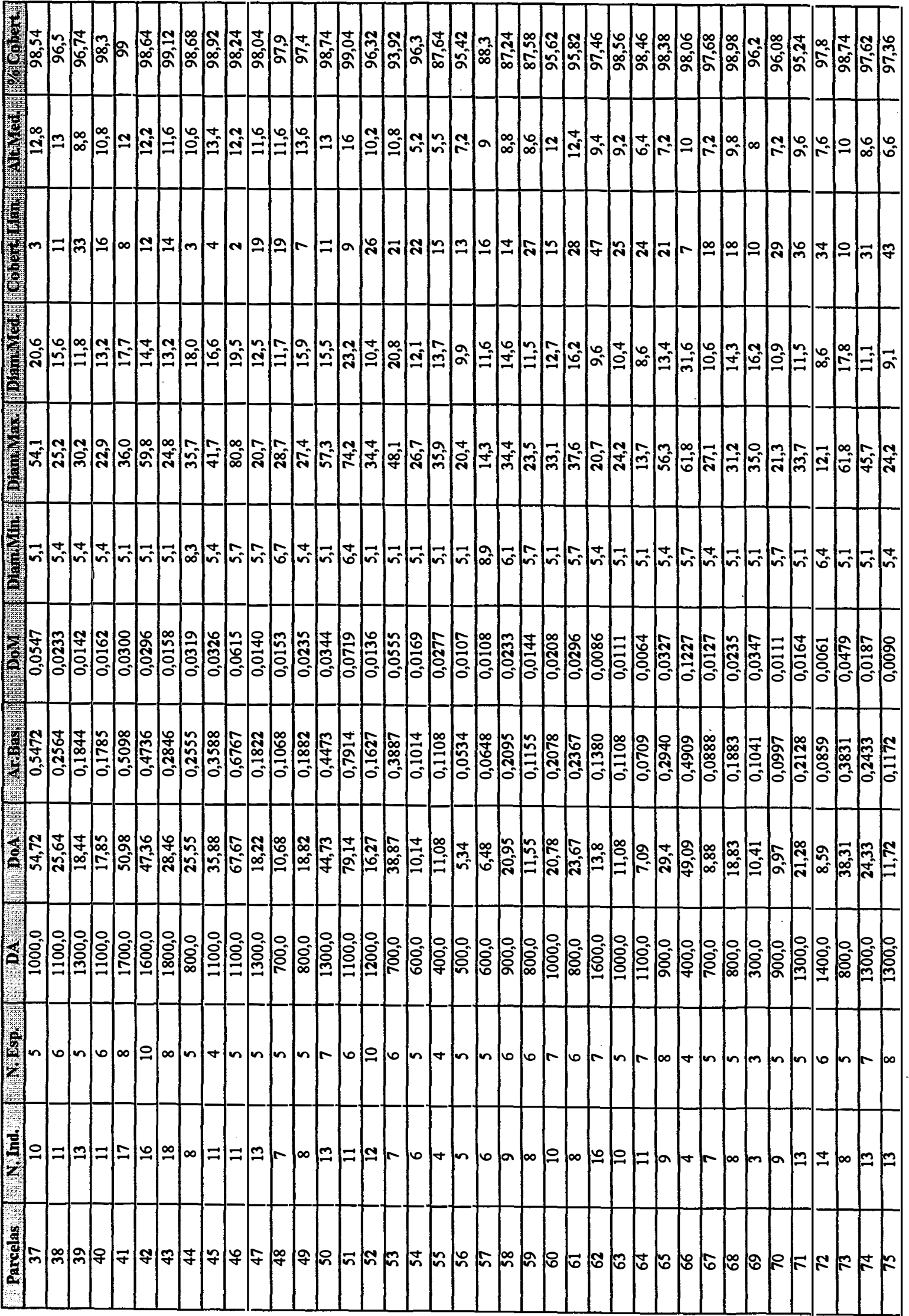




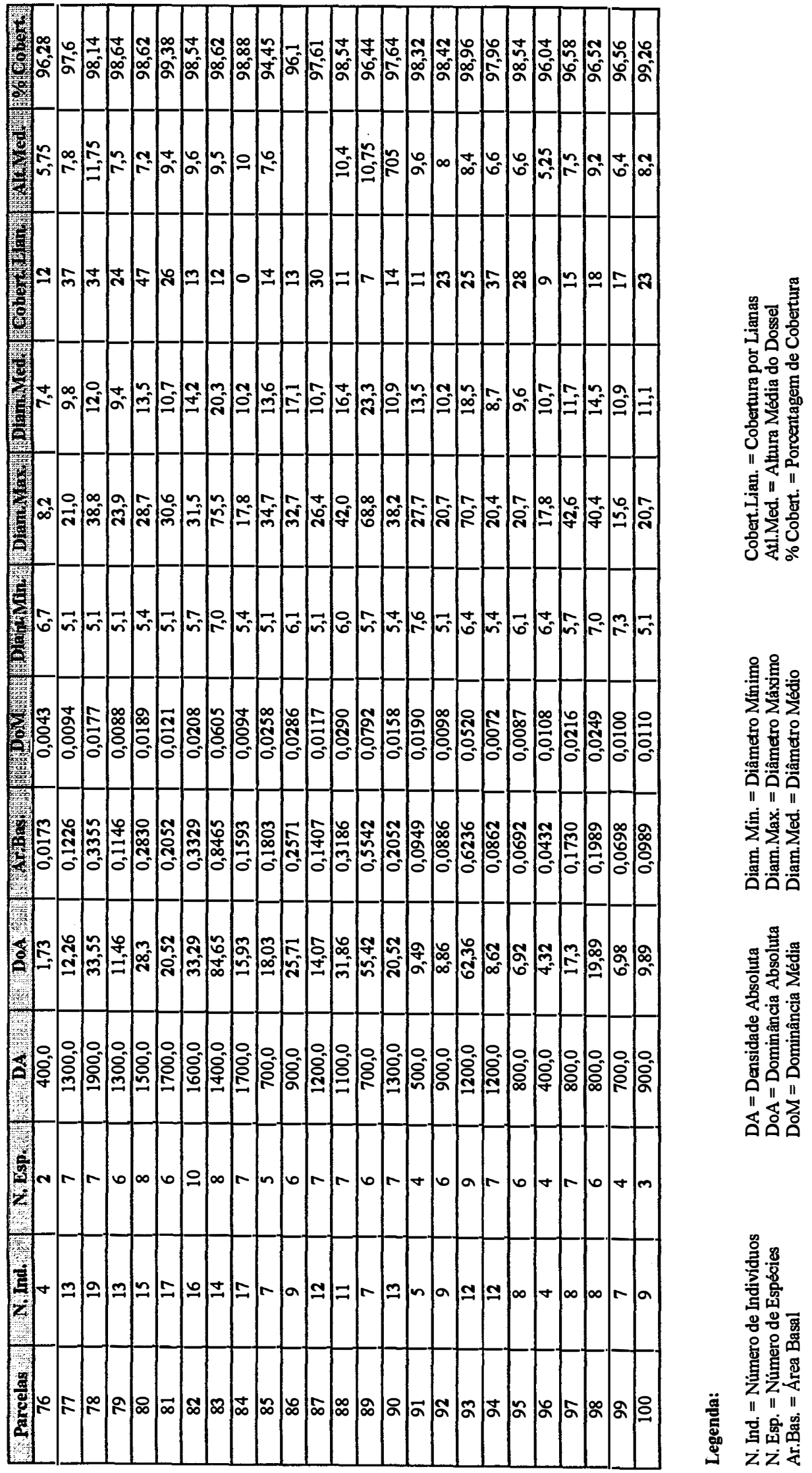




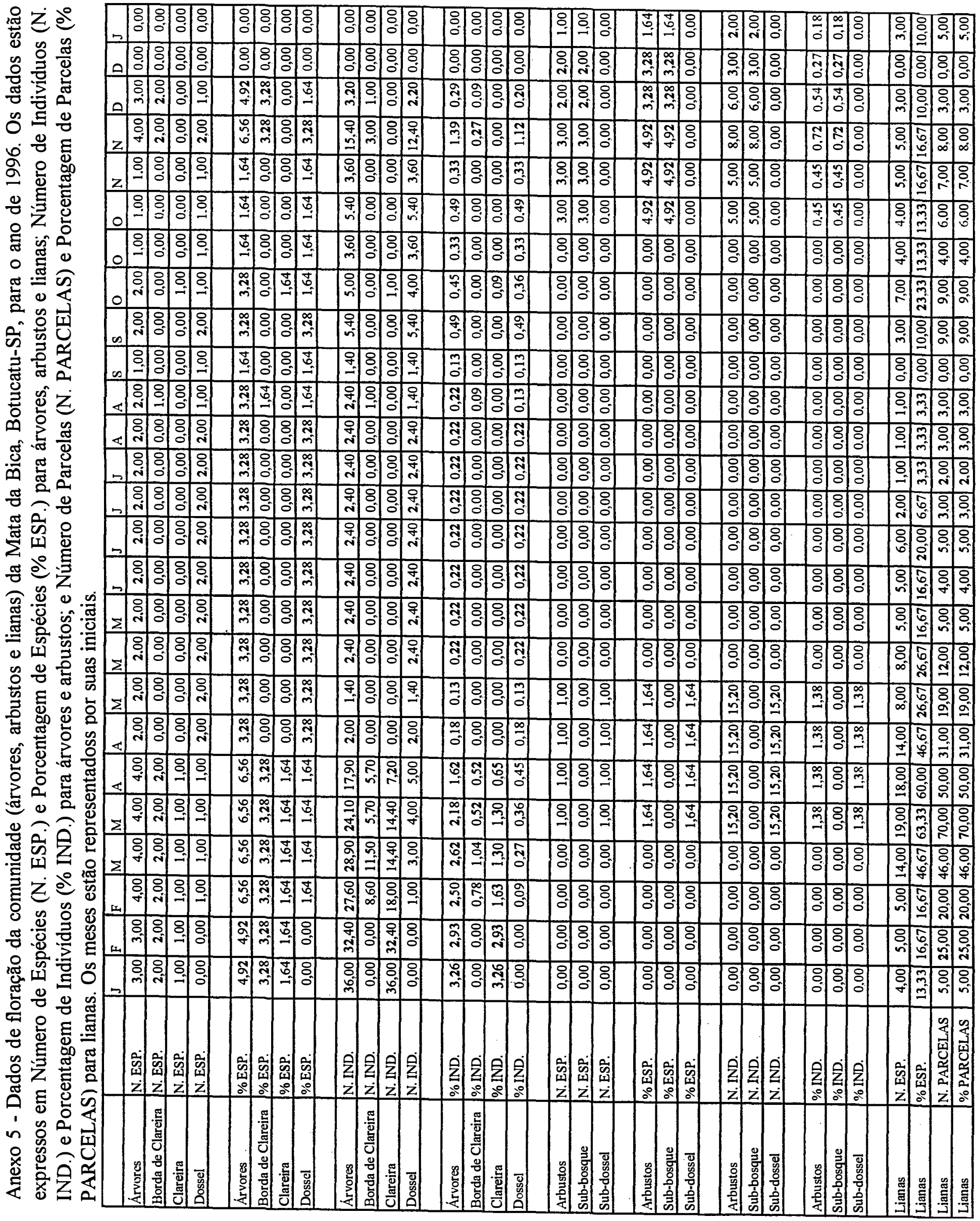




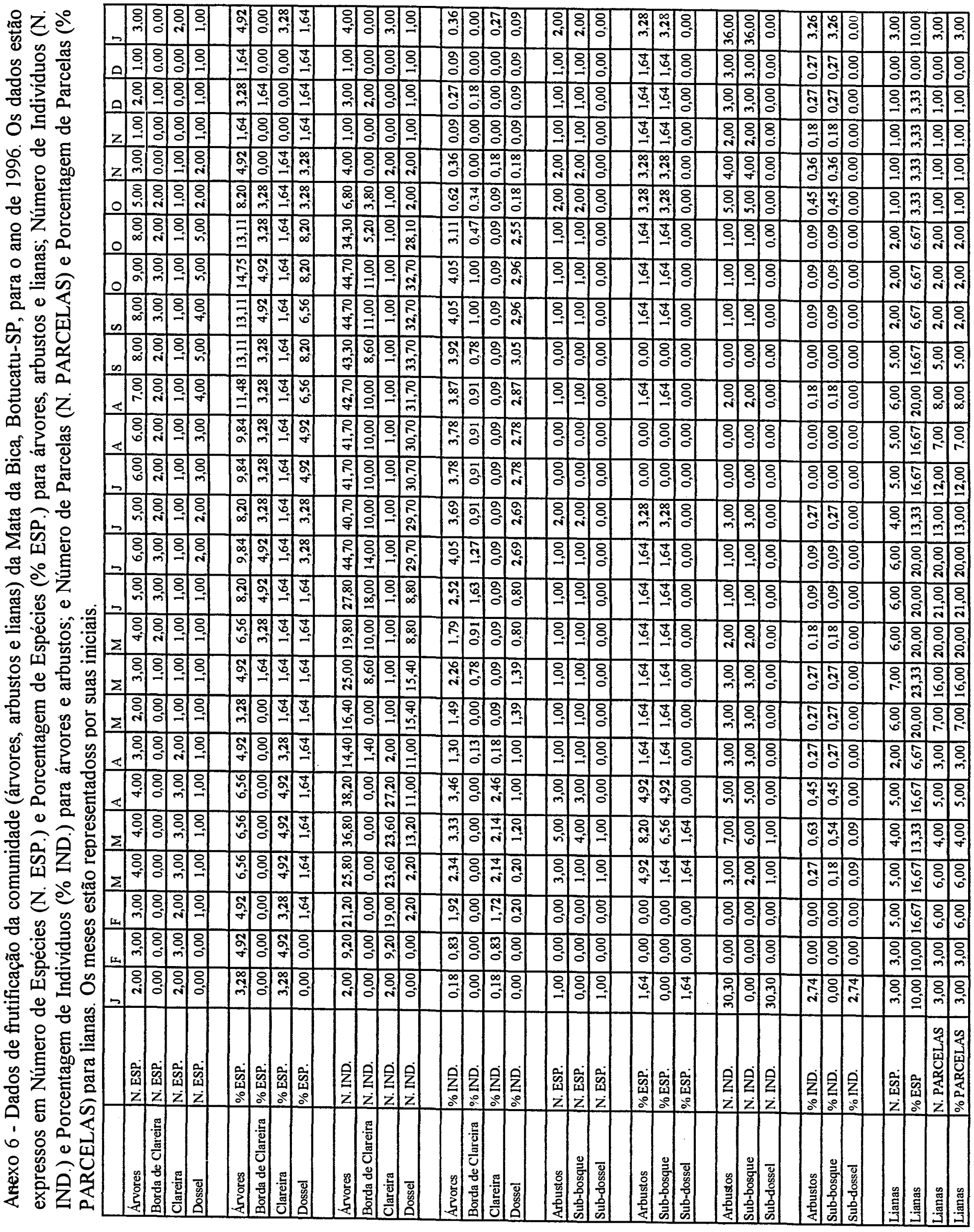




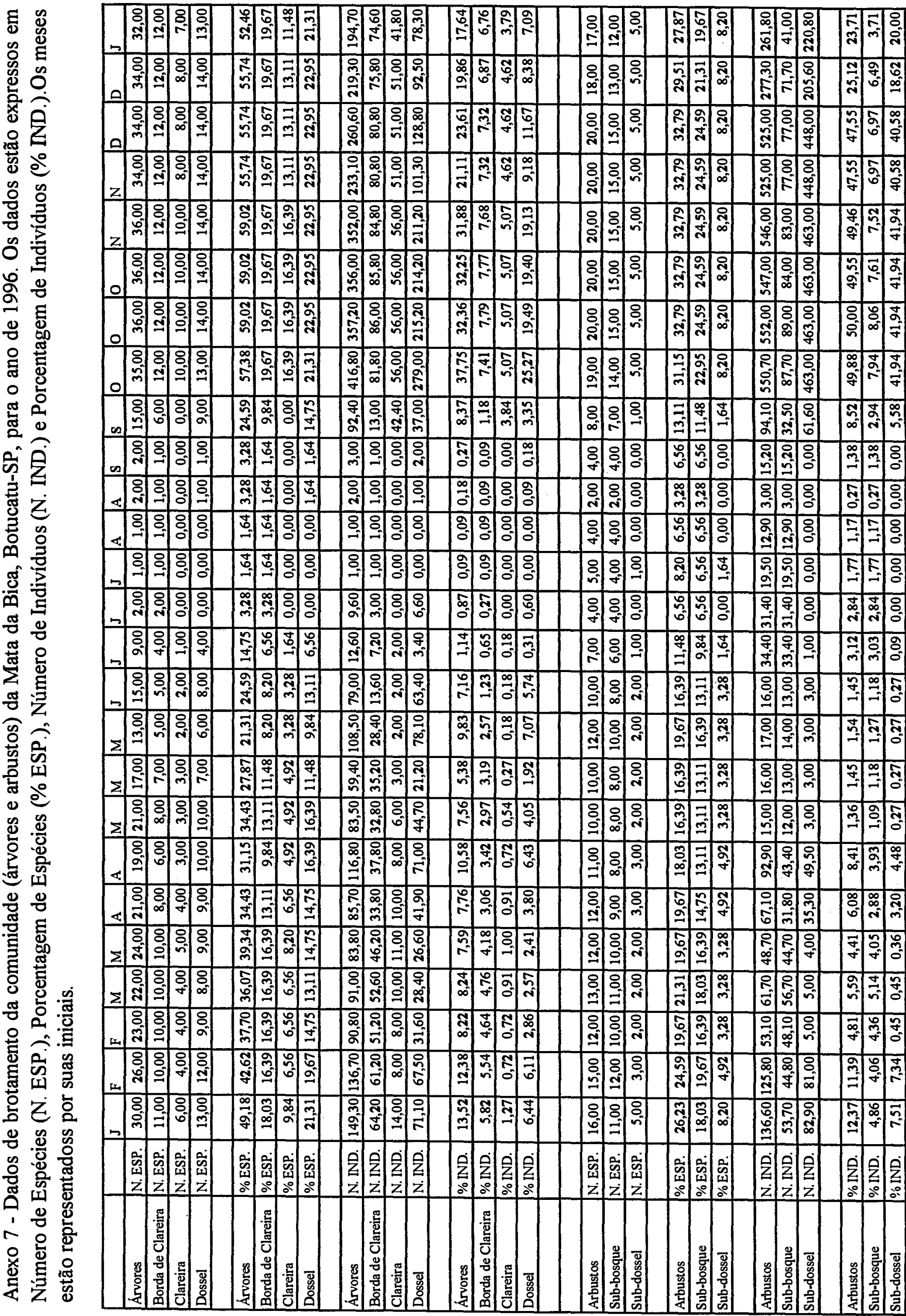




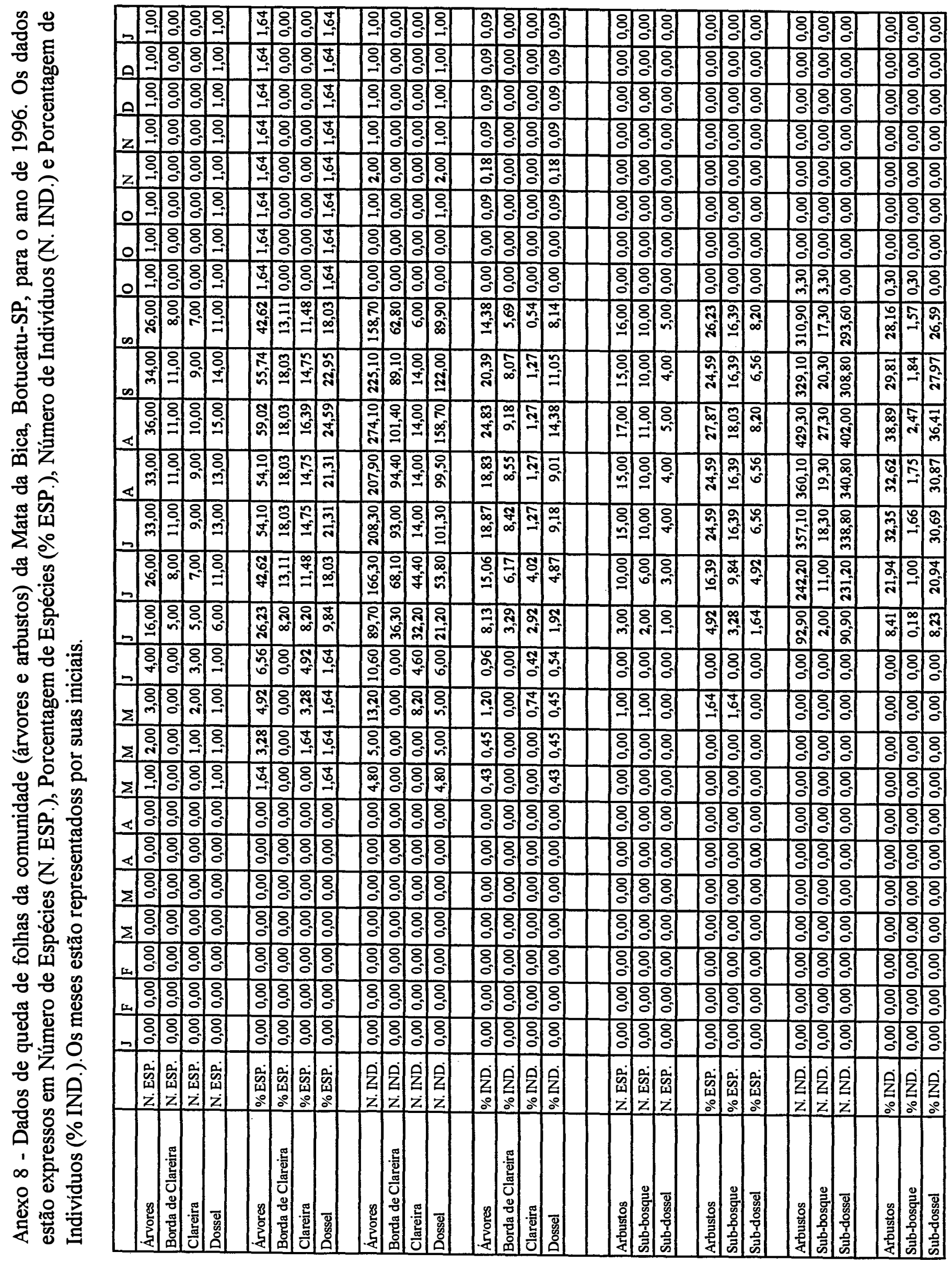




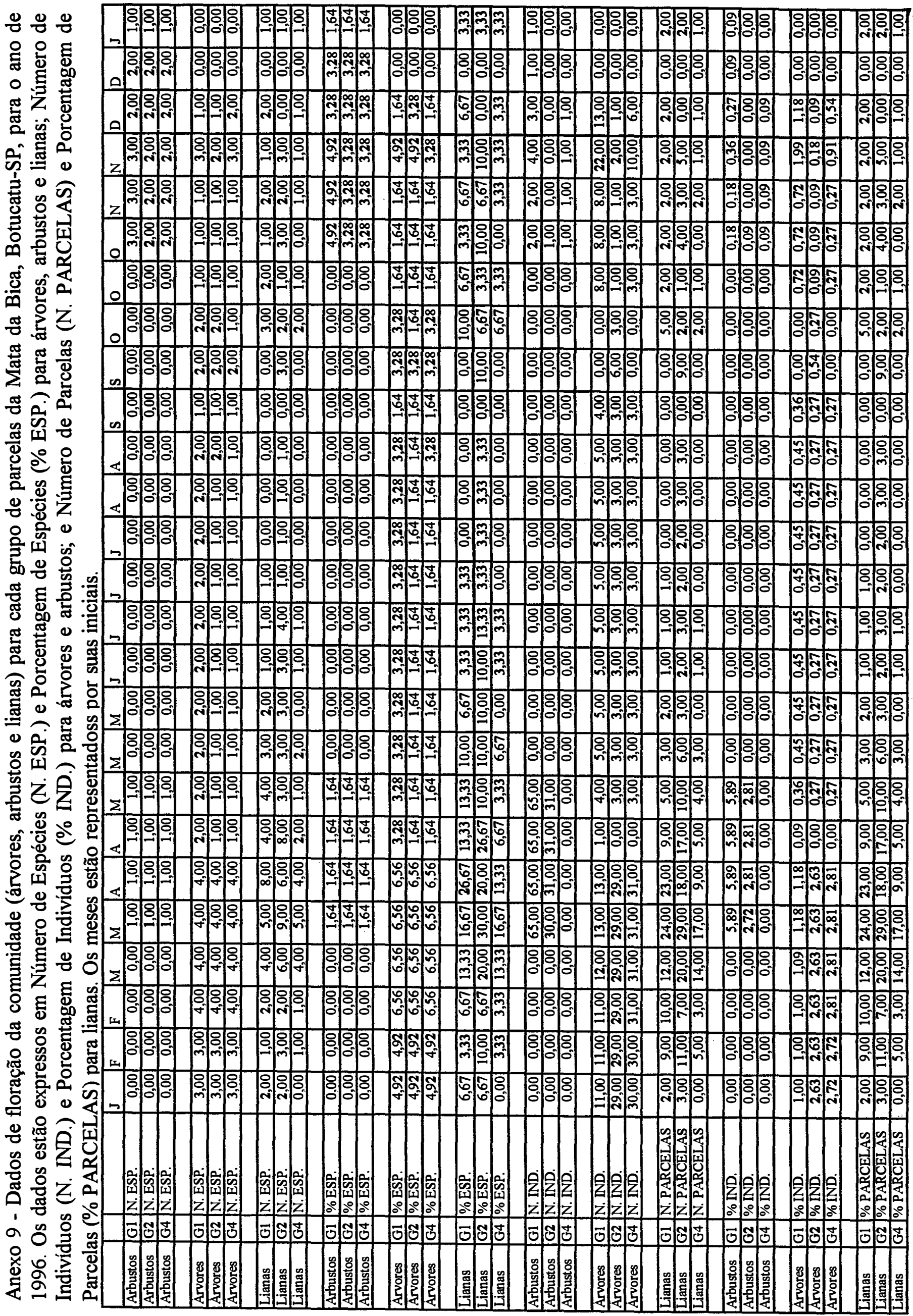




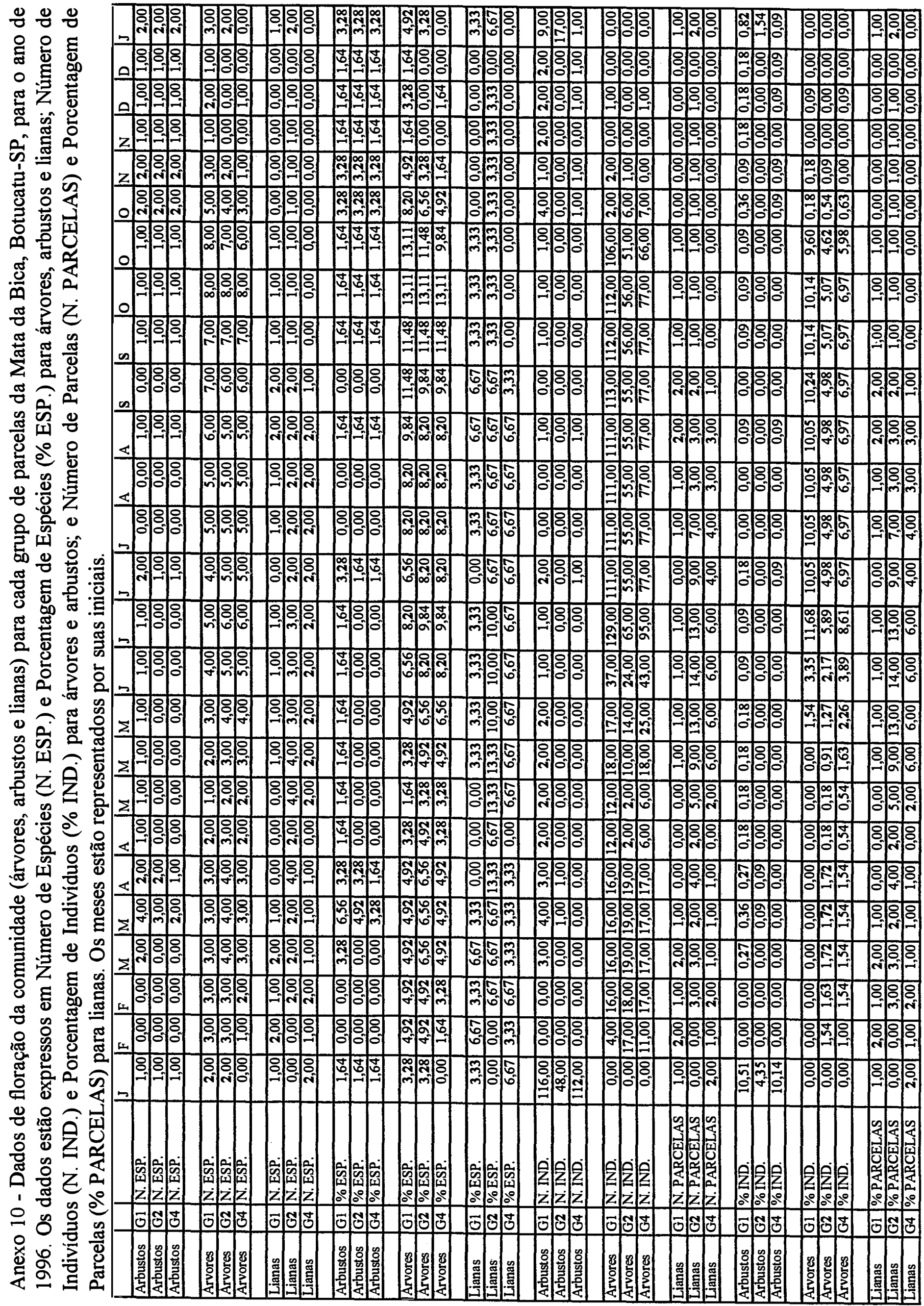




\section{REFERÊNCIAS BIBLIOGRÁFICAS}

ALENCAR, J.C.; ALMEIDA, R.A. \& FERNANDES, N.P. Fenologia de espécies florestais em floresta tropical úmida de terra firme na Amazônia Central. Acta Amazônica, v. 9, n.1, p.163-198, 1979.

AMARAL, W.A.N. Ecologia Reprodutiva de Citharecylum myrianthum Cham. (Verbenaceae) em mata ciliar do município de Botucatu - SP. Piracicaba, 1993. 221p. Dissertação (Mestrado) - Escola Superior de Agricultura "Luiz de Queiroz", Universidade de São Paulo.

ARAÚJO, V.C. Fenologia de essências florestais amazônicas. Boletim do Instituto de Pesquisa da Amazônia, v. 4, p. 1-25, 1970.

BAWA, K.S. \& KRUGMAN, S.L. Reproductive biology and genetics of tropical trees in relation to conservation and management. In: GOMEZ-POMPA, A.; WHITMORE, T.C. \& HADLEY, M. Rain forest regeneration and management. Paris: Pathernon Publ., 1993. cap.5, p. 119-136.

BERNACCI, L.C. \& LEITÃO FILHO. Flora fanerogâmica da floresta da Fazenda São Vicente, Campinas, SP. Revista Brasileira de Botânica, v.19, n.2, p149-164, 1996.

BUDOWSKI, G. Distribution of tropical American rain forest species in the light of secessional processes. Turrialba, v.15, p.40-42, 1965.

BORCHERT, R. Soil and stem water storage determine phenology and distribuition of tropical dry forest trees. Ecology, v.75, n.5, p.1437-1449, 1994. 
BULLOCK, S.H. \& SÓLIS-MAGALLANES, A. Phenology of canopy trees of tropical deciduous forest in México. Biotropica, v.22, n.1, p.22-35, 1990.

CARABIAS-LILLO, J. \& SADA, S.G. Fenologia en una selva tropical humeda y en una comunidad derivada; Los Tuxtlas, Veracruz. In: GOMEZ-POMA, A. (Ed.) Investigation on the regeneration of high forest in Veracruz, Mexico. México: Editorial Alhambra Mexicana, 1985. v.2, p.27-66.

CARDOSO-LEITE, E. Ecologia de um fragmento florestal em São Roque, SP: florística, fitossociologia e silvigênese. Capinas, 1995 . 198p. Dissertação (Mestrado) - Universidade Estadual de Campinas - UNICAMP.

CARVALHO, W.; PANOSO, L.A. \& MORAES, M.H. de Levantamento semidetalhado dos solos da Fazenda Experimental Edgardia, Município de Botucatu SP. FEPAF, v.1-2, 1991. 467p. Boletim Científico, 2.

CROAT, T.B. Phenological behavior of habit and habitat classes on Barro Colorado Island (Panama Canal Zone). Biotropica, v.7. p. 270-277, 1975.

CRONQUIST, A. The evolution and classification of flowering plants. New York: The New Work Botanical Garden, 1988.

DENSLOW, J.S. Tropical rain forest gaps and tree species diversity. Annual Review of Ecology an Systematics, v.18, p.431-451, 1987.

DUBOIS, S.L. Característica e distribuição geográfica das florestas naturais de folhosas no Brasil, reflorestamentos para produção de madeira e serraria: tendências e possibilidades. Silvicultura em São Paulo, v.7, p.11-26, 1970.

DUTRA, R.C. Fenologia de dez espécies arbóreas nativas do cerrado de Brasilia - D.F. Brasil Florestal, v.14, n.62, p.23-41, 1987. 
ENGEL, V.L. \& PRADO, P.I.K.L. Aspectos da silvigênese de uma mata pluvial atlântica em Linhares,ES. In: CONGRESSO NACIONAL SOBRE ESSÊNCIAS NATIVAS, 2. Anais. São Paulo: Revista do Instituto Florestal, 1992. v. 4, p.163168 (Edição Especial, Pt3).

FOURNIER, L.A. Observaciones fenológicas en el bosque humido premontano de San Pedro de Montes Oca, Costa Rica. Turrialba, v.26, p.54-59, 1976.

FOURNIER, L.A. Um método cuantitativo para la medición de características fenológicas en árboles. Turrialba, v.24, n.4, p.422-423, 1974.

FOURNIER, L.A. \& CHARPANTIER, C. Tamaño de la nuestra y la frequencia de las observaciones en el estudio de las características de los arboles tropicales. Turrialba, v. 25, n.1, 45-48, 1975.

FRANCKIE, G.W.; BAKER, H.G. \& OPLER, P.A. Comparative phenological studies of trees in tropical lowland wetland dry forest sites of Costa Rica. Journal of Ecology, v. 62, p.881-913, 1974.

FUNDAÇÃO SOS MATA ATLÂNTICA \& INSTITUTO NACIONAL DE PESQUISAS ESPACIAIS. Atlas: Evolução dos Remanescentes florestais e ecossistemas associados do domínio Mata Atlântica no período 1985-90. São Paulo: Fundação SOS Mata Atlântica, 1992. 199p.

GABRIEL, J.L.C. Composição florística e estrutura fitossociológica do estrato arbóreo de mata mesófila semidecídua de encosta, no município de Botucatu, SP. Rio Claro, 1990. 198 p. Dissertação (Mestrado) - Universidade Estadual Paulista "Júlio de Mesquita Filho".

GANDOLFI, S.; LEITÃO FILHO, H. \& BEZERRA, C.L.F. Levantamento florístico caráter sucessional das espécies arbustivo-arbóreas de uma floresta mesófila semidecídua no município de Guarulhos - SP. Revista Brasileira de Botânica, v.55, n.4, p.753-767, 1995. 
HALLÉ, F.; OLDEMAN, R.A.A. \& TOMLINSON, P.B. Tropical trees and forest. Berlin: Spriger-Verlag, 1978. 441p.

HEIDEMAN, P.D. Temporal and spatial variation in the phenology of flowering and fruiting an tropical rainforest. Journal of Ecology, v.77, p.1059-1079, 1989.

IBARRA-MANRÍNQUEZ, G.; SÁNCHEZ-GARFIAS, B. \& GONZÁLEZ-GARCIA, L. Fenologia de lianas y arboles anemocoros en una selva calido-humeda de México. Biotropica, v.23, n.3, p.242-254, 1991.

INSTITUTO BRASILEIRO DE GEOGRAFIA E ESTATÍSTICA. Classificação da vegetação brasileira, adaptada a um sistema universal. Rio de Janeiro: IBGE, 1991. $123 \mathrm{p}$.

IVANAUSKAS, N.M.; NAVE, A.G. \& RODRIGUES, R.R. Caracterização de remanescentes de florestas nativas das fazendas da Eucatex Florestal. Piracicaba: ESALQ, Departamento de Botânica, 1994. 138p. (Relatório de Atividades).

IVANAUSKAS, N.M. Caracterização florística e fisionômica da Floresta Atlântica sobre a formação Pariquera-Açu, na zona da morraria costeira do estado de São Paulo. Campinas, 1997. 217p. Dissertação (Mestrado) - Universidade Estadual de Campinas.

JACKSON, S.F. Seasonality of flowering and leaf-fall in brasilian subtropical lower montane moist forest. Biotropica, v.10, p.38-42, 1978.

JOLY, A.B. Botânica: introdução à taxonomia vegetal. São Paulo: Editora Nacional, 4 ed., 1977. 777p.

KAGEYAMA, P.Y. Conservação "in situ"de recursos genéticos de plantas. IPEF, v.35, p.7-37, 1987. 
KIM, A.C. Lianas da Mata Atlântica do estado de São Paulo. Campinas, 1996. 211p. Dissertação (Mestrado) - Universidade Estadual de Campinas.

KOPTUR, S.; HABER, W.A.; FRANKIE, G.W \& BAKER, H.G. Phenological studies of scrubs and treelet species in tropical cloud forest of Costa Rica. Jounal of Tropical Ecology, v.4, p.347-359, 1988.

KOTCHETKOFF-HENRIQUES, O. \& JOLY, C.A. Estudo florístico e fitossociológico em uma mata mesófila semidecídua da serra do Itaqueri, Itirapina, Estado de São Paulo, Brasil. Revista Brasileira de Biologia, p. 477-487, 1994

LEITÃO FILHO, H.F. Considerações sobre a florística de florestas tropicais e subtropicais do Brasil. IPEF, v. 35, p.41-46, 1987.

LIETH, H. Introducion to phenology and modeling of seasonality. In: LIETH, H. (Ed.). Phenology and seasonality modeling. Berlin: Springler-Verlag, 1974. p.319.

LIMA JÚNIOR, M.J.V. \& ALENCAR, J.C. Fenologia de duas espécies do gênero Corythophora da familia Lecythidaceae na Reserva Florestal Ducke, Manaus - A.M. In: CONGRESSO NACIONAL SOBRE ESSÊNCIAS NATIVAS, 2. Anais. São Paulo: Revista do Instituto Florestal, 1992. v. 2, p.23-40 (Edição Especial, Pt3).

MANTOVANI, W.; ROSSI, L.; ROMANUIC, S. et al. Estudo fitossociológico de áreas de mata ciliar em Mogi-Guaçu, SP, Brasil. In: SIMPÓSIO BRASILEIRO SOḂRE MATA CILIAR, São Paulo, SP, 1989. Anais. Campinas: Fundação Cargill, 1989. p.235-267.

MARTINEZ-RAMOS, M. Claros, ciclos vitales de los arboles tropicales y regeneration natural de las selvas altas perennifolias. In: GOMEZ-POMPA, A. \& AMO, S.R. del (Ed.). Investigaciones sobre la regeneration natural de las selvas altas en Veracruz, México. México: Editorial Alhambra Mexicana, 1985. v.2, p.191-239. 
MATTHES, L.A. Composição florística, estrutura e fenologia de uma floresta residual do planalto paulista: Bosque dos Jequitibás (Campinas-SP). Campinas, 1980. Dissertação (Mestrado) - Universidade Estadual de Campinas.

MORELLATO, L.P.C. Estudo da fenologia de árvores, arbustos e liana de uma floresta semidecídua no Sudeste do Brasil. Campinas, 1991. 176p. Tese (Doutorado) Universidade Estadual de Campinas.

MORELLATO, L.P.C. \& LEITÃO FILHO, H.L. Estratégias fenológicas de espécies arbóreas em floresta mesófila na Serra do Japi, Jundiaí, SP. Revista Brasileira de Biologia, v.50, p.163-173, 1990.

MORELLATO, L.P.C.; RODRIGUES, R.R.; LEITÃO FILHO, H.F. \& JOLY, C.A. Estudo Comparativo da fenologia de espécies arbóreas de floresta de altitude e floresta mesófila semidecídua na Serra do Japi, Jundiaí, São Paulo. Revista Brasileira de Botânica, v.12, p.85-9, 1989.

MORELLATO, P.C. \& LEITÃO-FILHO. H.F. Reproductive phenology of climbers in southeastern Brazilian forest. Biotropica, v.28, n.2, p.180-191, 1996.

NEWSTROM, L.E.; FRANCKIE, G.W.; BAKER, H.G. \& COLWELL, R.K. Diversity of flowering patterns at La Selva. In: BAWA, K.S.; McDADE, L.A.; HATSHORN, G.S. \& HESPEHNEID, H.A. (Ed.). La Selva: ecology and natural history of a lowland tropical rain forest. Chicago: Univ. of Chicago Pres, 1993.

OLDEMAN, R.A.A. Dynamics in tropical rainforests. In: HOLM-NIELSEN, L.B.; NIELSEN, I.C. \& BALSLAV, H. Tropical forest: botanical dynamics, speciation and diversity. Academic Press, 1989. p.3-21.

OLDEMAN, R.A.A. Elements of silvology. New York: Spriger-Verlag, 1990. 623p. 
OLDEMAN, R.A.A. Tropical rainforest, architecture, sylvigenesis and dyversity. In: SUTTON, S.L.; WHITMORE, T.C.; CHADWICK, A.C. (Ed.). Tropical rainforest: ecology and management. Oxford: Blackwell Scientific, 1983. p.139150.

OLIVEIRA, R.E. Aspectos da dinâmica de um fragmento florestal em Piracicaba-SP: silvigênese e ciclagem de nutrientes. Piracicaba, 1997. 79p. Dissertação (Mestrado) - Escola Superior de Agricultura "Luiz de Queiroz", Universidade de São Paulo.

OPLER, P.A.; BAKER, H.G. \& FRANCKIE, G.W. Seasonality of climber communities: a review and example from Costa Rica dry forest. In: PUTZ, F.E.; MOONY \& BULLOIR (Ed.). Biology of vines. Cambridge: Cambridge University Press, 1991.

OPLER, P.A.; FRANCKIE, G.W. \& BAKER, H.G. Comparative phenological studies of treelet and schrub species in tropical wet and dry forest in the lowlands of Costa Rica. Journal of Ecology, v.68(1), p.167-188, 1980.

OPLER, P.A.; FRANCKIE, G.W. \& BAKER, H.G. Rainfall as a factor in the release, timing and synchronization of anthesis by tropical trees and shrubs. Journal of Biogeography, v.3, p.231-236, 1976.

ORTEGA,V.R. \& ENGEL, V.L. Conservação da biodiversidade de remanescentes de Mata Atlântica na região de Botucatu, SP. In: CONGRESSO NACIONAL SOBRE ESSÊNCIAS NATIVAS, 2. Anais. São Paulo: Revista do Instituto Florestal, 1992. v.4, p.839-852 (Edição Especial, Pt3).

PUTZ, F.E. \& WINDSOR, D.M. Liana phenology on Barro Colorado Island, Panama. Biotropica, v.19, p.334-341, 1987.

RAIJ, B.V. Métodos de análises de solo para fins de fertilidade. IAC, n.81, 1983. 31 . Boletim Técnico. 
RAMALHO, R. S. \& MARANGON, L.C. Características fenológicas de Melanoxylon brauna Schott., em Viçosa - Minas Gerais. Revista Árvore, v.13, n.2, p.303-309, 1989.

RAMOS NETO, M.N. Análise florística e estrutural de duas florestas sobre a restinga, Iguape, São Paulo. São Paulo, 1993. 129p. Dissertação ( Mestrado) Universidade de São Paulo.

REICH, P.B. Phenology of tropical forests: patterns, causes, and consequences. Canadian Journal of Botany, v.73, n.2, p.164-174, 1995.

RIZZINI, C.T. Tratado de fitogeografia do Brasil: aspectos florísticos e estruturais. São Paulo: HUCITEC/EDUSP, v.2, 1979. 374p.

RODRIGUES, R.R. Métodos Fitossociológicos mais usados. Campinas: Casa da Agricultura, v.10, n.1, 1988. 5p.

RODRIGUES, R.R., TAMASHIRO, J. Y.; SHEPHERD, G.J. \& SANTOS, F.A.M. dos. Levantamento fitossociológico de um trecho de mata mesófila semidecídua, Santa Genebra, Campinas, SP. Revista Brasileira de Botânica. /No prelo/

ROZZA. A.F. Florística, fitossociologia e caracterização sucessional da Mata da Virgínia, Município de Matão - SP. In: XLVII CONGRESSO NACIONAL DE BOTÂNICA, Nova Friburgo, 1996. Anais. Nova Friburgo.

SARMIENTO, G. \& MONASTERIO, M. Life forms and phenology. In: Tropical savannas (F. Bourlière, ed.). Amsterdan: Elsevier Scientific Publishing Company, 1983.

SETZER, J. Atlas climático e ecológico do Estado de São Paulo. São Paulo: Comissão Interestadual da Bacia Paraná-Uruguai e Centrais Elétricas do Estado de São Paulo, 1966. 61p. 
SHEPHERD, G.J. Fitopac 1 - Manual do Usuário. Campinas: UNICAMP, Departamento de Botânica, 1995.

SILVA FILHO, S.R. \& ENGEL, V.L. Estrutura de um fragmento de mata mesófila semidecídua secundária tardia e implicações para o manejo. In: CONGRESSO FLORESTAL BRASILEIRO, 7, Curitiba, 1993. Anais. Paraná: SBS-SBEF, 1993. v.1, p.343-346.

SPINA, A.P. Composição florística de uma floresta de brejo na região de Campinas, e algumas considerações sobre os sistemas sexuais, fenologia de floração e frutificação e as síndromes de dispersão das espécies da comunidade. Campinas, 1997. 169p. Dissertação (Mestrado) - Universidade Estadual de Campinas.

STATSOFT. Programa: STATISTCA for Windows (software). Versão 4.3 B, 1993.

THORNTHWAITE. C.W. \& MATHER, J.R. The balance water. New Jersey: Laboratory of Climatology, v.8, n.1, 1955. 104p.

VIANA, V.M. Biologia e manejo de fragmentação de florestas naturais. In: CONGRESSO FLORESTAL BRASILEIRO, 6, Campos de Jordão, 1990. Anais. São Paulo: SPS-SBEF, 1990. v.1, p.113-118.

VIANA, V.M. et al. Restauração e manejo de fragmentos florestais. In: CONGRESSO NACIONAL SOBRE ESSÊNCIAS NATIVAS, 2, São Paulo, 1992. Anais. São Paulo: Instituto Florestal, 1992. p.400-406.

WHITMORE, T.C. An introduction to tropical rain forest. New York: Oxford University Press., 1990. 226p.

WHITMORE, T.C. Gaps in the forest canopy. In: TOMLINSON, P.B. \& ZIMMERMANN, M.H. Tropical trees as living system. Cambrigde: Cambrige Univ. Press., 1978. p.639-655. 
WRIGHT, S.J. \& CALDERON, O. Phylogenetic patterns among tropical flowering phenologies. Journal of Ecology, v. 83, n.6, p.937-948, 1995. 